\title{
The search for organic compounds with TMAH thermochemolysis: From Earth analyses to space exploration experiments
}

\author{
Yuanyuan $\mathrm{He}^{\mathrm{a},{ }^{*}}$, Arnaud Buch ${ }^{\mathrm{a}}$, Cyril Szopa ${ }^{\text {b, c }}$, Amy J. Williams ${ }^{\mathrm{d}}$, Maëva Millan ${ }^{\mathrm{e}, \mathrm{f}}$, \\ Melissa Guzman ${ }^{\mathrm{b}}$, Caroline Freissinet ${ }^{\mathrm{b}}$, Charles Malespin ${ }^{\mathrm{f}}$, Daniel P. Glavin ${ }^{\mathrm{f}}$, \\ Jennifer L. Eigenbrode ${ }^{\mathrm{f}}$, David Coscia ${ }^{\mathrm{b}}$, Samuel Teinturier ${ }^{\mathrm{f}}$, Pin lu ${ }^{\mathrm{g}}$, M. Cabane ${ }^{\mathrm{b}}$, \\ Paul R. Mahaffy ${ }^{\mathrm{f}}$ \\ a Laboratoire Génie des Procédés et Matériaux, CentraleSupélec, University Paris-Saclay, 8-10 rue Joliot-Curie, 91190, Gif-sur-Yvette, France \\ ${ }^{\mathrm{b}}$ LATMOS/IPSL, UVSQ Université Paris-Saclay, Sorbonne Université, CNRS, 11 Bd d'Alembert, 78280, Guyancourt, France \\ ${ }^{c}$ Institut Universitaire de France, Paris, France \\ d University of Florida Gainesville, FL, USA \\ e Georgetown University, Washington D.C., USA \\ ${ }^{\mathrm{f}}$ Space Science Exploration Division (Code 690), NASA Goddard Space Flight Center, Greenbelt, MD, USA \\ ${ }^{g}$ LGPM, CentraleSupélec, SFR Condorcet FR CNRS 3417, Université Paris-Saclay, Centre Européen de Biotechnologie et de Bioéconomie (CEBB), 3 rue des \\ Rouges Terres, 51110, Pomacle, France
}

\section{A R T I C L E I N F O}

Article history:

Available online 20 April 2020

Keywords:

Tetramethylammonium hydroxide (TMAH)

Thermochemolysis

Pyrolysis-GC/MS

Thermally assisted hydrolysis and

methylation (THM)

TMAH degradation

Derivatization

Quantitative analysis

Internal standard

Space experiment

SAM and MOMA

\begin{abstract}
A B S T R A C T
Tetramethylammonium hydroxide (TMAH) is one of the most popular methylation reagents that have been increasingly used for the detection of organic compounds within a wide range of samples, such as soil, coal, lacquer, lignin, polymers and for in situ analysis of solid samples by space experiments. The analytical methods and instruments, experimental conditions, and the qualitative and quantitative analysis of organic compounds using TMAH thermochemolysis for the last 10 years were reviewed; additionally, the mechanism of TMAH thermochemolysis and TMAH degradation are overviewed herein. The objective of this paper is to give a broad view of the TMAH thermochemolysis analysis, to demonstrate how the technique can be used for the detection of organics on Mars and other planets, and to promote cooperation between different disciplines which may use thermochemolysis.
\end{abstract}

(C) 2020 Elsevier B.V. All rights reserved.

\section{Introduction}

\subsection{What is thermochemolysis?}

The analysis of organic compounds is an essential way to detect and demonstrate if there are life signatures in space. Since the early 19th century, it has been hypothesized that there could be lifederived organic matter surviving in the martian soil and randomly distributed across the martian surface over geologic timescales [1]. Extraterrestrial matter and the potential for it to reach the surface of the Earth has been a topic of interest and

\footnotetext{
* Corresponding author.

E-mail address: Yuanyuan.he@centralesupelec.fr (Y. He).
}

debate for centuries. One of the oldest meteorites, which is still preserved today, fell from the sky on November 7th, 1492 and is still on display in the French region of Alsace. Since then, many meteorites have been found to contain soluble organic matter. Subsequent analyses explore how to distinguish a biotic from an abiotic origin for this organic matter [2]. Therefore, the analysis of organics plays a crucial role in the search for life beyond the Earth. Human beings continue to make efforts to explore the universe and search for other habitable planets, even within our own solar system. Today, the Mars Organic Molecule Analyzer (MOMA), an experiment onboard the 2022 ExoMars rover, will search for signs of past or present life on Mars by analyzing the potential organic content in samples collected from up to a two meter depth below the martian surface [3]. 
There are three main methods for analyzing complex and nonvolatile organic compounds. Pyrolysis is a traditional method for analyzing the components of complex materials. Pyrolysis can be performed as slow pyrolysis, which requires a temperature ramp, and fast pyrolysis, in which the sample is heated at a different heating rate at relatively high temperatures in the absence of oxygen. The pyrolysis process, especially at high temperatures, can degrade the main chemical structures of the analyzed materials. Consequently, it is often very difficult to speculate about the initial chemical composition of unknown samples during the analysis of the pyrolysis products. For example, coal pyrolysis is the most traditional way to study the structure and composition of coal and the kinetic rates and mechanisms of coal pyrolysis [4]. Characterization of pyrolysis residues such as char [5] combined with gas releasing properties provide a valuable and comprehensive understanding of coal structure [6]. However, the pyrolysis process is always operated at temperatures higher than $200^{\circ} \mathrm{C}$ and up to about $1800^{\circ} \mathrm{C}[7,8]$, which can destroy the original structure of the sample and produce the char, tar and gas products that are released during coal pyrolysis. Pyrolysis is generally not a good way to conserve the main structure of samples.

Chemical derivatization is another analytical method which can keep intact the main chemical structure of substances by adding a derivatization reagent which reacts with the polar and labile compounds at a relatively low temperature (below $200^{\circ} \mathrm{C}$ ). The derivatization reaction usually involves a substitution of a nonpolar functional group in place of a polar functional group, where the most common reactions are alkylation, acylation and silylation. Alkylation reagents reduce the polarity of the compounds by substituting labile hydrogens for an aliphatic or aliphatic-aromatic (e.g., benzyl) group. Silylation is the most prevalent derivatization technique, and common reagents are trimethylchlorosilane (TMCS), trimiethylsilylimidazole (TMSI), N-methyl-trimethylsilyltrifluoroacetamide (MSTFA), N, O-bis-(trimethylsilyl)trifluoroacetamide (BSTFA) and $N$-(t-butyldimethylsilyl)- $N$ methyltrifluoroacetamide (MTBSTFA). BSTFA and MTBSTFA are most frequently used, particularly when analyzing phenolic compounds, sterols and sugars $[9,10]$. Derivatization methods can be used to reduce the polarity of amino groups to improve their separation and detection by gas chromatography/mass spectrometry (GC/MS). Derivatization reactions of amines by GC were reviewed by Kataoka [11], with respect to reactivity, selectivity and sensitivity, for the application of environmental analysis related to human health. Common derivatization reactions for the GC analysis of amines were presented, including acylation, silylation, dinitrophenylation, permethylation, Schiff base formation, carbamate formation, sulphonamide formation and phosphonamide formation, and the derivatization reactions of different amines were reviewed, including primary amine, secondary amine, tertiary amine, ammonia, and nitrosamine. For volatile and polar compounds, MTBSTFA/DMF is one of the most popular silylation reagents. For the MTBSTFA derivatization reaction, silylation is always performed using mild experimental conditions at low temperatures between $75^{\circ} \mathrm{C}$ and $300^{\circ} \mathrm{C}$ [12], which can result in the replacement of the labile hydrogen atom in an $-\mathrm{OH},-\mathrm{COOH},-\mathrm{SH}$, $-\mathrm{NH},-\mathrm{CONH},-\mathrm{POH},-\mathrm{SOH}$ group or enolizable carbonyl with a silyl group. This reduces the polarity of the analytes, increases their stability, and improves the GC behavior without damaging the main structure of the molecules. However, some refractory materials cannot be detected at low temperature; therefore, derivatization combined with a high temperature environment is needed to obtain important information of certain refractory materials.

Thermochemolysis, or thermally assisted hydrolysis and methylation (THM) in most cases [13], is a type of analytical pyrolysis for in situ characterization of complex samples with a wide range of materials [14]. This method can be tracked back to at least 56 years ago when a study investigated the analysis of fatty acids by GC in the presence of tetramethylammonium hydroxide (TMAH) [15]. The thermochemolysis method is a combination of the analytical techniques of pyrolysis and derivatization. Heat plays a key role in the thermochemolysis process, which facilities the cleavage of the bonds between the main structures at selected chemical bonds of analytes. The reorganization of the analytes' main part and the thermochemolysis functional groups produces the less polar, smaller molecular weight compounds, with higher stability and volatility, which are amenable to chromatographic analysis.

\subsection{Factors influencing thermochemolysis}

\subsubsection{Thermochemolysis reagents}

The reagent plays a key role in the thermochemolysis process. Therefore, thermochemolysis reagents that have been used for the characterization of organic compounds since 2010 have been reviewed, such as TMAH, trimethylsulfonium hydroxide (TMSH) [16,17], tetramethylammonium acetate (TMAAc) [18-20], m-(trifluoromethyl)phenyltrimethylammonium hydroxide (TFTMAH) [21], tetraalkylammonium hydroxides (TAAH) [22] et al. Table 1 lists some of the thermochemolysis reagents that have been used in the detection of organic compounds, mainly fatty acids. TMAH is a relatively strong thermochemolysis reagent with high efficiency in methylation, which is capable of methylating all available active hydrogens from various functional groups, including phenolic hydroxyl groups, carboxylic acids, amines etc. Compared with TMAH, TMSH is a competitive reagent with strong alkaline and heatsensitive properties; however, TMSH requires lower temperature for its alkylation while TMAH can be used at a relatively high temperature up to $600^{\circ} \mathrm{C}$. Therefore, TMAH is one of the most popular thermochemolysis reagents. More than $90 \%$ of published thermochemolysis applications have used TMAH [14], therefore we mainly focus on the properties of TMAH thermochemolysis hereafter.

\subsubsection{TMAH thermochemolysis type (on-line and off-line)}

There are mainly two types of thermochemolysis, off-line and on-line thermochemolysis. In the off-line case, the sample is mixed with a certain amount of TMAH inside some kind of sealed vessel and derivatized for a certain amount of time followed by an analysis by GC-MS. For example, Poerschmann [23] analyzed the organic compounds in the effluent from phytoremediation systems at the laboratory-scale using off-line TMAH-assisted thermochemolysis GC/MS (TMAH-GC/MS). In this study, 15 mg of lyophilized effluent samples was mixed with $2.5 \mathrm{~mL}$ of a $25 \% \mathrm{w} / \mathrm{w}$ freshly prepared TMAH solution in methanol $(\sim 40 \times$ excess TMAH by weight $)$ inside glass ampoules. Next, the open glass ampoule was tightly closed and placed in a steel autoclave, constructed in-house, which allowed the thermochemolysis to take place at $240^{\circ} \mathrm{C}$ for $180 \mathrm{~min}$. Then the sample was analyzed by GC/MS. Carboxylic acids, phenols and the lignin-derived breakdown products were detected, which showed that TMAH thermochemolysis may serve to detect monomolecular organic compounds sorbed onto the root. Tadini [24] studied humic substances extracted from river sediments of northwestern São Paulo which had undergone different soil uses by off-line TMAH-GC-MS and solid state ${ }^{13} \mathrm{C}$ nuclear magnetic resonance (NMR) spectroscopy characterization. In this study, about $100 \mathrm{mg}$ of dried composted organic biomasses was placed in a quartz boat and moistened with $1 \mathrm{~mL}$ of a TMAH (25\% in methanol) solution. The sample was introduced into a Pyrex tubular reactor ( $50 \mathrm{~cm} \times 3.5 \mathrm{~cm}$ i.d.) and heated at $400^{\circ} \mathrm{C}$ for $30 \mathrm{~min}$ in a furnace (Barnstead Thermolyne 21100 furnace) after drying the mixture 
Table 1

Thermochemolysis reagents have been used in the detection of organic compounds.

\begin{tabular}{|c|c|c|c|}
\hline Reagent & Sample & Functional groups & Publications \\
\hline $\begin{array}{l}\text { Tetraethylammonium hydroxide (TEAH); } \\
\text { Tetrabutylammonium hydroxide (TBAH) }\end{array}$ & Wood sample & Fatty acids & [294] \\
\hline Trimethylsulfonium hydroxide (TMSH) & $\begin{array}{l}\text { Soils collected from three different ecosystems } \\
\text { Primary sludge; Water and articulate; } \\
\text { Nexapa River basin samples }\end{array}$ & $\begin{array}{l}\text { Phospholipid fatty acids (PLFAs) } \\
\text { Thiol or polysulfidethiol }\end{array}$ & $\begin{array}{l}{[295]} \\
{[296]}\end{array}$ \\
\hline Tetraethylammonium acetate (TEAAc) & Lignite & Humic acids & [297] \\
\hline Phenyltrimethylammonium hydroxide (TMPAH) & Milk & Fatty acids & [108] \\
\hline $\begin{array}{l}m \text {-(Trifluoromethyl) phenyltrimethylammonium } \\
\text { hydroxide (TFTMAH) }\end{array}$ & Paint samples & Fatty acids & {$[21]$} \\
\hline
\end{tabular}

under a gentle stream of nitrogen for about $10 \mathrm{~min}$. Organic compounds related to the humic acid in the structure were detected by off-line TMAH-GC/MS, including plant waxes, plant biopolyester and a large amount of fatty acid methyl ester. The characterization by NMR provided the carbon nuclei present in the structure, which inferred that the humic acids from an area characterized by sugar cane cultivation (41.9\%) and a typical rural area (35.0\%) showed the highest aromaticity percentage.

Compared with off-line thermochemolysis, on-line or in-situ thermochemolysis is a simpler process that involves mixing the sample with a certain amount of TMAH immediately before injection of the sample into the GC instrument. This process avoids laborious and time-consuming sample work-up steps and allows us to conduct the reaction efficiently only by mixing the specimen and reagents [25]. The on-line TMAH thermochemolysis technique is able to control the reaction temperature easily and reaction time with efficient transfer of volatiles to GC/MS analysis system. These advantages ensure the high efficiency of TMAH thermochemolysis. Therefore, on-line TMAH thermochemolysis has been widely used in the characterization of a variety of natural and synthetic materials. It showed a good performance during the analysis of methylated lignin phenols and other from the rivers derived sediments [26], compounds of asphaltene biodegradation [27], lacquer compositions [28], model compounds guaiacyl palmitate and 2-nonyl palmitate [29], etc. For example, Mason [30] studied the molecular composition of grassland soil with adjacent unforested and afforested moorland ecosystems using on-line thermally assisted hydrolysis and methylation in the presence of both unlabelled and ${ }^{13} \mathrm{C}$-labelled TMAH. During the thermochemolysis experiment, an aqueous solution of TMAH and ${ }^{13} \mathrm{C}$-labelled TMAH $(25 \%, \mathrm{w} / \mathrm{w})$ were added into a quartz pyrolysis tube plugged with pre-extracted silica wool containing approximately $2 \mathrm{mg}$ of sample immediately prior to thermal hydrolysis and methylation. The ${ }^{13} \mathrm{C}$-labelled TMAH thermochemolysis revealed the chemical composition of soil organic matter (SOM) and reflected the different vegetation inputs in each of the chemicals associated with a litter/fermentation (L/F) layer.

In addition, off-line thermochemolysis is able to detect more compounds, because of the longer retention time compared with on-line thermochemolysis, thus the recovery rate of off-line thermochemolysis is better than on-line thermochemolysis in some cases. However, the long reaction time such as $\mathbf{3 0}$ min could cause the rearrangements and decompositions of amino acids [25]. The off-line thermochemolysis requires several steps, including the solvent derivatization, extraction and the evaporation of the solvent. These processes are too technically complex to be fully automated for the in situ analysis in space missions, especially in the detection of organic compounds on Mars. Therefore, a simpler "on-line" thermochemolysis method has been implemented for SAM and MOMA [31], thanks to the advantage of being able to control the reaction temperature and reaction time with efficient transfer formed thermochemolyzates to GC/MS system.

\subsubsection{Sample pre-treatment methods}

Direct thermochemolysis is the simplest way to derivative samples; it does not need any cumbersome sample pretreatment, only mixing the sample with derivatization regent immediately followed by the analysis process. In our previous study, the nucleobases standard samples were characterized by TMAH direct thermochemolysis [31], without any pretreatment. Though without any tedious pretreatment, direct thermochemolysis could have a sufficient accuracy and efficiency. Baidurah's team [32,33] compared the effect of direct thermochemolysis with conventional method with extraction pretreatment of bacterial samples. Through analyzing the yield of characteristic peaks of polymers from bacteria, direct thermochemolysis showed a good performance as the conventional method with sample pretreatment process. However, in addition to the direct thermochemolysis, two pre-treatment processes prior to thermochemolysis could be used in the laboratory: extraction and mineralization, especially for solid matrix such as soils, kerogens, meteorites etc.

Extraction: Extraction is a separation process in which substances are separated from a solid or liquid matrix. This type of separation process mainly includes liquid-liquid extraction and solid-liquid extraction, and the solid-phase extraction. The first experimental application of solid-phase extraction started 50 years ago and is the most frequently used procedure for extraction of a wide range of organic analytes across many fields [34]; such as the extraction of fatty acids in bilayer oil paint models [35], of carbohydrates, lignin and lipids from peat bog or soil [36-39], of sputum specimen [40,41], of organic mercury species in petroleum [42], of the amino, carboxylic, and nucleic acids from martian analog samples [43-45], of iodine from environmental samples [46,47], of trace elements from soil environmental matrices [48], of free small molecules from coal [49-51], of humic substances from lignocellulose waste [52], etc. Solid-phase extraction is faster and less labor intensive than the liquid-liquid extraction and only requires smaller volumes of reagents, generating less toxic waste and producing better analyte enrichment factors [34]; because of these advantages of the solid-phase extraction, it has been widely used for the analysis of soot from the combustion of fossil fuels and synthetic biofuels [53], drugs in waste water [54], etc.; isolate bisphenol A in urine [55], food analysis such as the extraction of ochratoxin A from red wines [56], botanic and marine applications, etc. For the in situ analysis of organic compounds that could possibly be detected in other surface environments such as that of Mars, solid-phase extraction is the optimal method for the characterization of that soil.

Recently, in order to comprehensively analyze the organics in solid samples such as soil, fossils [57], coal, and wood, some pretreatments were used. Extraction has been one of the most popular pre-treatment techniques for solid sample analysis, which could include a sequential extraction of samples by different extraction solvents. For example, Allard [58] characterized the organic matter 
from a forest soil using sequential microwave assisted acid and TMAH hydrolysis at $190^{\circ} \mathrm{C}$. The solvent extraction included hydrogen chloride/acetonitrile $(\mathrm{HCl} / \mathrm{MeCN}), \mathrm{H}_{2} \mathrm{O}$, and ethyl acetate (EtOAc) extraction. The different extracts were also derivatized by different reagents. Organic or aqueous extracts were analyzed by $\mathrm{GC} / \mathrm{MS}$; the residue was characterized by the solid state ${ }^{13} \mathrm{C}$ nuclear magnetic resonance (NMR) spectroscopy. Aromatic compounds are the main component of the organic extractions. Microwaveassisted acid hydrolysis provided information about hydrophilic constituents and unaltered lignin-derived constituents of SOM. Microwave-assisted TMAH hydrolysis released predominantly aliphatic compounds from cutin and suberin.

Demineralization: Demineralization is a process in which different acids are used to remove the mineral that is tightly associated with organics in the solid matrix. For example, demineralization processes have been used to improve the efficiency of extraction and characterization of organic matter from soil/kerogen $[59,60]$. The solvent varies depending on the mineral that will be removed; normally water can remove the alkali and alkaline earth metals, while $\mathrm{HCl}$ and hydrogen fluoride (HF) can be used to remove the inherent minerals from coal [61]. HF media for demineralization treatment of soil samples were also used for organic analysis. This technique allows the demineralization of three kinds of agricultural soils followed by TMAH-GC/MS [62]. Results showed that the clay removal provided by HF pretreatment can improve the capacity of TMAH thermochemolysis. Doskočil [50] obtained a similar result when they studied the pyrolysis process of South Moravian lignite in its natural and treated forms, including extraction with chloroform, demineralization, and the remineralization or sorption of calcium ions on the demineralized lignite. TMAH thermochemolysis was also used to analyze the component of lignite. Results demonstrated that the highest yields of the aliphatic molecules were obtained in the case of demineralized lignite, which could be caused by the cracking of carboxylic groups between calcium bridges and functional groups during the demineralization process. Additionally, the Fourier transform infrared spectroscopy (FTIR) and TG-FTIR were also used to analyze the pyrolysis products in solid and gaseous states, respectively.

Extraction could increase the concentration of target compounds in a sample and improve the efficiency of sample analysis; therefore, when the organic compounds are in low abundance or the individual compounds need to be analyzed separately, the sequential extraction technique should be used; when the minerals in the sample could affect the detection of organic compounds, the demineralization process should be used to remove different minerals by using different reagents.

\subsubsection{Experimental conditions}

Experimental conditions such as the temperature of thermochemolysis, the $\mathrm{pH}$ of the sample, and the amount of solvent influence the efficiency of TMAH thermochemolysis. The optimal temperature varies with the sample and the compounds that need to be derivatized. Decq [63] analyzed European lacquer and optimized the thermochemolysis temperature $\left(350,480,550,650^{\circ} \mathrm{C}\right)$ of natural resins, including Sandarac, Mastic, Colophony, Manila copla, and Congo copal. Results showed that $350^{\circ} \mathrm{C}$ is the optimal thermochemolysis temperature for natural resins and that $550^{\circ} \mathrm{C}$ is the second most optimal temperature. Polycommunic acid markers "b1" and "b4", Pimaric acid, and the poly-ozic marker were used as the markers of Sandarac, Colophony, and Congo copal, respectively. For nucleobases, we found $600^{\circ} \mathrm{C}$ is the optimal temperature for TMAH thermochemolysis combined with Pyrolysis-gas chromatography and mass spectrometry (TMAH-Py-GC/MS) [31]. The amount of TMAH could also influence the thermochemolysis result $[31,64]$. For example, TMAH concentration or $\mathrm{pH}$ values can cause the conversion of aliphatic model compounds [65], such as succinic, adipic, and azelaic acid, into diesters. At a sample $\mathrm{pH}$ of $7-8$, the ester yield is the highest around $90 \%$; however, at a higher $\mathrm{pH}$ value $(>10)$, the methylation process can be negatively affected. TMAH is a strong thermochemolysis reagent which remains fully functional after exposure to a total ionizing dose (TID) up to $300 \mathrm{krad}$, with a post-exposure, GC/MS analysis showing no or few degradation products of the chemicals [12]. This result is very important for in situ space analyses where reagents can be exposed to high radiation doses. In addition, the minerals such as perchlorate and other oxyanion salts of soils and meteorites could possibly influence the type and numbers of organic compounds [66], though few researchers studied the influence of minerals on TMAH thermochemolysis. Therefore, plenty of experimental conditions of SAM and MOMA need to be studied in the future.

\subsection{Set-ups for thermochemolysis and complementary technologies}

Py-GC/MS is the main device used for TMAH thermochemolysis, or namely reactive Pyrolysis-GC/MS [18,67-69], because the technique can provide precise information about the molecular formula and the structures of compounds. Commercial pyrolysis devices have been used in studies conducted over the past 10 years, such as a Curie-point [70-77], a CDS type pyrolyzer [78-81], a microfurnace pyrolyzer $[17,19,31,82-87]$, and a tubular oven [50,51,62,88-91]. Commercial GC/MS is used for the separationdetection of samples after thermochemolysis. The GC column plays a key role in the separation of volatiles, so different kinds of columns have been used, including fused silica capillary columns [70,75,88], HP-5 columns [79,92-96], Rtx-5Sil MS columns $[62,72,89-91,97,98]$, and SLB 5MS capillary columns [82,83,99]. The type of column is the first and one of the most important steps to obtaining the optimal conditions in the analysis of organic compounds by using GC/MS. Selecting the column depends on four factors, including the stationary phase, the column inner diameter, the membrane thickness, and the column length, with the stationary phase being the most important factor. Because TMAH is aggressive, the resistance of the stationary phase toward the TMAH is another factor that we have to take in account. SLB 5MS capillary columns with a $5 \%$ phenyl equivalent phase provide a boiling point elution order with a slight increase in selectivity, especially for aromatic compounds. The low bleed characteristics and durable nature make it the column of choice for any experiment in which a low bleed non-polar column is required. The Rtx-5Sil MS column, a low polar column, is appropriate for the analysis of amines, anesthesia analysis, Crossbond ${ }^{\mathrm{TM}}$, organochlorine pesticides, phenols, and phthalates. The HP-5 column has a wide range of applications since it is a high-performing non-polar column available in a variety of configurations, especially for active compounds including acidic and basic compounds.

Sawicka [100] investigated the removal of visually disturbing lead soap efflorescence with ethylenediaminetetraacetic acid (EDTA), and optimized conditions such as $\mathrm{pH}$, concentration of EDTA solution and application. The result showed that it is feasible to thin the superficial material significantly. A combined method of ATR-FTIR and SEM-EDX analysis coupled to TMAH thermochemolysis were used. In this study, the TMAH was used as a kind of derivatized solvent and two kinds of internal standards $\left(C_{13}\right.$ and $C_{23}$ fatty acids) were used. The lead stearate, lead palmitate and mineralized lead soap are the predominant components. Barden [101] studied a tadpole from the Oligocene Enspel Formation in Germany using the Py-GC/MS technique combined with TMAH thermal methylation of the fossil tadpole matrix, in addition to FTIR. Results showed that the organic remains of the tadpole are original and are not the result of external contamination. The Py- 
GC/MS analyses indicate the presence of bacterial biomarkers in the matrix but not the tadpole. SRS-XRF also has been used to analyze the levels of zinc. Table 2 lists all of the devices that have been used as a complementary method with TMAH thermochemolysis.

\section{Applications}

Since TMAH is one of the most popular thermochemolysis reagents [14], the studies about TMAH thermochemolysis have been reviewed for its application on the analyses of humic acids [52,84,90,102,103], humic-like substances [104-107], fatty acids [82,88,102,108], phenolic compounds [16,19,81,109], amino acids [64,110], aromatic and aliphatic compounds [29,111], and carbamates [112]. In addition, TMAH is not only a thermochemolysis reagent but is also used as an effective silicon etching solvent [113-115], for dissolution of E. crypticus [116], as a strong base catalyst for transesterification [117], as an extraction solvent for mercury [42,118-121], and Sulfur atom detection [17,122], as a dispersant [123], as a balance-fluid in the fabrication of functionalized-porosity layered-ceramics processes [124], as a digestion solvent for biological samples [125,126], for $\mathrm{pH}$ adjustment of solutions [127,128], and for extraction of different halogen elements in soils, such as fluorine [129], chloride [130,131], bromine [132,133], and iodine [134-137]. The detection of iodine can be useful for two main types of applications; the first, measurements of the concentration and distribution of iodine in soils
[138-140], and the transference of iodine in different forms between soils and plants [141-146], as well as foods [147,148], have been combined with characterization by inductively coupled plasma mass spectrometry (ICP-MS). The second main application is to detect the concentration of iodine and related compounds in a contaminated environment [149-152]. For example, Yang [46] studied rapid iodine release from soil, sediments, and rock samples through mild TMAH extraction. The ${ }^{127} \mathrm{I}$ concentration was analyzed by the triple-quadrupole inductively coupled plasmamass spectrometry (ICP-QQQ) single MS mode and the ${ }^{129} \mathrm{I} /{ }^{127} \mathrm{I}$ ratio was analyzed by the ICP-QQQ MS/MS mode. TMAH is also a major problem for wastewater [153], and could be degraded by biological treatment in an up-flow anaerobic sludge blanket (UASB), mainly the methanogens involved in methanogenic degradation of TMAH [153-155]. Hereafter we mainly focus on the application of TMAH thermochemolysis.

\subsection{Lignin and plants}

Lignin, the second most abundant terrestrial polymer on Earth after cellulose, and the only large-volume renewable feedstock composed of aromatics, is an essential raw materials for the polysaccharides, renewable source of fuels, functional polymers, materials, and aromatic chemicals such a phenol, vanillin, and ferulic acid [156,157]. Lignin is a complex heterogeneous biopolymer mainly constructed out of three oxidative $p$-hydroxycinnamyl

Table 2

Combined analyses methods with TMAH-thermochemolysis.

\begin{tabular}{|c|c|c|c|}
\hline Analysis & Instruments & Analysis goal & Publications \\
\hline \multirow[t]{2}{*}{ Thermal analysis } & $\begin{array}{l}\text { Pyrolysis-gas chromatography and mass } \\
\text { spectrometry (Py-GC/MS) }\end{array}$ & $\begin{array}{l}\text { Heat samples (flash pyrolysis or slow pyrolysis) and } \\
\text { get volatiles, these volatiles were swept into GC and } \\
\text { detected by MS }\end{array}$ & $\begin{array}{l}{[17,24,29,57,71,73,74,84,87,92,99,102,} \\
158,166,173,176,181,185,199,210,211,215, \\
251,252,266,274,298-303]\end{array}$ \\
\hline & $\begin{array}{l}\text { Thermogravimetric analyzer - mass } \\
\text { spectrometry (TGA-MS) }\end{array}$ & Slow pyrolysis and fragments detection & {$[50,52,214,238]$} \\
\hline \multirow[t]{2}{*}{ Separation } & Gas chromatography (GC) & Separation of mixtures & {$[304,305]$} \\
\hline & $\begin{array}{l}\text { High performance liquid chromatography } \\
\text { (HPLC) }\end{array}$ & $\begin{array}{l}\text { Separate, identify, and quantify each component in } \\
\text { a mixture }\end{array}$ & {$[301,306]$} \\
\hline \multirow[t]{10}{*}{ Chemical structures } & $\begin{array}{l}\text { liquid chromatography -mass spectrometry } \\
\text { (LC-MS) }\end{array}$ & $\begin{array}{l}\text { Separation of mixtures and organic compounds } \\
\text { detection }\end{array}$ & [299] \\
\hline & $\begin{array}{l}\text { Direct temperature resolved mass spectrometry } \\
\text { (DTMS) }\end{array}$ & Chemical composition of a broad range of materials & {$[224,229,307,308]$} \\
\hline & $\begin{array}{l}\text { Matrix Assisted Laser Desorption Ionization- } \\
\text { Time of flight-mass spectrometry (MALDI-TOF } \\
\text { MS) }\end{array}$ & $\begin{array}{l}\text { Sensitive detection of large, non-volatile, labile } \\
\text { biomolecules }\end{array}$ & [309-311] \\
\hline & $\begin{array}{l}\text { Inductively coupled plasma mass spectrometry } \\
\text { (ICP-MS) }\end{array}$ & Binder characterization in artistic samples & $\begin{array}{l}{[83,119,121,135,137,139,147} \\
150,217,312-320]\end{array}$ \\
\hline & $13 \mathrm{C}$ nuclear magnetic resonance (13C NMR) & Chemical structure of $\mathrm{C}$ & {$[72,78,86,97,105,107,176,238,298,321,322]$} \\
\hline & 2D nuclear magnetic resonance (2DNMR) & $\begin{array}{l}\text { Characterize the structure of molecular components } \\
\text { and functional groups in humic matter }\end{array}$ & [323] \\
\hline & H nuclear magnetic resonance (H NMR) & Chemical structure of $\mathrm{H}$ & {$[324,325]$} \\
\hline & Raman spectroscopy & $\begin{array}{l}\text { Identify molecules and study chemical bonding and } \\
\text { intramolecular bonds }\end{array}$ & {$[214,299,326,327]$} \\
\hline & Fourier transform infrared spectroscopy (FTIR) & Chemical functional groups & {$[50,52,99,105,173,215,298,299,324-337]$} \\
\hline & Total organic carbon analysis (TOC) & Total organic carbon content for soil analysis & {$[135,241,338]$} \\
\hline \multirow{9}{*}{$\begin{array}{l}\text { Surface or crystal } \\
\text { structures }\end{array}$} & Fluorescence spectrometry (XRF) & Mineral composition & {$[99,211,330,339]$} \\
\hline & $\mathrm{X}$-ray diffraction (XRD) & $\begin{array}{l}\text { Study the structure, composition, and physical } \\
\text { properties of materials }\end{array}$ & {$[215,241,335]$} \\
\hline & X-ray photoelectron spectroscopy (XPS) & $\begin{array}{l}\text { Surface properties and chemical state of modified } \\
\text { catalysts }\end{array}$ & {$[72,107,241,328]$} \\
\hline & Light microscopic (LM) & Examination of small objects & {$[229,299]$} \\
\hline & Photography & $\begin{array}{l}\text { Visible and ultraviolet-induced visible fluorescence } \\
\text { images }\end{array}$ & [215] \\
\hline & Transmission electron microscopy (TEM) & Image of the micro structure of sample & {$[328,335]$} \\
\hline & Scanning electron microscope (SEM-EDX/EDS) & $\begin{array}{l}\text { Elemental analysis or chemical characterization of a } \\
\text { sample }\end{array}$ & $\begin{array}{l}{[211,221,229,299,301,328,330,} \\
331,333,340]\end{array}$ \\
\hline & $\begin{array}{l}\text { Fluorescence spectrum by 3DEEM } \\
\text { spectrofluorometer }\end{array}$ & $\begin{array}{l}\text { Direct quantification of Effluent Organic Matter } \\
\text { (EfOM) fractions }\end{array}$ & [238] \\
\hline & $\begin{array}{l}\text { Microfade testing electron paramagnetic } \\
\text { resonance spectroscopy (MFT) }\end{array}$ & $\begin{array}{l}\text { Direct lightfastness testing on objects or minute } \\
\text { samples from objects }\end{array}$ & [341] \\
\hline
\end{tabular}


alcohol monolignols differing in their degree of methoxylation, such as p-coumaryl, coniferyl, and sinapyl alcohols. Each of them gives rise to a different type of lignin unit named $p$-hydroxyphenyl $(\mathrm{H})$, guaiacyl (G) and syringyl (S) units, respectively [158]. Lignin is a highly aromatic cell-wall polymer typical of vascular plants that is of importance during the growth and development of the plant and for pathogen protection, meaning lignin provides structural support to woody and vascular plants and is believed to account for ca. $20 \%$ of the organic matter input to the biosphere $[159,160]$. On the other hand, lignocellulosic biomass is a sustainable source of organic carbon that is a valuable feedstock for the production of biofuels and materials [160]. Because of its availability and the variety of potential modifications offered by its chemical nature, lignin has long been attractive for many scientists. However, the recalcitrance of lignocelluoses associated with lignin is an obstacle for the utilization of lignin. Therefore, pretreatment and delignification is very important. There are two types of lignin depolymerization, chemical and biological delignification, which can be used to analyze degradation products of lignin as a way to characterize the depolymerization process. Examples include the analysis of lignin degradation products from white-rot basidiomycete fungi [80], rown rot fungi Gloeophyllum trabeum and Postia placenta [161], beetles [162], and termites [163].

Py-GC/MS and TMAH thermochemolysis is often used to analyze organic compounds released from the degradation of lignocellulosic biomass. The process of pyrolysis in the presence of TMAH avoids decarboxylation and releases intact methylated phenolic compounds [158]. Therefore, this method has been widely used for the analysis of the structure of lignin in various plants. For example, Kaal [164] analyzed the main compositions of plant organs of $P$. oceanica and the coarse organic matter from a mat core spanning 750 yrs using Py-GC/MS and TMAH (25\% in water) combined with THM-GC/MS in order to improve our understanding of the molecular properties and their preservation during mat development. Results showed that constituents based on $p$-hydroxybenzoic acid ( $p$-HBA) are the main component of leaf sheaths, roots and the outer parts of rhizomes. The inner rhizome and leaf blades are mainly composed of carbohydrates. Additionally, the changes in molecular composition of Posidonia australis sheaths $(\mathrm{SH})$ and roots plus rhizomes (RR) along a sediment core were studied by using ${ }^{13} \mathrm{C}$ NMR, TMAH-Py-GC/MS [165]. Marques [166] studied the structure of lignin and suberin and ferulic acid in cork from Quercus suber L. The polymer structure in cork, corksap, and milled-cork lignins (MCL) was studied by TMAH-Py-GC/MS and heteronuclear single quantum coherence spectroscopy (2D-HSQC-NMR). Results showed that the suberin contained $94.4 \%$ aliphatics and $3.2 \%$ phenolics with $90 \% \omega$-hydroxyacids and $\alpha, \omega$-diacids. There is about $3 \%$ and $6 \%$ of ferulic acid in cork and cork lignin. The cork lignin is essentially a G-lignin with more than $96 \%$ G units, the structure of which is largely dominated by $\beta-0-4^{\prime}$ alkyl-aryl ether linkages.

Through the Py-GC/MS method combined with TMAH thermochemolysis, lignin is decomposed into different fragments. The main structures present in different plants are summarized in Fig. 1. Based on these structures present in lignin, TMAH thermochemolysis could be used for the detection of byproducts coming from the degradation of lignin $[80,158,167,168]$. Lignin degradation can occur in leaves, needles, roots, the extracts from wood, sporollenin [39,169-173], and leaf and needle litter. Some of these byproducts, such as the phenolic compounds and fatty acids coming from lignin degradation [37,174-178], have been quantified by using ${ }^{13} \mathrm{C}$ labelled TMAH thermochemolysis [39,169,179]. For example, in situ TMAH-Py-GC/MS was used to study the lignocellulosic unlocking mechanism for carbohydrate hydrolysis in termites [163], which is able to characterize the product distribution between the control and the termite feces, and results indicated dehydroxylation and modification of selective inter-monomer side-chain linkages in the lignin in the termite feces. Later, the wood metabolites in each gut segment were tentatively analyzed using TMAH-Py-GC/MS [180], which showed a selectivity of $\beta-0-4$ ' linkages and subsequent methylation of all ring hydroxyls that were represented by the generation of abundant new pyrolyzates. This study helps to provide more information about the absolute structure change of lignin compared with a normal pyrolysis analysis. On the other hand, the stepwise lignin unlocking mechanism in termites was elucidated. The changes in lignin composition or structure could provide information to understand the reaction in nature; for example, the analysis of compositional changes of lignin in river samples could help to increase understanding of the responses of terrestrial vegetation in central Japan to global climate changes [77]. The study of lignin fractions isolated previously by sequential enzymatic hydrolyses using Py-GC/MS, with and without TMAH thermochemolysis, could help to well understand the behavior of the polymeric part of lignin exposed to fecal microbiota [181] and the molecular changes of corn stover lignin in the laccase system by comparing the methylated fractions of lignin [182].

For plants, suberin and suberan are the important natural biopolymers. Their role is to provide a protective barrier between the plant and the environment [183]. The structure of this hydrolysable polyester is proposed to be comprised of long chain $\left(C_{11}-C_{24}\right)$ polymethylenic domains with carboxylic acids held together by aromatic rings and esters [184]. Olivella [183,185] analyzed the suberin monomers isolated from cork by TMAH-Py-GC/MS. Their study showed that the major compounds of suberin from back and cork layers were octadec-9-enedioic acid, docosanedioic acid, and 9,10 -epoxyocta-decanedioic acid with mean values of $17.0 \%, 14.5 \%$, and $11.0 \%$, respectively. These isolated monomers were used to study the sorption of three pesticides (isoproturon, methomyl and oxamyl), and modeling calculations was used to study the interaction between the suberin monomers. Results showed that, in addition to the van der Waals interactions with the apolar region of sorbent and isoproturon, hydrogen bonds were also formed between the isoproturon $\mathrm{NH}$ group and a carboxylic oxygen atom of a suberin monomer.

We showed here that TMAH thermochemolysis was mainly used to analyze phenolic, ester, ether bonds and carboxyl functional groups of lignin, as well as their related degradation compounds, which demonstrates its suitability for the determination of the composition of large polymers. Soil is the necessary condition for plant, leaves, stem, roots or other organs of plants that are contained in soils, therefore TMAH thermochemolysis could also be used to analyze the degradation compounds of lignin or compounds derived from lignin in soil.

\subsection{Coal}

Coal is a kind of flammable sedimentary rock in black or brownblack color, which is predominantly of vegetal origin. Lignin is possibly the most important vegetal precursor of vitrinite in coal in terms of quantity; monocyclic aromatic units are condensed with the aliphatic lignin forming polycyclic aromatic units, such as naphthalene, anthracene, or phenanthrene through the coalification process [186]. Fig. 2 shows the structural model of high-volatile bituminous coal. Coal has a macromolecular three-dimensional cross-linked network (immobile phase) with a multitude of relatively small molecules with varying structures embedded therein (mobile phase). Coal has been widely used in many fields. For example, coal has been the main energy source for power generation in China. Coal char is used in the metallurgical industry, while coal tar is used to refine oil to different quality grades, such as the heavy oil used for aircraft oil and the light oil used in chemical 


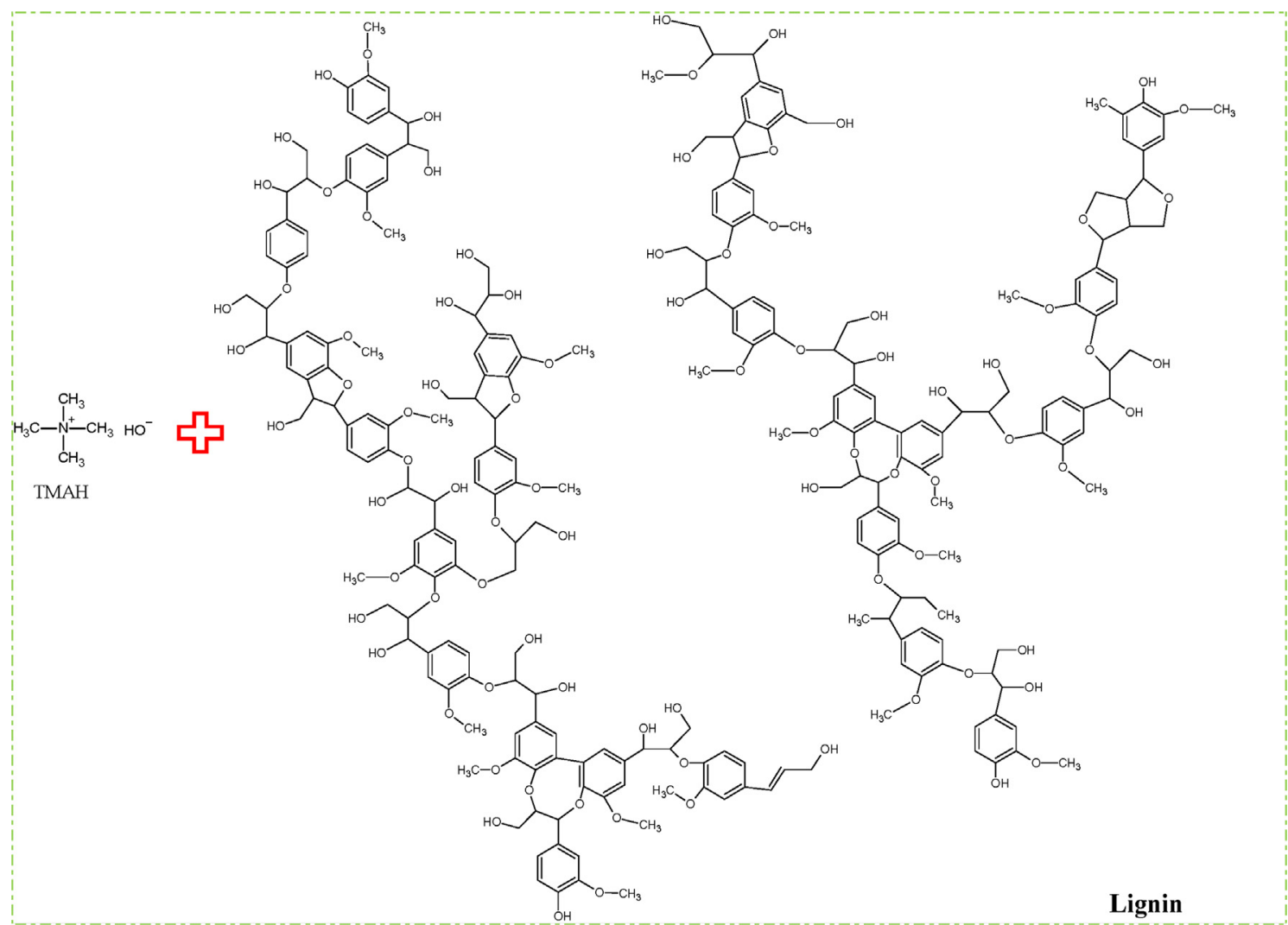

Lignin

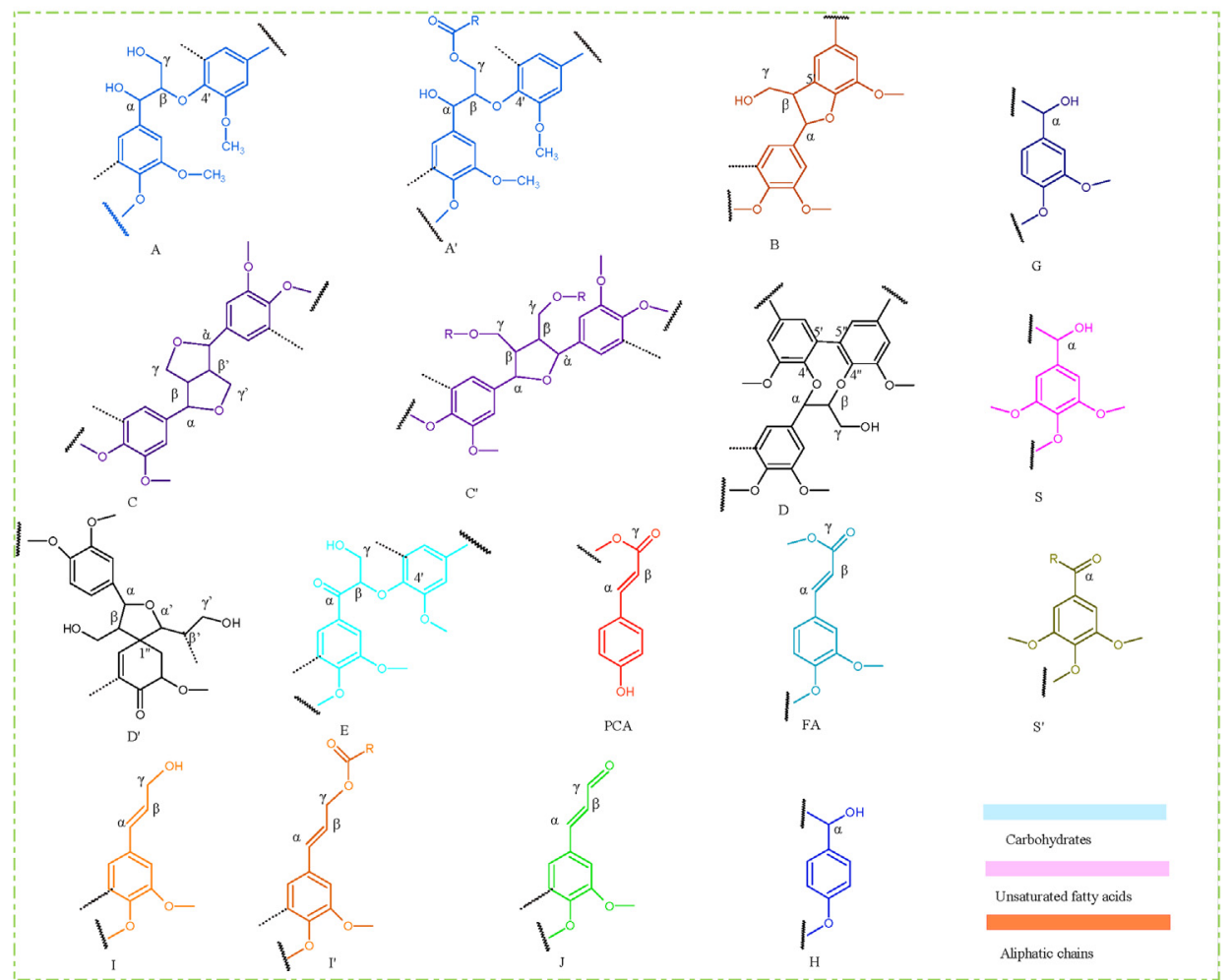

Fig. 1. The structures of lignin that react with TMAH thermochemolysis, adapted from Ref. $[158,160,166,362,363]$. (A) $\beta-0-4^{\prime}$ alkyl-aryl ethers; (A') $\gamma$-acylated $\beta-0-4^{\prime}$ alkyl-aryl ethers; (B) phenylcoumarans; (C) resinols; ( $\left.C^{\prime}\right)$ tetrahydrofuran structures formed by $\beta-\beta$ coupling of monolignols acylated at the $\gamma$-carbon ; (D) dibenzodioxocins; ( $D^{\prime}$ ) spirodienone structures formed by $\beta-1^{\prime}$ coupling; (E) C $\alpha$-oxidized $\beta-O-4^{\prime}$ structures; (I) cinnamyl alcohol end-groups; (I') $\gamma$-acylated cinnamyl alcohol end-groups; (J) cinnamyl aldehyde end-groups; (PCA) p-coumarate units; (FA) ferulates; (H) p-hydroxyphenyl units; (G) guaiacyl units; (S) syringyl units ; ( $\mathrm{S}^{\prime}$ ) oxidized syringyl units bearing a carbonyl (R, lignin side-chain) or carboxyl (R, hydroxyl group) group at $\mathrm{C} \alpha$. 


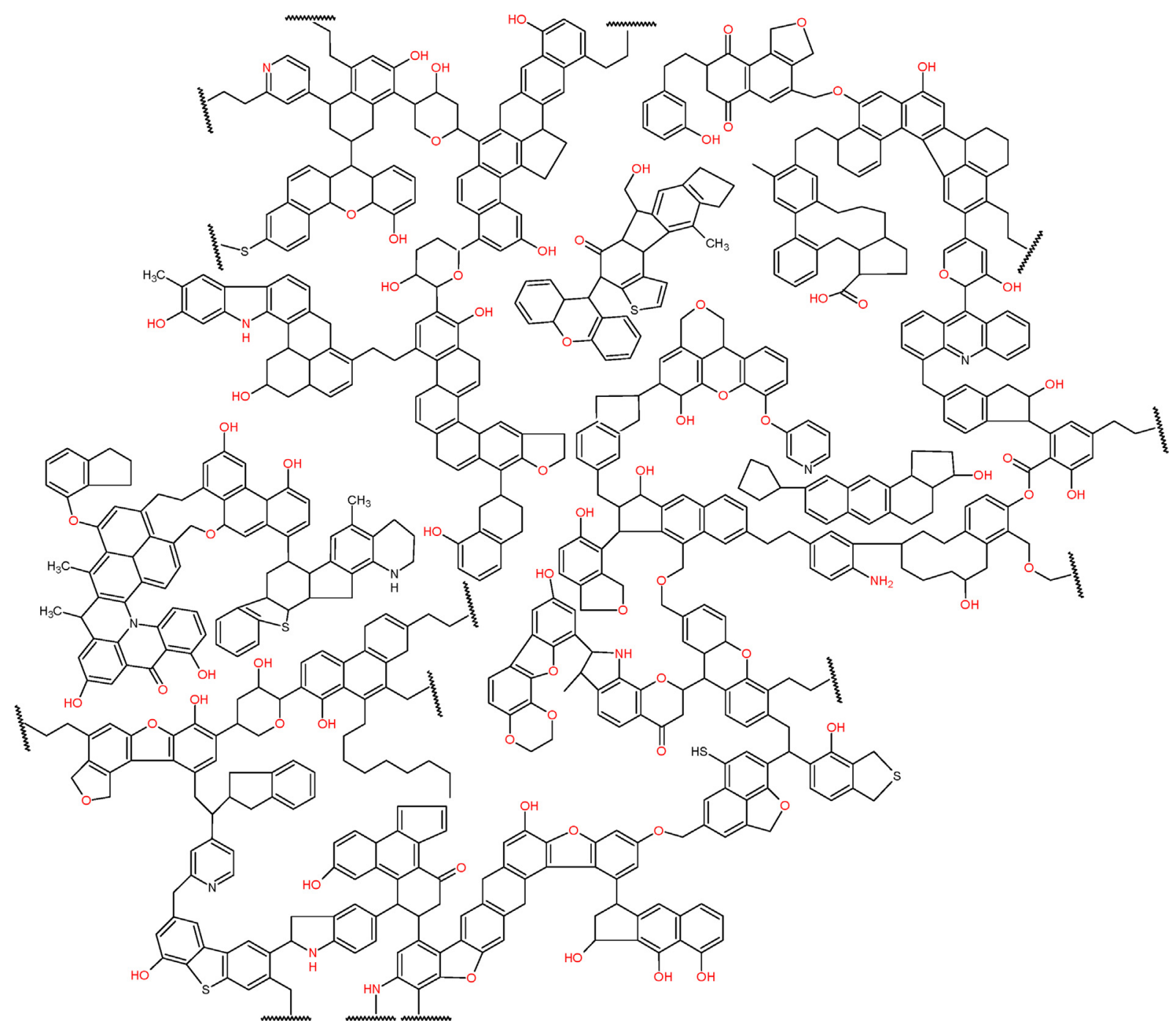

Fig. 2. The structure of bituminous structure, adapted from [194].

products. Light oils include the light aromatic compounds, such as benzene, toluene, ethylbenzene, xylene and naphthalene. All these light aromatic compounds are important raw materials for chemical products, such as fibers, plastics, pharmaceuticals, dyes, and other chemicals [187]. Coal gasification is a means to covert fossil fuels into a combustible gas or a synthesis gas, and this process plays an important role in the green energy conversion of coal into natural gas. Therefore, coal is one of the most important energy sources except for petroleum.

The conversion rate of coal into "clean" energy depends on the utilization methods and the properties of coal. In fact, the structure of coal determines the conversion and utilization method, and plays an important role in the utilization of coal. Coal structure and the main organic matters of coal have been studied using XRD, ${ }^{13} \mathrm{C}$ NMR, Raman, and FTIR spectroscopy. Organic matters, such as low molecular weight compounds, can be extracted from coal by organic solvents $[49,188]$. Pyrolysis GC/MS combined with extraction methods can result in the formation of light aromatics $[189,190]$. Although these are the traditional methods, TMAH thermochemolysis has become an increasingly popular method for characterization of organic matter in coal. For example, TMAH-GC/ MS was used to analyze the composition of filtrate coal after coal depolymerization [191]; identified compounds included fatty acids and derivatives, benzene related O-containing compounds, alcohols, heteroatom containing compounds, hydrocarbons, aromatics, and dicarboxylic acids.

Coal is composed of some macromolecular structures as shown in Fig. 2. Humic acids, complex compounds containing hydroxyl and phenolic hydroxyl functional groups, are one of the important components of coal, and TMAH thermochemolysis has been used for the analysis of humic acids. For example, Grasset [192] characterized the lignin monomers in low rank coal humic acids using TMAH thermochemolysis followed by reductive cleavage. Results showed that the lignite (low rank coal) from the Czech Republic contains intact lignin monomers with a dominance of coniferyl units, which is in accordance with the gymnosperm origin of the lignite. The major methylated lignin derivatives included 3,4dimethoxybenzaldehyde, 3,4-dime-thoxyacetophenone and a 3,4dimethoxybenzoic acid methyl ester. Nasir [193] also studied the structure of humic acids and nitrohumic acids (NHA) extracted from Pakistani lignite as well as the standard leonardite humic acids (LHA) using Py-GC/MS with and without TMAH thermochemolysis and with a flash pyrolysis temperature of $721^{\circ} \mathrm{C}$. In addition, the FTIR and NMR techniques were used to elucidate the influence of coal rank on the regeneration and nitration processes related to the chemical composition of coal and derived materials. 
The most abundant aromatic derivatives were a 4benzenedicarboxylic acid dimethyl ester and 1,6,7-trimethyl naphthalene. A high proportion of long-chain fatty acid methyl esters, nitrogen compounds and furan compounds were detected.

Extraction of organic matter from coal is a crucial method to first separate the free small molecules, including the aliphatics, and ether bridges within the skeleton structure of coal [49,194]. The organic compounds in coal extracts and extraction residues can then be studied combined with TMAH thermochemolysis. Stefanova [195] analyzed the components of $\mathrm{CHCl}_{3}$ extraction residues of bitumen coal by using off-line TMAH-Py-GC/MS where the sample was pyrolysed at $400^{\circ} \mathrm{C}$. Diterpenoids, $n$-Fatty acids, phenols and its alkylated homologues were detected. The long-chain homologues of $n C_{24}$ and $n C_{26}$ were maximal in the bitumen coal used herein; their results demonstrated that the predominance of conifers in the Bobov dol palaeomire was the biomarker assemblage of the "free" extractable bitumen [195]. The extracted component of the coal sample was influenced by the extraction solvent. Doskočil [51] studied the water-extractable fractions from South Moravian lignite, and results showed that the main contents of the off-line TMAH thermochemolysis of lignite were aromatic compounds ( $77 \%$ of the total identified molecules), such as benzene carboxylic acids and their derivatives, especially methoxybenzoic acids, and to a lesser extent, methoxybenzenes. The identified aliphatic compounds consisted of short-chain diacids, fatty acids and polyols and were $23 \%$ of the identified compounds. Py-GC/MS can provide more insights into the chemistry of the resin-derived material, while THM-GC/MS is more informative about polymethylene compounds. The two methods are complementary for detecting the aryl- $\mathrm{O}$ macromolecular backbone of kerogen. On the other side, the maturity of coal also influences the content and the type of its organic matter. The effect of coal rank on coal molecular properties has been investigated using 27 coal samples from lignite to high volatile bituminous rank using Py-GC/MS and THM-GC/MS methods [196]. Polyphenolic, polymethylenic and resin-derived constituents were detected. Lignin-derived material and longchain $(\geq \mathrm{C} 24)$ ester-bound polymethylene chains are the main components of immature coal, whereas the mature coals are enriched in short (C10-C25) free and/or trapped (isoprenoid) hydrocarbons, alkylated phenols and resinite aromatic derivatives.

Biodegradation or bioconversion of coal is a valuable form of clean energy conversion. In one study, asphaltenes were separated from a series of Liaohe biodegraded bitumens and the asphaltenes were analyzed using on-line flash pyrolysis-GC assisted by TMAH thermal hydrolysis and methylation [27]. Results showed that the alkyl moieties bonded to asphaltene macromolecules are dominated by $\mathrm{C}-\mathrm{C}$ and ether (thioether) bonds but less so through ester and hydrogen bonds. Furthermore, the linear alkyl moieties bonded to the asphaltene structure by hydrogen and ester bonds are more susceptible to biodegradation than those bonded to the asphaltene core through stronger covalent bonds such as $\mathrm{C}-\mathrm{C}$ and ether (thioether) bonds. On the other side, the TMAH-thermochemolysis method was also used to study the coal bioconversion activity of nonmycorrhizal fungi in the C. dactylon/coal rhizosphere [197]. The methylation compounds obtained from TMAH thermochemolysis were pyrolysed at $700^{\circ} \mathrm{C}$ for $15 \mathrm{~s}$ and analyzed by GC/MS. Poly(tertbutylstyrene) (0.05 $\mathrm{mg} / \mathrm{mL}$ in hexane) was used as an internal standard and benzeneamine, diazine, dimethylpyranone, furfural, hexadecanoic acid, methylaminophenol, and propanenitrile were semi-quantified. Results showed that low molecular weight organics can facilitate the bioconversion of coal and that the phytobioconversion of hard coal involving plants and microbes which occurs in the rhizosphere promotes the growth of $C$. dactylon.

In summary, TMAH has been mainly used for the characterization of coal or components extracted from coal through Py-GC/MS with or without an extraction method. Most of the studies focused on the qualification of coal composition, while few studies have focused on the quantitative analysis of coal composition. Therefore, the composition of coal or coal-related components needs to be studied in the future. Low molecular weight compounds in coal play an important role in coal pyrolysis $[49,188]$. O-bearing compounds such as $-\mathrm{OH}$, carbonyl group, phenols, alcohols, acids and esters have been detected in the extractions of a brown coal by FTIR characterization. While the abundance of each compound has not been quantified, TMAH thermochemolysis could be used to methylate these organic compounds and quantify the concentrations of the free organic compounds in coal samples.

\subsection{Lacquer and heritage}

Lacquer is a glossy and durable coating material that has been used as an adhesive or painting material for crafts, weapons, wooden products, coffins, and daily necessities, since ancient times all over the world. Some examples of lacquer materials include natural lacquer sap, synthetic lacquer derivatives, and their films. The natural lacquer is made with the sap from lacquer trees, such as the Rhus vernicifera lacquer trees. They are also known as Asian lacquer trees or Shengqi in China and Urushi in Japan, with urushiol being the main lipid component. From the Rhus succedanea trees, which are used as Vietnamese and Chinese Taiwan lacquer, the main lipid component is laccol. Whereas thitsiol is the main lipid compound in the sap from the Melanorrhonea (Gluta) usitata trees; their sap has been used in lacquer from Myanmar, Laos, Cambodia, and Thailand [198]. The Toxicodendron vernicifluum trees grow naturally in Korea and various artifacts coated in the natural lacquer produced from their sap have been excavated there. European lacquers are complex decorative finishes imitating the appearance of Asian lacquer but made from locally available materials and techniques [199].

The sap was used alone or with additives such as flour or clay for the ground layers and they can be colored with pigments or metal fillers. The refined sap was applied on the surface of the relics for protection and/or decoration, and with multiple very thin layers on the top of the artwork. The multiple layers of lacquers can consist of a mixture of oils such as perilla oil, tung oil, tallow tree oil, linseed oil, sesame oil, tee seed oil, and Canola oil or Rapa oil [200]; resinous materials include waxes or synthetic resins; colorants and pigments; proteins such as pig's blood, animal glue, and egg; carbohydrates such as starchy materials (e.g., flour); miscellaneous materials such as the pig gall or bile; and the products of their interaction and degradation. Lacquer is dried under the specific conditions of over $70 \%$ relative humidity (RH) at room temperature overnight, which results in mainly the oxidation and polymerization of main lipid compounds, including the urushiol, laccol, and thitsiol by laccase [201-203]. The unsaturated side-chain autoxidation process occurs after the concentration of lipid monomers decreases to less than $30 \%$. Subsequently, a very sturdy and dense lacquer film is formed and its properties are of extreme hardness (approximately $6 \mathrm{H}$ pencil hardness) and insolubility due to accelerating nucleus-side chains $(\mathrm{C}-\mathrm{C}, \mathrm{C}-\mathrm{O}-\mathrm{C})$ and side chain-side chain (C-C) cross-linkages [204]. These properties make it difficult to analyze the consistency of lacquers, especially the organic compounds that have been used in lacquers.

Lacquer is a glossy and durable coating material that has been used for thousands of years. The investigation of the composition of lacquer, with the aim of further enriching scholarship and contributing to our understanding of history, helps the archaeologist to understand global historical trade practices and heritage of the coating skills. Therefore, several analytical 
instruments have been used to characterize the composition of different lacquers, such as FTIR [205,206], which is commonly applied to the characterization of the organic functional groups in ancient artworks and ancient buildings because it is a nondestructive method. For example, it was shown that the utilization of natural organic compounds such as rice soup, the juice from vegetable leaves, egg whites, tung oil, fish oil, or even animal blood can greatly improve the performance of lime mortars [207]. Infrared spectroscopy in the range of $4000-600 \mathrm{~cm}^{-1}$ (middle IR) is one of the most widely used techniques for the detection of organic materials [207], such as the CO stretching vibrations at around 1228, 1164, and $1087 \mathrm{~cm}^{-1}$, the ester carbonyl stretching band at around $1740 \mathrm{~cm}^{-1}$, NH bending vibrations at around $1584 \mathrm{~cm}^{-1}$, etc. [206]. However, FTIR was found to be unable to differentiate the organic structures of similar lacquers and the various organic and inorganic materials that were mixed with different lacquer saps [208], to differentiate the original lacquer tree of a given lacquer, and to distinguish macromolecular peptides and proteins. The peaks from the solid state nuclear magnetic resonance (NMR) spectroscopy could demonstrate the main carbon structures of the organic compounds; however, this technique cannot give precise information because it is difficult to analyze the peaks and obtain clear results [198]. Therefore, Py-GC/MS is widely used as the best method to characterize the components of the different organics. A macromolecular compound is heated at different temperatures and volatiles are formed. These volatiles are carried by a carrier gas into the GC for separation and the MS for detection. This method requires lower sample amounts and simple manipulation and pre-treatment of the sample. Though Py-GC/MS is an efficient instrument to acquire the fingerprint information of organic matter in lacquers, varnishes, and paintings, there are some refractory materials for which it is difficult to form volatiles with the pyrolysis process and thus it is difficult to detect these molecules directly by GC/MS. Therefore, wet chemistry, mainly derivatization reactions, is combined with Py-GC/MS to elucidate the composition and structure of the target materials at the molecular level. Among various derivatization methods, as described in section 1.2, TMAH-Py-GC/MS has been shown to dramatically improve the sensitivity and specificity of organic analysis, such as in a study of the composition of Chinese lacquers [200,209-214]. These methods have been widely used for the analysis of artwork from many countries, including artwork from China, Korea and Japan, as well as some European countries such as Italy [215], the Netherlands [216], Spain [185] and Portugal [217].

TMAH-Py-GC/MS is a practical method for the characterization of ancient art works, especially the composition of lacquer, such as the black lacquers of 19th-century furniture [218], European lacquer [199], wooden chips [219], varnish [206,220,221], the paints of antiques, historical coatings on objects of art [222] and the organic matters of archaeological scenarios [79,223,224]. Lists of markers generated in this process could be added into a database to improve the interpretation of complex mixtures in lacquers and combined with other complementary techniques for the compositional analysis of coatings, lacquers, pigments and binders in different antique and ancient architecture. For example, Cauzzi [225] studied the chemical compositions of sculptural polychromy of employed materials and pigments of the Buddha in the Zhongshan Grottoes (R.P.C.) using Raman analysis, Fourier-transform infrared analysis, analysis through energy-dispersive X-ray spectrometry coupled to scanning electron microscopy and Py-GC/MS. TMAH was used to analyze the compositions of the pigments with Py-GC/MS [226]. Resinous constituents of varnishes on 19th and early 20th century tintypes were analyzed by TMAH-Py-GC/MS and the resinous materials of the collection tintypes were analyzed. This was the first largescale analysis of tintype manufacturing and provided unique information on the working habits of photographers during the 19th and early 20th centuries. A summary of the applications of TMAH-Py-GC/MS and the main analyzed compositions of ancient art-objects are listed in Table 3.

TMAH-Py-GC/MS can be used to analyze the organic components of different relics, other organic substances, and sap mixtures of urushiol, laccol, and thistsiol with two phenolic hydroxyls. Fatty acids reveal the presence of oils, which can be further identified according to the ratio of certain fatty acids. For example, drying oils can be identified by a ratio of azeleic acid to palmitic acid methyl esters (the so-called A/P ratio); the ratios of palmitic to stearic acid methyl esters ( $\mathrm{P} / \mathrm{S}$ ratios) at 1.0-1.2 show the presence of tung oil.

TMAH thermochemolysis is mainly the methylation of hydroxides of phenolic compounds, alcohols, saturated and unsaturated long-chain fatty acids, etc. [227,228]. Fig. 3 shows the mechanism of TMAH thermochemolysis of different species, in which methylation plays a key role. Indeed, these compounds can be used as biomarkers to determine the origin of the lacquers or the trade among countries. TMAH thermochemolysis methods are not only used to study specific questions surrounding a material's composition, but also for elucidating aging/deterioration mechanisms and restoration treatments for long-term preservation of art-objects. For example, Katsibiri [229] characterized the properties, function and chemical composition of mordants and the deterioration that occurred during aging of the mordants. In this study, the TMAH was used as a methanolic solution for the samples to give complementary information combined with the EI-DTMS method. By comparing the differences and similarities of wall paintings across three churches, a common painter was identified. The compositional evolution of different ancient artworks is its own field of study since the natural aging or man-made decay problems of paintings is one of the most important problems in the hermitage science field.

Some researchers simulated the aging process and studied the effect of environmental conditions on the aging process of selected artworks [35,230,231]. For example, Ploeger [232] characterized the artists' alkyd paints and paint stability issues using characterization methods such as Fourier transform infrared spectroscopy attenuated total reflectance (FTIR-ATR) to analyze different functional groups. Py-GC/MS combined thermal hydrolysis and methylation methods to disclose the monomers used to manufacture an alkyd resin. Results showed that the aged films were brittle and difficult to handle, because of the high molecular weight of the alkyd polymer and faster stiffening from the excessive cross-linking and subsequent degradation reactions. The conclusion was that they should be preserved in conditions similar to those used for oil paintings.

The amount of recorded literature on the application of TMAH thermochemolysis in archeology over the last 10 years is about 5 times higher than that during the ten-year period before 2010. A wide range of organic compounds were detected, including natural resins and fatty acids, which demonstrated that the TMAH-Py-GC/ MS is an efficient method to analyze the organic compounds in coatings or paint layers of ancient artworks. This method could determine the compositions and the origin of lacquers, varnishes, and paints of relics, which played a key role in the conservation and restoration of ancient artworks. In addition, some advanced characterization technologies were used to characterize ancient artworks comprehensively, such as light microscopy (LM), optical microscopy (OM), direct temperature resolved mass spectrometry (DTMS), scanning electron microscopy-energy dispersive X-ray 
Table 3

The organic compounds detected in ancient samples with TMAH-Py-GC/MS in previous studies.

\begin{tabular}{|c|c|c|c|c|c|c|}
\hline Sample & Compounds & TMAH volume & $\begin{array}{l}\text { Derivatization } \\
\text { method }\end{array}$ & $\mathrm{T}_{\text {pyrolysis }}$ & Year & Publication \\
\hline Bronze vessels & $\begin{array}{l}\text { Glycero lipids of animals or } \\
\text { animal + plant origin; PAHs }\end{array}$ & $5 \mu \mathrm{l}, 25 \% \mathrm{w} / \mathrm{w}$ in water & On-line & $\begin{array}{l}600^{\circ} \mathrm{C} \\
10 \mathrm{~s}\end{array}$ & 2011 & [342] \\
\hline Orange glaze & $\begin{array}{l}p \text {-coumaric acid, linseed oil, colophony } \\
\text { and sandarac }\end{array}$ & $2-3.5 \mu \mathrm{l}, 25 \%$ in methanol & On-line & $550^{\circ} \mathrm{C}$ & 2011 & [343] \\
\hline Harpsichord & $\begin{array}{l}\text { Cupressaceae or Araucariaceae resins, } \\
\text { Pinaceae resin }\end{array}$ & $0.5 \mu \mathrm{l}, 25 \%$ in methanol & On-line & $610^{\circ} \mathrm{C}, 10 \mathrm{~s}$ & 2012 & [344] \\
\hline Crucifix panel & $\begin{array}{l}\text { Hexadecanoic acid; nonanedioic acid; } \\
\text { the methyl ester of 7-oxo- } \\
\text { dehydroabietic (7-oxo-DHA) acid; } \\
\text { poly(n-butylmethacrylate) and } \\
\text { diterpenoid Pinaceae resin; acrylic } \\
\text { copolymer poly(ethylmethacrylate- } \\
\text { methylacrylate) }\end{array}$ & $3 \mu \mathrm{l}, 25 \%$ in water & On-line & $600^{\circ} \mathrm{C}$ & 2013 & [310] \\
\hline Sculptural polychromy & Saccharidic derivative; Fatty acids & $5 \mu \mathrm{l}$, at $25 \% \mathrm{w} / \mathrm{w}$ in water & On-line & $750^{\circ} \mathrm{C}, 10 \mathrm{~s}$ & 2013 & [225] \\
\hline Cartonnage masks & $\begin{array}{l}\text { Permethylated and partially } \\
\text { methylated 3-deoxyaldonic acids }\end{array}$ & $5 \mu \mathrm{l}, 25 \%$ in water & Off-line (30min) & $300^{\circ} \mathrm{C}-700^{\circ} \mathrm{C}$ & 2014 & [345] \\
\hline Tintypes & $\begin{array}{l}\text { Camphor, dammar, Pinaceae, sandarac, } \\
\text { and shellac }\end{array}$ & $3 \mu \mathrm{l}, 25 \%$ in methanol & Off-line (3min) & $550^{\circ} \mathrm{C}, 6 \mathrm{~s}$ & 2014 & [226] \\
\hline Wooden screen & $\begin{array}{l}\text { Pine resin (colophony) and shellac, } \\
\text { urushiol and different oils; blood (most } \\
\text { likely pigs' blood). }\end{array}$ & $3 \mu \mathrm{l}, 25 \%$ in water & Off-line (3min) & $550^{\circ} \mathrm{C}, 6 \mathrm{~s}$ & 2016 & {$[346]$} \\
\hline Rectangular trays & $\begin{array}{l}\text { Laccol (arlenic acid, C17), and drying } \\
\text { oils, such as perilla oil, protein, soot; } \\
\text { blood, pine resin, beeswax. }\end{array}$ & $3 \mu \mathrm{l}, 25 \%$ in methanol & Off-line (3min) & $550^{\circ} \mathrm{C}, 6 \mathrm{~s}$ & 2016 & [347] \\
\hline Gloss paints & $\begin{array}{l}\text { Drying oil; such as palmitic, stearic, } \\
\text { azelaic acid, suberic, sebacic acid, } \\
\text { dehydroabietic acid, 7-oxo- } \\
\text { dehydroabietic acid, 15-hy- droxy-7- } \\
\text { oxo-DHA. }\end{array}$ & $2 \mu \mathrm{l}, 25 \%$ in methanol & On-line & $550^{\circ} \mathrm{C}$ & 2016 & [348] \\
\hline European scale armor & $\begin{array}{l}\text { Wax and lipids, with fatty acids possibly } \\
\text { from multiple sources (oils, fat, wax, } \\
\text { soil) }\end{array}$ & $3 \mu \mathrm{l}, 25 \%$ in methanol & On-line & $550^{\circ} \mathrm{C}$ & 2017 & [349] \\
\hline Wall paintings at Caere & $\begin{array}{l}\text { No organic binding medium was } \\
\text { detected. }\end{array}$ & $1.6 \mu \mathrm{l}, 25 \%$ in methanol & On-line & $50^{\circ} \mathrm{C}-450^{\circ} \mathrm{C}(3 \mathrm{~min})$ & 2017 & [350] \\
\hline Part of wall paintings & $\begin{array}{l}\text { Fatty acid (especially high content of } \\
\text { azelaic acid); rosin resin; protein; the } \\
\text { binding medium includes animal glue; } \\
\text { bovine (or yak) glue; Tung oil and rosin } \\
\text { resin }\end{array}$ & $3 \mu \mathrm{l}, 25 \%$ & Off-line (60 min) & $600^{\circ} \mathrm{C}, 10 \mathrm{~s}$ & 2018 & [351] \\
\hline Tie luo & Animal glue, drying oils, beeswax & $5 \mu \mathrm{l}$ of $10 \%$ methanol & On-line & $600^{\circ} \mathrm{C}, 0.2 \mathrm{~min}$ & 2018 & [352] \\
\hline $\begin{array}{l}\text { Folding doors in foyer at } \\
\text { Herlev Hospital }\end{array}$ & $\begin{array}{l}\text { Phthalic acids, monocarboxylic acids } \\
\text { caproic (C6:0), capric (C10:0), palmitic } \\
\text { (C16:0), oleic (C18:1), stearic (C18:0), } \\
\text { dicarboxylic acids suberic (2C8), azelaic } \\
\text { (2C9), dehydroabietic acid (DHA), 7-oxo } \\
\text { DHA, 7-methoxy-tetradehydroabietic } \\
\text { acid. }\end{array}$ & $15 \mu \mathrm{l}, 2.5 \%$ in methanol & On-line & $550^{\circ} \mathrm{C}$ for $12 \mathrm{~s}$ & 2018 & [353] \\
\hline $\begin{array}{l}\text { Wooden panel of the } \\
\text { Nongso offin }\end{array}$ & $\begin{array}{l}\text { Markers of drying oil like azelaic acid } \\
\text { and palmitic acid existed in large } \\
\text { quantities. }\end{array}$ & $3 \mu \mathrm{l}, 25 \%$ in methanol & On-line & $550^{\circ} \mathrm{C}$ & 2018 & [354] \\
\hline Furniture in black lacquer & Copal oil and Pinaceae resin & $\begin{array}{l}4 \mu \mathrm{l}, 2.5 \% \mathrm{TMAH} \text { in } \\
\text { methanol }\end{array}$ & - & $480^{\circ} \mathrm{C}$ & 2019 & [218] \\
\hline Hillebrand Desk & $\begin{array}{l}\text { Oils, pine resin, larch turpentine, } \\
\text { sandarac, shellac, gum benzoin. }\end{array}$ & $\begin{array}{l}5 \mu \mathrm{l}, 25 \% \mathrm{TMAH} \text { in } \\
\text { methanol, diluted to } 5 \% \\
\text { with methanol }\end{array}$ & On-line & $\begin{array}{l}360^{\circ} \mathrm{C}-660^{\circ} \mathrm{C} \text { at } \\
500^{\circ} \mathrm{C} \mathrm{min}^{-1}\end{array}$ & 2019 & [199] \\
\hline Four resins & Resins & $\begin{array}{l}2 \mu \mathrm{L} 2.5 \mathrm{wt} \% \text { in methanol } \\
\text { from } 25 \mathrm{wt} \% \text { in methanol }\end{array}$ & On-line & $480^{\circ} \mathrm{C}$ & 2019 & [222] \\
\hline “Tixi” carved lacquer & $\begin{array}{l}\text { Pigment (soot, black layer), orpiment } \\
\text { (yellow layer), cinnabar (red layer), } \\
\text { lacquer sap, heat-bodied tung oil and } \\
\text { tannins (partial layer); catechols, acid } \\
\text { catechols, phenols, alkyl benzenes, and } \\
\text { hydrocarbons of a maximum side chain } \\
\text { length of } 17 \text { carbons; alcohols. }\end{array}$ & $2 \mu \mathrm{l}, 25 \mathrm{wt} \%$ in methanol & On-line & $550^{\circ} \mathrm{C}, 6 \mathrm{~s}$ & 2019 & [210] \\
\hline Cabinet on stand & Shellac, pine resin & $5 \%$ & - & $350^{\circ} \mathrm{C}-700^{\circ} \mathrm{C}$ & 2019 & [216] \\
\hline Bartolomeu Dias table & $\begin{array}{l}\text { The binder is a mixture of proteins } \\
\text { (primarily animal glue and blood) and } \\
\text { drying oil; laccol was detected for the } \\
\text { bottom lacquer layer and a mixture of } \\
\text { laccol and urushi for the top lacquer } \\
\text { layers }\end{array}$ & $3 \mu \mathrm{l}, 25 \%$ in methanol & Off-line (1 min) & $600^{\circ} \mathrm{C}, 12 \mathrm{~s}$ & 2019 & [205] \\
\hline Lamp panel, fuel residue & $\begin{array}{l}\text { Long-chain fatty acids, fatty alcohols } \\
\text { and hydrocarbons, beeswax }\end{array}$ & $3 \mu \mathrm{l}$ of $25 \%$ in water & On-line & $550^{\circ} \mathrm{C}$ & 2019 & [355] \\
\hline
\end{tabular}




$$
\text { Alcohol: } \quad \mathrm{R}-\mathrm{OH} \quad \underset{\Delta}{\stackrel{\mathrm{TMAH}}{\longrightarrow}} \mathrm{R}-\mathrm{O}-\mathrm{CH}_{3}
$$

Carboxylic acids:

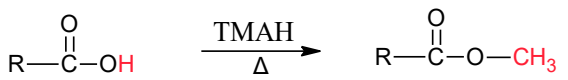

Phenolics:<smiles>[R]c1cccc(O)c1O</smiles><smiles>[R]c1ccc(O)c(O)c1</smiles><smiles>[R]c1ccc(OC)c(OC)c1</smiles><smiles>[R]c1cc(O)cc(O)c1</smiles><smiles>[R]c1cc(OC)cc(OC)c1</smiles><smiles>[R]c1cccc(O)c1</smiles><smiles>C[Mg][Mg]</smiles><smiles>[R]c1cccc(OC)c1</smiles><smiles>[R]c1ccc(O)cc1</smiles>
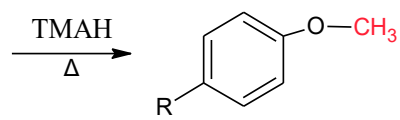

Fig. 3. TMAH thermochemolysis with different organic compounds.

spectroscopy (SEM-EDX), etc. However, few studies have focused on the quantitation of lacquer.

\subsection{Soil}

The importance of organic matter within soil cannot be overemphasized because this organic matter plays a vital role for life, as a nutrient source, an energy and cation reservoir or source, a $\mathrm{pH}$, temperature, and water storage buffer, an absorber of toxic organic compounds and inorganic ions, an enzyme activity controller, and finally, a major role player in greenhouse gas regulation [233]. The organic matter in soil is primarily responsible for the soil properties that control the productive capacity of soil and the sustainability of a productive soil system [234]. Therefore, it is of great importance to gain as much insight as possible into organic compounds within soils on the Earth. TMAH-Py-GC/MS is one of the most used methods for the characterization of organic compounds within soil samples. This method has been widely used in the analysis of forest soil [235], farmland [97], cattle husbandry soil [236], coastal Wetland soils [78], permafrost sediments [237], archaeological settings [79], peat soil [36,96,238], forensic soil [239], archaeological scenarios [79], and river sediments [24,240-243]. The organic compounds that have been detected in different soil samples are summarized and listed in Table 4.

The organic matter in soil can be classified into four categories: i) particulate organic matter, ii) humus, iii) resistant soil organic matter and iv) dissolved organic compounds [234,244]. The particulate organic matter, or particulate organic carbon (POC), is composed of decomposing plant residues, fungal hyphae, fine plant roots and associated biomasses, which are unstable and have a short turnover time less than 1-2 years. Lignin and its derivatives are the main decomposition products of plants and their organs. TMAH thermochemolysis has been widely used to characterize the decomposition products of plants and their organs in forest soil, farmland and Wetland soil. Lignin is also considered to be a major component of soil organic matter (SOM) [245], which mainly comes from the organs of plants such as leaves, roots, and grass litters $[73,93,95]$. The main structure of lignin and its derivatized compounds can be seen in Fig. 1 in section 2.1 lignin and plants.

The humus part of the soil has a longer turnover time, around 2-25 years, and includes partially stabilized organic materials and microbial metabolites. The resistant soil organic matter is strongly stable either chemically or physically and may be part of the humus fraction. Its turnover time is about 250-2500 years [234,244]. The humic substances represent approximately $40-60 \%$ of the soil organic matter, including humin, humic acid, and fulvic acid. Humin (C-based macromolecular compounds) is the insoluble fraction of humic substances. Humic acids are soluble under alkaline conditions and fulvic acid is the fraction that is soluble under both alkaline and acidic conditions. Humic substances can influence the soil buffering capacity, increase moisture retention, and supply plants with available micronutrients. These compounds can also interact with complex metals which alleviates both heavy metal toxicity and metal deficiency in soils [246]. Therefore, it's important to characterize the structure of humic substances in soil. Branched-chain fatty acids and methyl esters are related to a large amount of humic acid structures in the soil, and can be used as biomarkers in humic substances from matured compost samples. A higher level of branched-chain fatty acids indicates a higher aromaticity and lower molecular weight of humic substances and provides information on the history of microbial activities during the composting process [102]. The structures of humic substances are related to the soil function [24]. For example, humic substances from sugar cane cultivation areas were found to contain compounds rich in lipids and fatty acids [24,105]. The salinity of the soil can also affect the compositional formation of humic acids, with one study suggesting an increasing recalcitrance of humic acids along the salinity gradient. The same study observed a higher percentage of aromatics in humic acid compounds in soil with higher clay content [78]. Steel slag-compost fertilizer was shown to alter the steel slag during the fertilization period, mainly involving a decrease in phenolic moieties and a significant increase in the sulfur-containing pyrolysate compounds [84].

The dissolved organic compounds, mainly including sugars, amino acids, soluble P-containing compounds, and low molecular organic acids, make up a small but essential proportion of the soil organic compounds and serve a wide range of functions, most notably nutrient cycling [24]. Polysaccharides were used as an indicator and proxies have been proposed for the reconstruction of past peatland vegetation [247]. TMAH thermochemolysis has been proven to be able to analyze amino acids which consequently represent one of the most important components in the organic $\mathrm{N}$ cycle [64]. On the other side, microbial communities also play an important role for soil and drive the transformation of organic components in soil [172,236], TMAH thermochemolysis was used for the characterization of changes in soil microbial communities 
Table 4

The organic compounds detected in soil samples with TMAH-Py-GC/MS in previous studies.

\begin{tabular}{|c|c|c|c|c|c|c|}
\hline Soil location & Organic compounds & TMAH volume & $\begin{array}{l}\text { Derivatization } \\
\text { mode }\end{array}$ & $\mathrm{T}_{\text {Pyrolysis }}$ & Year & Publications \\
\hline Mediterranean forest soil & $\begin{array}{l}\text { Fatty acids, } n \text {-alkanols, } \alpha, w \text {-diacids, } \\
\text { hydroxyacids, ligneous subunits, } \\
\text { carbohydrates }\end{array}$ & $\begin{array}{l}2 \mathrm{~mL} 50 \%(\mathrm{w} / \mathrm{w}) \text { in } \\
\text { methanol }\end{array}$ & Off-line & $400^{\circ} \mathrm{C}$ & 2009 & [88] \\
\hline Weerterbergen in The Netherlands. & $\begin{array}{l}\text { Lignin, polysaccharides, phenols } \\
\text { diketodipyrrole, } n \text {-alkenes/n-alkanes } \\
\text { (C10-C33), } 2 \text {-methylketone; alkanoic } \\
\text { acid }\end{array}$ & A droplet, $25 \%$ in water & - & $600^{\circ} \mathrm{C}, 5 \mathrm{~s}$ & 2010 & [70] \\
\hline $\begin{array}{l}\text { Acer pseudoplatanus on Petrín hill in } \\
\text { Prague in May } 2010 .\end{array}$ & litters & Excess, $25 \%$ in water & Off-line & $550^{\circ} \mathrm{C}, 10 \mathrm{~s}$ & $\begin{array}{l}2011 \\
2014\end{array}$ & {$[92,93]$} \\
\hline Loire and the Gartempe rivers & $\begin{array}{l}\text { Heterocyclic compounds, } N \text {-containing } \\
\text { compounds }\end{array}$ & $25 \%(w / v)$ in methanol & - & $650^{\circ} \mathrm{C}, 10 \mathrm{~s}$ & 2012 & [72] \\
\hline Coastal Wetland soils & $\begin{array}{l}\text { Aliphatic compounds, lignin-derived } \\
\text { compounds, } N \text {-containing compounds, } \\
\text { Polysaccharide-derived compounds, S- } \\
\text { containing compounds }\end{array}$ & - & & $620^{\circ} \mathrm{C}, 20 \mathrm{~s}$ & 2012 & [78] \\
\hline $\begin{array}{l}\text { A wet tropical forest on the island of } \\
\text { Hawaii in the Kohala Mountains. }\end{array}$ & $\begin{array}{l}\text { Aromatic, lipid, polysaccharide, } N- \\
\text { bearing, lignin, phenol }\end{array}$ & $5 \mu \mathrm{L}$ & Off-line (24 h) & $590^{\circ} \mathrm{C}$ & 2012 & [71] \\
\hline Koroglu Mountain in Turkey & Amber extract, fossil resin & - & On-line & $480^{\circ} \mathrm{C}, 20 \mathrm{~s}$ & 2014 & [356] \\
\hline $\begin{array}{l}\text { Kervidy-Naizin catchment, in central } \\
\text { Brittany, western France }\end{array}$ & $\begin{array}{l}\text { Lignin and tannin markers, } \\
\text { carbohydrates, and fatty acids. }\end{array}$ & Excess, solid TMAH & On-line & $400^{\circ} \mathrm{C}, 1 \mathrm{~min}$ & 2014 & [82] \\
\hline $\begin{array}{l}\text { Mega Rice Project area in Kalampangan } \\
\text { village and Sebangau National Park } \\
\text { in Central Kalimantan Province, } \\
\text { Indonesia. Mega }\end{array}$ & Humic acids & $25 \mu \mathrm{l}$ & Off-line & $550^{\circ} \mathrm{C}, 4 \mathrm{~min}$ & 2015 & [238] \\
\hline $\begin{array}{l}\text { Soil cores from Shark to Taylor Sloughs, } \\
\text { the primary flowpaths of the } \\
\text { southern Everglades }\end{array}$ & $\begin{array}{l}\text { Kaurenes, cyclic diterpenoids; branched } \\
\text { isoprenoids (C20HBIs) and Bot- } \\
\text { ryococcenes; lignin phenols. }\end{array}$ & $100 \mathrm{mg}$ of reagent & Off-line & - & 2015 & [357] \\
\hline $\begin{array}{l}\text { Soil from the permanent grassland in } \\
\text { the south of France }\end{array}$ & $\begin{array}{l}\text { Leaves and roots (aliphatic compounds, } \\
\text { aromatics) }\end{array}$ & $\begin{array}{l}\text { A few drops, at } 25 \% \text { ) in } \\
\text { methanol }\end{array}$ & On-line & $650^{\circ} \mathrm{C}, 10 \mathrm{~s}$ & 2016 & [73] \\
\hline $\begin{array}{l}\text { Four forest sites situated in the Italian } \\
\text { Alps }\end{array}$ & $\begin{array}{l}\text { Aromatic compounds, polysaccharides, } \\
\text { fatty acids, } N \text {-containing compounds. }\end{array}$ & Excess & On-line & $550^{\circ} \mathrm{C}, 10 \mathrm{~s}$ & 2017 & [94] \\
\hline $\begin{array}{l}\text { Sokolov brown-coal mining district, } \\
\text { Czech Republic. }\end{array}$ & $\begin{array}{l}\text { Litter (aliphatic and aromatic } \\
\text { compounds and a decrease of } \\
\text { carbohydrates) }\end{array}$ & Excess, in water & Off-line & $550^{\circ} \mathrm{C}, 10 \mathrm{~s}$ & 2017 & [95] \\
\hline $\begin{array}{l}\text { Abbaretz }\left(\mathrm{BABZ}^{\wedge}\right), \text { Mioche }\left(\mathrm{BMCH}^{\wedge}\right) \text { and } \\
\text { La Petite Faye }\left(\mathrm{BLPF}^{\wedge}\right) \text {, France }\end{array}$ & $\begin{array}{l}\text { Products originated from proteins, } \\
\text { carbohydrate, lignite, fatty acids, sterols } \\
\text { and lipids fractions. }\end{array}$ & $15 \mu \mathrm{l}$ & On-line & $400^{\circ} \mathrm{C}$ & 2017 & [99] \\
\hline Wetland soil, in Brittany (France). & $\begin{array}{l}\text { Lignin and tannin markers, } \\
\text { carbohydrates and fatty acids. }\end{array}$ & Excess, solid TMAH & On-line & $400^{\circ} \mathrm{C}, 1 \mathrm{~min}$ & 2018 & [83] \\
\hline $\begin{array}{l}\text { Chateau de Versailles in Versailles; } \\
\text { Rothamsted Research, United } \\
\text { Kingdom; the Swedish University of } \\
\text { Agricultural Sciences, Sweden; Askov } \\
\text { Experimental Station, Denmark }\end{array}$ & $\begin{array}{l}\text { Aromatic compounds, lignin-derived } \\
\text { compounds and phenolic compounds, } \\
\text { aliphatic compounds, carbohydrates } \\
\text { and } N \text {-containing compounds }\end{array}$ & $\begin{array}{l}\text { A few drops, } 25 \%(w / w) \text { in } \\
\text { methanol }\end{array}$ & On-line & $650^{\circ} \mathrm{C}, 10 \mathrm{~s}$ & 2018 & [74] \\
\hline $\begin{array}{l}\text { Araguás catchment (Central Spanish } \\
\text { Pyrenees) }\end{array}$ & Lignin $(0-0.74 \mu \mathrm{g} \mathrm{mg}$ in soil $)$ & $20 \mu \mathrm{L}, 25 \%(\mathrm{w} / \mathrm{w})$ in water & Off-line(2 min) & $600^{\circ} \mathrm{C}, 5 \mathrm{~s}$ & 2019 & [75] \\
\hline $\begin{array}{l}\text { Archaeological Sites, the NW of the } \\
\text { Iberian Peninsula }\end{array}$ & $\begin{array}{l}\text { Monocyclic aromatic hydrocarbons, } \\
\text { methylene chain compounds; } N \text { - } \\
\text { compounds; short-chain FAMEs } \\
(\mathrm{C} 16, \mathrm{C} 18) \text {; lignin }\end{array}$ & $25 \%$ in water & - & $750^{\circ} \mathrm{C}, 20 \mathrm{~s}$ & 2019 & [79] \\
\hline
\end{tabular}

by analyzing the changes in the inner composition of soil organics such as ligninocellulose or lignin [74,236].

Overall, TMAH thermochemolysis combined with Py-GC/MS or GC/MS has been used to analyze various organic compounds such as humic acids, fatty acids, lignin, $\mathrm{N}$-containing compounds, and aliphatic and aromatic compounds in soil samples GC/MS.

\subsection{Polymers}

To expand the applications of Py-GC/MS and THM, induced by the most widely applied thermochemolysis reagent, TMAH, we will cover the wide usage of this method for the structural characterization of various polymer samples [18,248-251]. During the pyrolysis and THM method, specific chemical bonds including ester, ether, and carbonate linkages of different polymers can be decomposed forming smaller methylated fragments which are amenable to GC/MS analysis. However, the products of polymers without ether, ester, and carboxylic bonds (polar compounds) are unaffected by TMAH thermochemolysis, such as polyethylene (PE), polypropylene (PP), polystyrene (PS), and polyvinyl chloride (PVC). However, TMAH thermochemolysis shows a good performance on the analysis of polyethylene terephthalate (PET), polycarbonate (PC), poly(methyl methacrylate) (PMMA), poly(alkyl methacrylate), polyamide 6 (PA6), and nylon. For those compounds the thermochemolytic transmethylation is the main mechanism of the TMAH reaction [76,251]. Though TMAH thermochemolysis did not show good performance on the analysis of polyethene, it can be used to predict the lifetime of artificial aging problems. By aging the unstablized polyethylene in water at elevated temperature and under a high pressure of oxygen, the TMAH thermochemolysis method can be applied to assess the degree of oxidation. In this study, $\alpha, w$-diacids are the valuable indicators to determine the degree of oxidation of PE aging, which is caused by the attraction of hydroxyl to the carbonyl group and cleavage of the $\mathrm{C}-\mathrm{C}$ backbone to yield carboxylic acids [252]. 
Poly (butylene succinate-co-butylene adipate) (PBSA) is one of the popular commercial packaging and container materials that can be biodegraded, because its physical properties are similar to those of commodity plastics with a good biodegradability. TMAH thermochemolysis was applied to characterize its structure and the degradation byproducts of it. Baidurah $[253,254]$ evaluated the biodegradability of PBSA based on its copolymer composition using THM-GC method. The butylene succinate (BS) and the butylene adipate (BA) units are the original components of PBSA. The copolymer composition of butylene adipate (BA) units decreases with soil burial degradation time. Butanediol dimethyl ether (BD), butanediol monomethyl ether (BM), dimethyl succinate (SD), and dimethyl adipate (AD) were the characteristic peaks of PBSA degradation in the presence of TMAH, and they were used to calculate the content of BS and BA units in PBSA. Later, they clarified the cause of the changes of BS and BA units in copolymer composition, and studied the biodegradation behavior of PBSA with lowered crystallinity using the TMAH-GC method. Results showed that the butylene adipate (BA)-rich moieties in the copolymer chains could show relatively lower crystallinity than the butylene succinate (BS)-rich moieties and that they were preferentially biodegraded during soil burial tests, leading to the decrease in the BA content as the biodegradation proceeded.

Poly (3-hydroxybutyrate-co-3-hydroxyhexanoate) [P(3HB-co$3 \mathrm{HHx})]$ is one of the biodegradable co-polyesters, which can be produced by several types of bacteria such as Cupriavidus necator and Aeromonas caviae and serve as their energy storage compounds. In order to control the biodegradability of the [P(3HB-co$3 \mathrm{HHx})]$, it is of importance to analyze the structure of [P(3HB-co$3 \mathrm{HHx})]$. Baidurah $[255,256]$ studied the composition of [P(3HBco-3HHx)] accumulated in whole bacterial cells using TMAH THM-GC method. Characteristic compounds of $3 \mathrm{HB}$ and $3 \mathrm{HHx}$ units were determined. Methyl 3-butenoate, methyl cis-2butenoate, methyl trans-2-butenoate, and methyl 3methoxybutanoate originated from 3HB. Methyl cis-2hexenoate, methyl trans-3-hexenoate, methyl cis-3-hexenoate, methyl trans-2-hexenoate, and methyl 3-methoxyhexanoate are products of $3 \mathrm{HHx}$. They also studied the soil burial biodegradation of [P(3HB-co-3HHx $)$. The chemical composition of 3HB units increased while $3 \mathrm{HHx}$ units decreased with the soil burial time. In addition, THM-GC was also applied to direct analysis of poly(3hydroxybutyrate-co-3-hydroxyvalerate) $[\mathrm{P}(3 \mathrm{HB}-\mathrm{co}-3 \mathrm{HV})]$ in Cupriavidus necator cells, without any appreciable pretreatment of the bacterial matrix [32]. Through analyzing the yield of the characteristic peaks $3 \mathrm{HB}$ and $3 \mathrm{HV}$, results from THM-GC in the presence of TMAH were demonstrated in good agreement with those obtained from conventional technique, which is in alignment with the result obtained from study of polyhydroxybutyrate (PHB) film with TMAH-GC without any cumbersome sample pretreatment [33].

Tetramethylammonium acetate (TMAAc) was also used to analyze styrene/butyl acrylate/methacrylic acid terpolymer by a two-step reactive Py-GC process [18]. TMAAc was applied to control the undesirable transesterification. A solid ammonium $\mathrm{Y}$ zeolite was used as a thermochemolysis reagent for identification of polyethers and polyesters [249]. TMAH is the main thermochemolysis reagent used in the characterizations of various polymers. The main structure of polymers can be seen in Fig. 4. Aldehyde, carboxyl, ether, and ester functional groups are the main structures that react with TMAH and on which the methylation occurs.

\subsection{Thermochemolysis for space exploration}

TMAH is used in space experimentation devoted to in situ characterization of the chemical composition of martian soils with automatized analytical laboratories. The SAM (Sample Analysis at Mars) experiment onboard the Curiosity rover of the Mars Science Laboratory mission, and MOMA (Mars Organic Molecule Analyzer), onboard the Rosalind Franklin rover of the Exomars mission, are able to implement TMAH thermochemolysis through an experimental set-up developed to meet the technical requirements for use on Mars. TMAH thermochemolysis will also be implemented in the future DraMS instrument onboard the Dragonfly drone that will explore the surface of Titan starting from 2034. However, only rare studies have been focused on the application of thermochemolysis in space. David [257] tested a pilot laboratory model for validation of the on-line preatreatment for analyses of organics by GC/MS, including the derivatization solvents MTBSTFA as a silylating reagent, and $\mathrm{N}, \mathrm{N}$-dimethylformamide dimethylacetal (DMF-DMA) and TMAH as methylating agents.

\subsubsection{Thermochemolysis in the Sample Analysis at Mars (SAM) experiment}

SAM is a complete in situ chemistry laboratory which is part of the Mars Science Laboratory mission and operates onboard the Curiosity rover. SAM includes a Gas Chromatograph (GC) and a Quadrupole Mass Spectrometer (QMS) which are coupled together to detect the organic molecules potentially present in the solid samples collected by the rover [258]. With this aim, a sample preparation and gas processing system is used to vaporize the molecules, and it includes three different techniques adapted to different organic molecules of interest: (i) a pyrolysis system heating the sample up to $\sim 850^{\circ} \mathrm{C}$, (ii) derivatization using silylation process with MTBSTFA/DMF (400 $\mu \mathrm{L} / 100 \mu \mathrm{L})$, (iii) TMAH (25\% in methanol) thermochemolysis.

Derivatization and thermochemolysis have been developed and adapted for in-situ space applications by several authors [259-261]. For SAM, $500 \mu \mathrm{l}$ of each derivatization reagent (MTBSTFA/DMF and TMAH) is placed in the bottom of nine ( 7 for MTBSTFA/DMF and 2 for TMAH) of the 74 metal ovens. The bottom (outer volume) of each cup which contains the derivatization reagent is closed with an aluminum foil which is punctured when the sample is delivered into the oven [38]. The inner volume of the cup contains a standard compound (nonanoic acid for TMAH and 3fluoro-DL-valine for MTBSTFA). This internal standard is reactive with the reagent and it is used as a control compound to check the reaction worked well (Fig. 5).

Up today, only pyrolysis and wet chemistry based on MTBSTFA/DMF have been used to extract and analyze organic molecules present in the martian samples collected. The instrument allowed to detect chlorinated (chlorobenzene, dichlorobenzene, etc.) and sulfur-bearing compounds [262-264] (thiophene and thiophene derivatives) proving for the time that organic matter is present at the Mars surface despite the harsh environmental conditions. Chlorinated compounds are most certainly the result of a reaction of martian perchlorate with endogenous martian organic compounds [265]. Because sulfurbearing compounds have been detected at high temperature, two hypotheses have been proposed to explain their origin: i) they are refractory compounds endogenous to the martian sample, and ii) they are compounds released after reaction with sulfur-bearing compounds.

The strengths of TMAH thermochemolysis on SAM include desorption of organic compounds from the soil, a decrease in the polarity of the released products (through the methylation reaction) and a limitation of secondary reactions, resulting in improved chromatographic performance. Moreover, it is then easier to determine the analyte's parent molecular structure. Several authors showed that under SAM conditions TMAH thermochemolysis enabled the analysis of carboxylic acids (fatty 


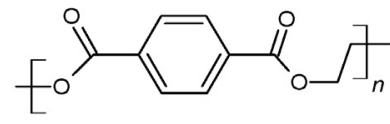

PET[Polyethylene terephthalate]<smiles>CC(C)(C)Oc1ccc(C(C)(C)c2ccc(OC(=O)C3(C)CC3)cc2)cc1</smiles>

PC[Polycarbonate]<smiles>COC(=O)C(C)(CC(C)(C)C)C(=O)OC</smiles>

PMMA[Poly(methyl methacrylate)]<smiles>CC(C)(C)NC(C)(C)CC(C)(C)C(=O)C(C)(C)C</smiles>

PA6[Polyamide 6]<smiles>CN(CC(C)(C)NC(C)(C)C)C(=O)C(C)(C)CC(=O)NC(C)(C)C</smiles>

PA66[Polyamide 66]<smiles>CC(CC1CCC1)C1CCC1</smiles>

PHB[Polyhydroxybutyrate]<smiles>CCCC(CC(=O)C(C)(C)C)O[PH](C)(C)C(=O)CC(C)OC(C)(C)C</smiles>

$\mathrm{P}(3 \mathrm{HB}-c o-3 \mathrm{HHx})$ [Poly(3-hydroxybutyrate-co-3-hydroxyhexanoate)]

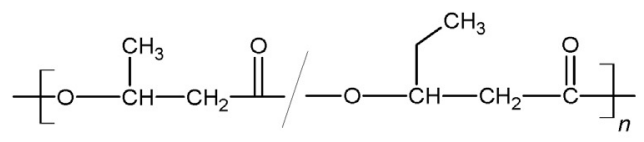

$\mathrm{P}(3 \mathrm{HB}-c o-3 \mathrm{HV})[\mathrm{Poly}(3-$ hydroxybutyrate-co-3-hydroxyvalerate) $]$

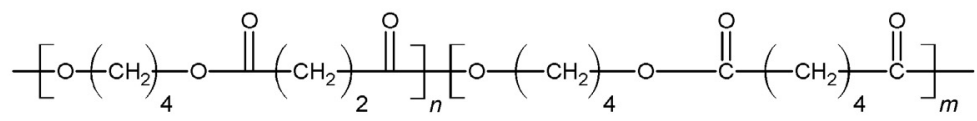

PBSA[Poly(butylene succinate-co-butylene adipate]

Fig. 4. The structures of polymers that react with TMAH during thermochemolysis, adapted from Ref. [18,32,33,248-256].

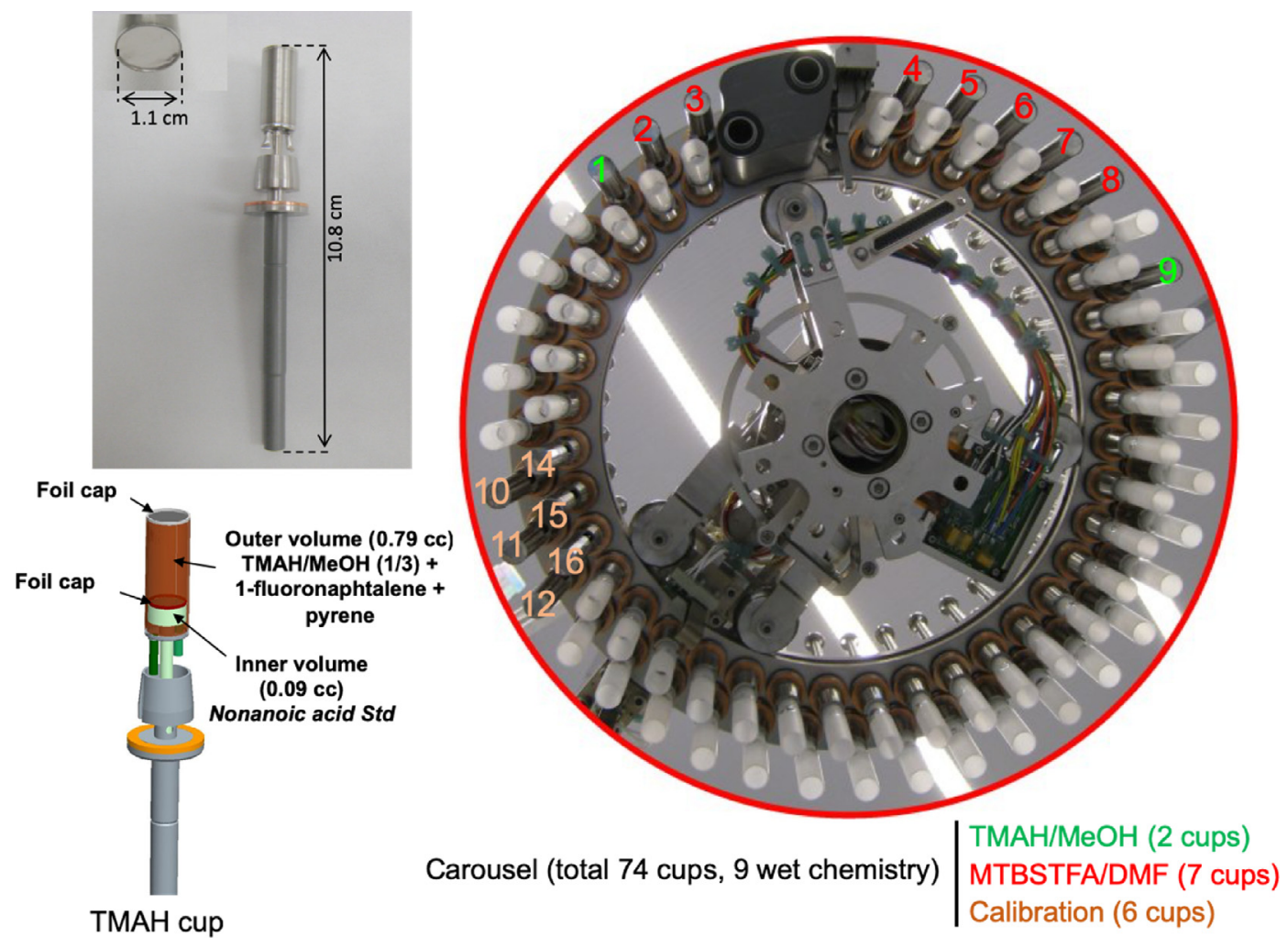

Fig. 5. Sample Monitoring System (SMS) and close up of the SAM oven. Adapted from [268].

acids), amino acids, and nucleobases [31,266,267] from standard samples but also from natural and analog samples [268]. Indeed, authors showed that under SAM-like pyrolysis conditions [268] TMAH thermochemolysis allows the extraction and analysis of fatty acid methyl esters (FAMEs) from martian analog samples.

Because one (or more) of the SAM cups containing MTBSTFA/ DMF leaks, it is possible that TMAH may be put in contact with 
MTBSTFA/DMF when it will be used for the first time. Williams [268] studied the recovery of fatty acids from mineralogical Mars analogs by TMAH-Py-GC/MS. The experimental parameters were analyzed, including the sample exposure time to TMAH, possible TMAH reactions with MTBSTFA, and loss of the TMAH solvent methanol prior to sample pyrolysis. Results showed that the MTBSTFA vapor could react with TMAH in some ways that the evaporation of methanol will not have a significant effect on the TMAH thermochemolysis, and that TMAH shows a good performance on the methylation of FAMEs. However, iron sulfide presents a challenge for thermochemolysis. Further studies need to be conducted in the future such as the recovery of TMAH thermochemolysis on other organics, such as carbolic acids and complex organics such as DNA or RNA.

\subsubsection{Thermochemolysis in the Mars Organic Molecule Analyzer (MOMA)}

The Mars Organic Molecule Analyzer (MOMA) experiment aboard the future ExoMars 2020 mission will continue the effort to search for organic compounds at the martian surface $[3,269]$. Compared to previous missions, samples will be collected as deep as $2 \mathrm{~m}$ below the martian surface where organic materials are expected to be preserved from the effects of radiation and oxidation occurring at the surface. This will significantly improve the capacity for the instruments to detect traces of organic molecules indigenous to Mars. In order to analyze a wide range of potential organic compounds (volatile and non-volatile compounds) present in the martian soil, the MOMA instrument utilizes both UV laser desorption/ionization (LDI) and pyrolysis GC ion trap mass spectrometry (Py-GC-ITMS).

In order to analyze refractory organic compounds, and characterize the enantiomeric ratio for chiral species, the sample can be submitted to different sample preparation processes including derivatization. With this aim, MTBSTFA [259], DMF-DMA [265], TMAH [267] were selected as the derivatization agents in MOMA. To perform derivatization and thermochemolysis on MOMA, capsules have been designed to store $15 \mu \mathrm{l}$ of each corrosive reagent dedicated to the derivatization and thermochemolysis processes. Moreover, each liquid is released at a temperature corresponding to the melting temperature of different eutectics for each wet chemistry reaction. The temperature of each eutectic was chosen to optimize the chemical reaction during the sample treatment: DMFDMA is released at $145^{\circ} \mathrm{C}$, MTBSTFA at $200^{\circ} \mathrm{C}$, and TMAH at $309^{\circ} \mathrm{C}$. Six capsules have been filled with MTBSTFA, six with DMF-DMA, and six with TMAH. Thermochemolysis and derivatization will be performed in an oven which is a part of the taping station [3] (Fig. 6). TMAH thermochemolysis will occur in three steps:

i) Oven is heated with a ramp of $135^{\circ} \mathrm{C} \mathrm{min}^{-1}$ up to $309^{\circ} \mathrm{C}$

ii) At $309^{\circ} \mathrm{C}$ derivatization capsule releases TMAH

iii) Oven is heated up to $600^{\circ} \mathrm{C}$

iv) Thermochemolysis occurs during $30 \mathrm{~s}$

v) Oven valve is opened and volatile compounds are trapped at $0^{\circ} \mathrm{C}$ on the Tenax ${ }^{\circledR}$ trap

vi) Trap is heated and volatile compounds are injected into the gas chromatographic column

The chromatographic column dedicated to the analysis of the apolar and semi-polar compounds from the thermochemolysis reaction is an MXT5 metallic column $(30 \mathrm{~m} \times 0.25 \mathrm{~mm} \times 0.25 \mu \mathrm{m})$, its stationary phase is filled with diphenyl dimethyl polysiloxane, with a low-polarity. This is a column suitable for a broad range of applications, such as the analysis of hydrocarbons, polychlorinated biphenyl (PCB) congeners, drugs, solvent impurities, pesticides, essential oils and semi-volatiles. These advantages make it possible

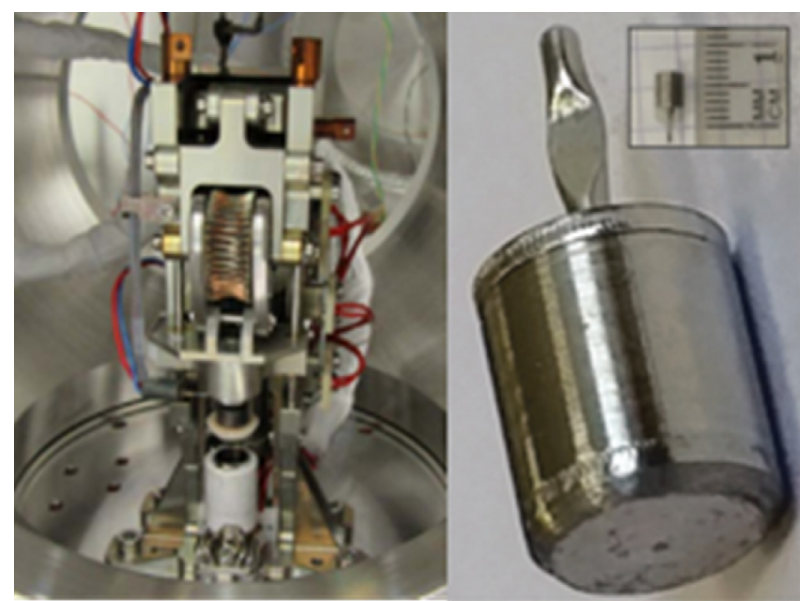

Fig. 6. Tapping station with its oven (left) and derivatization capsule (right).

to reach the target of SAM and MOMA, characterizing organic compounds at a wide range of mass weight [3].

In order to prepare future thermochemolysis experiments on Mars, authors studied the thermal degradation byproducts of Tenax ${ }^{\circledR}$ in the presence of the derivatization reagent MTBSTFA/ DMF and calcium perchlorate under SAM-like experimental conditions [270]. TMAH thermochemolysis experiments were also performed using chemical standards of seven kinds of nucleobases, important components of DNA and RNA, based on experimental conditions of the MOMA instrument [63]. In this study, properties of the TMAH thermochemolysis method were characterized and optimized for the detection of nucleobases under MOMA and SAMlike experimental conditions, as shown in Fig. 7 (adenine, thymine, uracil, cytosine, guanine, xanthine, hypoxanthine, and fatty acids). Results showed that $600^{\circ} \mathrm{C}$ is the optimal thermochemolysis temperature for all seven nucleobases. The methylated compounds and the methylation mechanisms of these seven nucleobases were analyzed and there was no overlap among these seven nucleobases in the chromatographs. In addition, the limits of detection of these seven nucleobases were investigated and quantified, showing that adenine is the most probable nucleobase to be detected on Mars if its abundance is higher than the detection limit of the device.

\subsection{Others}

In addition to the application of TMAH for the analysis of soil, coal, lacquer, lignin and plants, polymers, and in space experimentation, TMAH has been used in other fields. It can be used as a strong base catalyst for increasing the transesterification of cotton seed oil and used frying oil [117] for biodiesel production. It can be used to analyze the biotransformation of organic matter during composting of solid waste from traditional tanneries, which involves the discrimination between four main families of compounds, including aromatic compounds, lipids, polysaccharides and nitrogen-containing substances, as well as the degradation of these compounds during the composting [111]. TMAH thermochemolysis has been used to characterize a rare tiny residue in a historic 18th century pharmaceutical vessel labelled MUMIA. The residue was microscopically subsampled and analyzed by Curie point Py-GC/MS (CP-Py-GC-MS) and GC/MS. Results demonstrated that the historic 18th century MUMIA vessel contained authentic mummy material [271].

Recently, TMAH has been used by the medical community. For example, TMAH was used to liberate and purify nanoparticles from tissues and showed a good performance compared with other 
<smiles>Nc1ncnc2[nH]cnc12</smiles><smiles>Nc1ccn([Ge](Cl)(Cl)Cl)c(=O)n1</smiles><smiles>Nc1nc2[nH]cnc2c(=O)[nH]1</smiles><smiles>Cc1c[nH]c(=O)[nH]c1=O</smiles>

Thymine(T)<smiles>O=c1[nH]cnc2nc[nH]c12</smiles>

Hypoxanthine( $\mathrm{HX})$<smiles>O=c1[nH]c(=O)c2[nH]cnc2[nH]1</smiles>

Xanthine(X)

Fig. 7. The structure of nucleobases and fatty acids, adapted from Ref. [31,268].

alkaline compounds such as $\mathrm{KOH}$ and $\mathrm{NaOH}$ [272]. In this process, TMAH was used to dilute the blood sample and sonicated at $135 \mathrm{~W}$ for $1 \mathrm{~h}$ to liberate the nanoparticles and avoid nanoparticle aggregation. Researchers also studied the component of triglycerides and cholesterol in serum samples [273], preserved bone tissue [274], and the mycocerosic acid components of the phthiocerol dimycocerosate (PDIM) family of lipids [41] by using TMAH-GC/MS method. Additionally, TMAH methylation was used for the classification of bacteria based on an analysis of fatty acid methyl ester profiles [275]. TMAH-GC/MS was used to differentiate Mycobacterium tuberculosis complex (MTB) from non-tuberculous mycobacteria (NTM), tuberculostearic acid (TBSA) was used to check the sensitivity of the MS detector [276]. Results showed that the TMAHGC/MS method provided a fast and reliable method for the differentiation of MTB and NTM bacteria after culture with an accuracy of greater than 95\%; it was also used to analyze the degradation products of phthiocerol dimycocerosate waxes found in Mycobacterium tuberculosis [277].

\section{Quantitative analysis}

The TMAH-thermochemolysis method has been mainly used to qualify the organic compounds of different samples. Only a few studies have focused on the quantitation of organics. There are mainly two types of quantitative analytical methods: the external standard quantitation and internal standard quantitation. External standard quantitation is one of the most common approaches for calibration. The standard or known material is separated or external to the unknown material. The advantages of external standard calibration are that it is simple to perform this type of calibration and it can be applied to a wide variety of methods. However, it is greatly affected by the stability of the chromatographic detector system and the presence of chromatographic interferences in a sample or sample extract [278]. Table 5 shows the studies about external standard quantitative analysis of different compounds over the past 10 years. Py-GC/MS is the main instrument used for quantitative analysis of samples, including soil components, lignin analysis, and humic acid analysis. The pyrolysis experiment is mainly operated between 350 and $600^{\circ} \mathrm{C}$. However, the external standard quantitative method is not as popular as the internal standard quantitative method.

For the internal standard quantitative analysis, an internal standard calibration involves the comparison of the instrument responses from the target compounds in the sample to the responses of other standards added to the sample or sample extract before injection. It can be used to account for routine variation in the response of the chromatographic system as well as variations in the exact volume of sample or sample extract introduced into the chromatographic system; however, the internal standard should not be the compounds that could be found in the samples or its related degradation products. Compared to external standard quantitative analysis, the internal standard quantitative method demonstrates better capabilities. For example, Seddon [279] studied the quantification method of UV-B absorbing compounds in Pinus sylvestris L. pollen. The study found that the quantification method can be improved using normalization by sporopolleninbased components, including external standards (para-coumaric acid stock solution), and internal standards (Vanillic acid (4hydroxy-3-methoxybenzoic acid) and nonadecanoic acid in methanol). The THM-GC/MS method was used in order to identify the best analytical procedure to enable robust determination of UV-B absorbing compounds for future applications. Results showed that the internal standard methodology, using vanillic acid ensures more precise quantitative determination of UV-B absorbing compounds in $P$. sylvestris pollen, because the vanillic acid has a similar structure with para-coumaric (both include the combination of a carboxylic group and a phenolic hydroxyl group which react with TMAH). The similarity in chemical structure and in the reactions ensures comparable reactivities and transfer efficiencies during the analysis. The internal standard quantitative analysis that have been used in TMAH-thermochemolysis experiments are listed in Table 6. Only 14 kinds of internal standards were used to quantify organic compounds, including nonadecanoic acid, $n$-eicosane, $5 \alpha$-androstane, $n$-nonadecane, 3,5-dimethoxyphenol, $n$-decylbenzene, heptylbenzoic acid, and heneicosanoic acid, heptadecanoic acid, polymethylstyrene, linolenic acid methyl ester, n-methyl nonadecanoate, tridecanoic acid $\left(\mathrm{C}_{13}\right)$, and Naphthalene-D8. Among these, the $5 \alpha$-androstane, nonadecanoic acid and $n$-eicosane are the most popular internal standards. Dichloromethane, methanol, TMAH and hexane are the solvents of these internal standards. PyGC/MS or GC/MS is widely used for the quantitative analysis of TMAH thermochemolysis products, and the pyrolysis temperatures varied from $300^{\circ} \mathrm{C}$ up to $900^{\circ} \mathrm{C}$ according to the sample type, which included humic acids, nucleobases, lipids, and fatty acids.

However, more qualitative or semi-quantitative methods [280], rather than quantitative analysis of samples, were reported since 
Table 5

Quantification using Py-GC/MS with the external calibration curves.

\begin{tabular}{|c|c|c|c|c|c|}
\hline Sample & Chromatographic column & GC temperature program & $\mathrm{T}_{\text {Pyrolysis }}$ & Year & Publications \\
\hline $\begin{array}{l}\text { Paddy soil from Wujiang Municipality, } \\
\text { Suzhou City, Jiangsu Province, China }\end{array}$ & $\begin{array}{l}\text { Restek Rtx-5 MS fused silica capillary } \\
\text { column }(30 \mathrm{~m} \times 0.25 \mathrm{~mm} \times \text { i.d., } 0.25 \\
\mu \mathrm{m} \text { film thickness })\end{array}$ & $\begin{array}{l}1 \mathrm{~min} \text { at } 80^{\circ} \mathrm{C} \text {, from } 80 \text { to } 180^{\circ} \mathrm{C} \text { at } 4^{\circ} \mathrm{C} \\
\min ^{-1}, 180-320^{\circ} \mathrm{C} \text { at } 10^{\circ} \mathrm{C} \mathrm{min}^{-1} \text {, hold } \\
10 \mathrm{~min} \text {. }\end{array}$ & - & 2010 & [97] \\
\hline Humic samples & $\begin{array}{l}\text { Fused-silica capillary column (Restek } \\
\text { Rtx@-5MS, } 30 \text { m length } \times 0.25 \mathrm{~mm} \text { I.D. } \\
\times 0.25 \mu \mathrm{m} \text { film thickness) }\end{array}$ & $\begin{array}{l}\text { From } 100^{\circ} \mathrm{C} \text { to } 300^{\circ} \mathrm{C} \text { at } 4^{\circ} \mathrm{C} \mathrm{min}^{-1} \text { and } \\
\text { hold } 20 \mathrm{~min} \text {. }\end{array}$ & $600^{\circ} \mathrm{C}$ & 2012 & [98] \\
\hline $\begin{array}{l}\text { Lignin standards, lipid standards and } \\
\text { alkane standards }\end{array}$ & $\begin{array}{l}\text { BPX-5 column }(60 \mathrm{~m} \times 0.25 \mathrm{~mm} \text {, film } \\
\text { thickness } 0.25 \mu \mathrm{m})\end{array}$ & $\begin{array}{l}5 \mathrm{~min} \text { at } 40^{\circ} \mathrm{C}, 5^{\circ} \mathrm{C} \mathrm{min}^{-1} \text { to } 270^{\circ} \mathrm{C} \text { and } \\
30^{\circ} \mathrm{C} \mathrm{min}^{-1} \text { to a } 300^{\circ} \mathrm{C} \text { (hold } 10 \mathrm{~min} \text { ). }\end{array}$ & $590^{\circ} \mathrm{C}$ & 2012 & [71] \\
\hline $\begin{array}{l}\text { Heptadecane, tridecanoic acid, } \\
\text { cinnamic acid, octadecanol, 16- } \\
\text { hydroxy hexadecanoic acid, } \\
\text { docosandioic acid, and beta- } \\
\text { sitosterol. }\end{array}$ & $\begin{array}{l}\text { RTX-5MS WCOT capillary column } \\
\text { (Restek, } 30 \mathrm{~m} \times 0.25 \mathrm{~mm} \text { i.d.; film } \\
\text { thickness }=0.25 \mu \mathrm{m} \text { ) }\end{array}$ & $\begin{array}{l}1 \mathrm{~min} \text { at } 60^{\circ} \mathrm{C} \text { raise at } 7^{\circ} \mathrm{C} \mathrm{min}^{-1} \text { to } \\
100^{\circ} \mathrm{C} \text { and then at } 4^{\circ} \mathrm{C} \mathrm{min}^{-1} \text { to } 320^{\circ} \mathrm{C} \\
\text { (hold } 5 \mathrm{~min} \text { ). }\end{array}$ & $400^{\circ} \mathrm{C}$ & $\begin{array}{l}2012 \\
2013\end{array}$ & {$[62,89]$} \\
\hline Bisphenol A and bisphenol S & $\begin{array}{l}\text { A DB5 fused silica capillary column ( } 30 \\
\mathrm{~m} \times 0.25 \mathrm{~mm} \text { i.d., } 0.25 \mu \mathrm{m} \text { film } \\
\text { thickness) }\end{array}$ & $\begin{array}{l}100^{\circ} \mathrm{C}-250^{\circ} \mathrm{C} \text { at } 10^{\circ} \mathrm{C} \mathrm{min}^{-1} \text {, and then } \\
\text { to } 275^{\circ} \mathrm{C} \text { at } 5^{\circ} \mathrm{C} / \mathrm{min} \text { then at } 15^{\circ} \mathrm{C} \mathrm{min}^{-1} \\
\text { to } 320^{\circ} \mathrm{C} \text { (hold for } 5 \mathrm{~min} \text { ). }\end{array}$ & $\begin{array}{l}400^{\circ} \mathrm{C} \\
0.5 \mathrm{~s}\end{array}$ & 2013 & [17] \\
\hline Gallic acid & $\begin{array}{l}\text { A metal capillary column (Frontier Lab., } \\
\text { Ultra ALLOY-5 }, 30 \mathrm{~m} \times 0.25 \mathrm{~mm} \text { ID) } \\
\text { coated with poly( } 5 \% \text {-diphenyl-95\%- } \\
\text { dimethyl) siloxane }(0.25 \mu \mathrm{m} \text { film } \\
\text { thickness) }\end{array}$ & $\begin{array}{l}50^{\circ} \mathrm{C}-300^{\circ} \mathrm{C} \text { at a rate of } 5 \text { or } 10^{\circ} \mathrm{C} \\
\mathrm{min}^{-1} .\end{array}$ & $350^{\circ} \mathrm{C}$ & 2015 & [19] \\
\hline Polymer standards & $\begin{array}{l}\text { DB5 (J and } \mathrm{W} \text { ); } 30 \mathrm{~m} \times 0.25 \mathrm{~mm} \text { ID, film } \\
\text { thickness } 0.25 \mu \mathrm{m}\end{array}$ & $\begin{array}{l}50^{\circ} \mathrm{C}(1 \mathrm{~min}) \text { to } 310^{\circ} \mathrm{C}(10 \mathrm{~min}) \text { at } 3^{\circ} \mathrm{C} \\
\mathrm{min}^{-1}\end{array}$ & $590^{\circ} \mathrm{C}$ & 2017 & [76] \\
\hline $\begin{array}{l}\text { Tridecanoic acid, octadecanol, } 16- \\
\text { hydroxyhexadecanoic acid, } \\
\text { docosanoic acid, } \beta \text {-sitosterol, and } \\
\text { cinnamic }\end{array}$ & $\begin{array}{l}\text { Rtx-5MS WCOT }(30 \mathrm{~m} \times 0.25 \mathrm{~mm} \text { id, } \\
0.25 \mu \mathrm{m})\end{array}$ & $\begin{array}{l}60^{\circ} \mathrm{C}(1 \mathrm{~min}) \text { to } 100^{\circ} \mathrm{C} \text { at } 7^{\circ} \mathrm{C} \min ^{-1} \text { and } \\
\text { then at } 4^{\circ} \mathrm{C} \min ^{-1} \text { to } 320^{\circ} \mathrm{C} \text { (hold } 10 \\
\text { min) }\end{array}$ & $400^{\circ} \mathrm{C}, 30 \mathrm{~min}$ & $\begin{array}{l}2013 \\
2014\end{array}$ & {$[90,91]$} \\
\hline
\end{tabular}

Table 6

Quantification using internal standards.

\begin{tabular}{|c|c|c|c|c|c|c|c|}
\hline No. & Internal standard & Solvent & Sample & $\begin{array}{l}\text { Analysis } \\
\text { method }\end{array}$ & $\mathrm{T}_{\text {Pyrolysis }}$ & Year & Publications \\
\hline \multirow[t]{4}{*}{1.} & Nonadecanoic acid & $\begin{array}{l}\text { A mixture of acetone } \\
\text { and methanol }(v / v=3 / 2)\end{array}$ & $\begin{array}{l}\text { Fertilizer samples, humic } \\
\text { acid }\end{array}$ & Py-GC/MS & $550^{\circ} \mathrm{C}, 0.4$ or $1 \mathrm{~min}$ & $\begin{array}{l}2009 \\
2011 \\
2012 \\
2016\end{array}$ & [84-87] \\
\hline & Nonadecanoic acid & Hexane & $\begin{array}{l}\text { Sediment sample (lignin } \\
\text { analysis) }\end{array}$ & Py-GC/MS & $590^{\circ} \mathrm{C}, 20 \mathrm{~s}$ & 2014 & [77] \\
\hline & Nonadecanoic acid & Acetone & $\begin{array}{l}\text { Humic acid and fulvic acid } \\
\text { samples }\end{array}$ & Py-GC/MS & $550^{\circ} \mathrm{C}, 0.4 \mathrm{~min}$ & 2018 & [102] \\
\hline & Nonadecanoic- $\mathrm{d}_{37}$ acid & Ethyl acetate & Sterols and stanols & GC/MS & $300^{\circ} \mathrm{C}$ & $\begin{array}{l}2017 \\
2018\end{array}$ & {$[240,243]$} \\
\hline \multirow[t]{4}{*}{2.} & $n$-Eicosane & TMAH & $\begin{array}{l}\text { Freshly fallen litter and } \\
\text { litter from litter bags }\end{array}$ & Py-GC/MS & $350^{\circ} \mathrm{C}$ & 2011 & {$[39,169]$} \\
\hline & $n$-Eicosane & 25\% (wt\%) TMAH methanol & Phenolic compounds & GC/MS & $250 \pm 2^{\circ} \mathrm{C}$ for $30 \mathrm{~min}$ & 2012 & [358] \\
\hline & $n$-Eicosane $\left(C_{20}\right)$ & EtOAc & Suberan & $\mathrm{Py}-\mathrm{GC} / \mathrm{MS}$ & $610^{\circ} \mathrm{C}, 15 \mathrm{~s}$ & 2013 & [184] \\
\hline & $n$-Eicosane & Hexane & Lipid extraction of soil & GC/MS & $280^{\circ} \mathrm{C}$ & 2015 & [357] \\
\hline \multirow[t]{5}{*}{3.} & $5 \alpha$-Androstane & TMAH & Peat litter and litterbag & $\mathrm{Py}-\mathrm{GC} / \mathrm{MS}$ & $450^{\circ} \mathrm{C}$ & 2010 & [178] \\
\hline & $5 \alpha$-Androstane & Dichloromethane & Wheat straw & Py-GC/MS & $600^{\circ} \mathrm{C}$ & 2012 & {$[80]$} \\
\hline & $5 \alpha$-Androstane & TMAH (25\%; w/w) & $\begin{array}{l}\text { Living plant tissues and } \\
\text { litters }\end{array}$ & Py-GC/MS & $610^{\circ} \mathrm{C}, 10 \mathrm{~s}$ & 2013 & [81] \\
\hline & $5 \alpha$-Androstane & TMAH $(25 \%, w / w)$ & $\begin{array}{l}\text { Eight peat cores, sphagnum } \\
\text { acid }\end{array}$ & Py-GC/MS & $610^{\circ} \mathrm{C}, 10 \mathrm{~s}$ & 2013 & [96] \\
\hline & $5 \alpha$-Androstane & Cyclohexane & Soil samples & $\mathrm{Py}-\mathrm{GC} / \mathrm{MS}$ & $600^{\circ} \mathrm{C}, 5 \mathrm{~s}$. & 2019 & [75] \\
\hline \multirow[t]{2}{*}{4.} & $n$-Nonadecane & Dichloromethane & $\begin{array}{l}\text { Methylated lignin } \\
\text { derivatives }\end{array}$ & Py, GC/MS & - & 1996 & [9] \\
\hline & $n$-Nonadecane & - & Lignite & Py-GC/MS & $400^{\circ} \mathrm{C}$ & 2017 & {$[50,51]$} \\
\hline 5. & 3,5-dimethoxyphenol & - & Softwood lignin & Py-GC/MS & $\begin{array}{l}210^{\circ} \mathrm{C}(3 \mathrm{~min}), \\
610^{\circ} \mathrm{C}(1 \mathrm{~min}), \text { and hold } \\
56 \mathrm{~min}\end{array}$ & 2011 & [163] \\
\hline 6. & $n$-Decylbenzene & TMAH & Winery wastewaters & Py-GC/MS & $\begin{array}{l}\text { Pretreatment } 340^{\circ} \mathrm{C} \text { then } \\
\text { flash to } 720^{\circ} \mathrm{C}\end{array}$ & 2012 & [359] \\
\hline \multirow[t]{2}{*}{7.} & Heptylbenzoic acid & Methanol & Fatty acids & GC/MS & - & $\begin{array}{l}2012 \\
2010\end{array}$ & {$[360,361]$} \\
\hline & Heptylbenzoic acid & - & $\begin{array}{l}\text { Components of the "free" } \\
\text { bitumen }\end{array}$ & Py-GC/MS & $\begin{array}{l}300^{\circ} \mathrm{C}(\mathrm{S} 1), 600^{\circ} \mathrm{C}(\mathrm{S} 2), \\
390^{\circ} \mathrm{C}(\mathrm{S} 3)\end{array}$ & 2013 & [195] \\
\hline 8. & Heneicosanoic acid & Methanol or dichloromethane & $\begin{array}{l}\text { Guaiacyl palmitate and 2- } \\
\text { nonyl palmitate }\end{array}$ & Py-GC/MS & $600^{\circ} \mathrm{C}, 2 \mathrm{~s}$ & 2013 & [29] \\
\hline 9. & Heptadecanoic acid & TMAH in methanol & $\begin{array}{l}\text { Outer surfaces of } \\
\text { archaeological pottery }\end{array}$ & Py-GC/MS & $480^{\circ} \mathrm{C}$ & 2017 & [223] \\
\hline 10. & Polymethylstyrene & Dichloromethane & asphaltene powders & $\mathrm{Py}-\mathrm{GC} / \mathrm{MS}$ & $650^{\circ} \mathrm{C}$ & 2015 & [27] \\
\hline 11. & Linolenic acid methyl ester & Ethyl acetate & Lignin & Py-GC/MS & - & 2017 & [179] \\
\hline
\end{tabular}


Table 6 (continued)

\begin{tabular}{|c|c|c|c|c|c|c|c|}
\hline No. & Internal standard & Solvent & Sample & $\begin{array}{l}\text { Analysis } \\
\text { method }\end{array}$ & $\mathrm{T}_{\text {Pyrolysis }}$ & Year & Publications \\
\hline 12. & n-Methyl- nonadecanoate & Dichloromethane & $\begin{array}{l}\text { Lignin, carbohydrates, and } \\
\text { lipids }\end{array}$ & GC/MS & $250^{\circ} \mathrm{C}$ & 2018 & [36] \\
\hline 13. & Tridecanoic acid (C13) & $5 \%$ methanolic solution of TMAH & saturated fatty acid (SFA) & Py-GC/MS & $360^{\circ} \mathrm{C}-700^{\circ} \mathrm{C}(3 \mathrm{~min})$ & 2019 & [35] \\
\hline 14. & Naphthalene-D8 & Dichloromethane & Nucleobases & Py-GC/MS & $600^{\circ} \mathrm{C}$, flash pyrolysis & 2019 & [31] \\
\hline 15 & - & - & Amino acids & Py-GC/MS & $400,500,700$, and $900^{\circ} \mathrm{C}$ & 2010, 2011 & {$[64,110]$} \\
\hline
\end{tabular}

2010; only about $14 \%$ of these studies did quantitative analysis. Therefore, more efforts need to be put forward to develop a robust quantitative analysis method in the future.

\section{The reactional mechanisms involved in TMAH thermochemolysis}

\subsection{The mechanism of TMAH thermochemolysis}

TMAH works as a methylation agent boosting the cleavage of macromolecules during the TMAH thermochemolysis process. The TMAH thermochemolysis mechanism of using a certain compound with an acidic functional group was proposed by Kossa et al., in 1979 [281]. Trimethylamine was formed by the nucleonic attack by $\mathrm{OH}$ or methoxide ion. The methyl functional group can replace the active hydrogen of target compounds, such as the replacement of labile hydrogen in nucleobases [31]. A hydrolysis step was added by Challinor [282] where the $\mathrm{OH}$ - from the TMAH could cause a cleavage of ester or ether bonds. The Kossa methylation theory has been widely accepted, as shown in Fig. 8. For example, Templier [283] studied the pyrolysis of 16 kinds of dipeptides with TMAH by $\mathrm{GC} / \mathrm{MS}$, in order to evaluate the effect of the peptide bond on the pyrolysis products released from proteinaceous materials. Results show that the direct methylation of peptide is the main pathway due to the presence of TMAH, along with the formation of piperazine-2,5-diones (DKPs) previously observed from single amino acids. In addition, the $\mathrm{C}$ - or $\mathrm{N}$-terminal position of the amino acids is of importance for the formation of different products, such as imidazolidinedione. However, rarely new theories about the mechanism of TMAH thermochemolysis have been developed. There are mainly two methods to do TMAH thermochemolysis, including off-line and on-line thermochemolysis, TMAH has to be mixed with samples in both processes, which means that the methylation process happens when a sample is mixed with TMAH. However, it should be studied if TMAH could methylate a functional group such as $-\mathrm{NH}_{2}$ in the gas phase. If the methyl functional group from TMAH in the gas phase could methylate samples, we could try to do further research in utilizing the derivatization reagent in gaseous form. New derivatization reagents need to be developed, such as derivatization substances in the solid or gas phase, which could increase the ease of delivery.

\subsection{The mechanism of TMAH degradation}

During the thermochemolysis process, TMAH undergoes two different pathways of degradation, the $\mathrm{SN}_{2}$ pathway and the ylide pathway. The $\mathrm{SN}_{2}$ pathway is the nucleophilic attack by $\mathrm{OH}^{-}$on the $\mathrm{CH}_{3}$ group that produces trimethylamine and dimethyl ether [284]. For example, Macomber [285] studied the thermal decomposition pathways of TMAH using DSC, TG, and evolved gas analysis (EGA), finding that trimethylamine, methanol and dimethyl ether were the main byproducts. The methoxide formed in this way then reacts with $\left[\mathrm{Me}_{4} \mathrm{~N}\right]^{+}$via an $\mathrm{SN}_{2}$ process to generate dimethyl ester. The ylide pathway is the decomposition of TMAH to give trimethylamine and dimethyl ether, caused by the initial removal of the proton from the quaternary ammonium salt followed by the decomposition of ylides [286]. The abstraction of the $\alpha$-proton to generate a nitrogen ylide is a very important degradation mechanism for methyl ammonium species. Deprotonation of the tetramethyl ammonium ion by hydroxide establishes a rapid equilibrium between tetramethylammonium ions and the nitrogen ylide species and water that scrambles the deuterium with the proton in the methyl groups.

However, some researchers think that the ylide pathway is more reasonable than the $\mathrm{SN}_{2}$ pathway [287]. The stability of tetramethylammonium $\left(\left[\mathrm{N}\left(\mathrm{CH}_{3}\right)_{4}{ }^{+}\right]\right)$under aqueous conditions in the presence of the $\mathrm{OH}$ ion was studied. Results showed that the ylide mechanism plays a crucial role in the decomposition of TMAH demonstrated by the TG-MS experiments which verified the H-D exchange. On the other side, the activation barrier for the ylide reaction is lower than for the $\mathrm{SN}_{2}$ pathway based on the calculations of the density functional theory. Also, the ylide pathway can give rise to unstable intermediates with side reactions including the Stevens rearrangement reaction [288], Sommelet-Hauser rearrangement, and Hofmann elimination [289]. Hofmann elimination is a vulnerable pathway for degradation of $n$-alkyl TMA ${ }^{+}$ cations [290]; the barrier is dependent on the carbon chain length because of steric interference and the number of hydrogens susceptible to Hofmann elimination [290]. On the other side, the Hofmann elimination is the preferred decomposition pathway for ammonium cations bearing $\beta$-hydrogens, and ylide formation scrambles protons from water into trimethylamine which is formed with a low activation barrier [291].

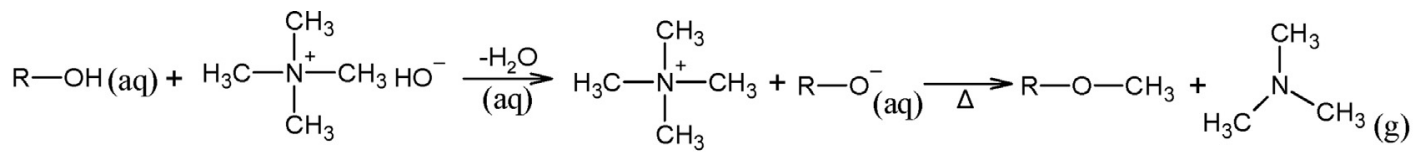

$\mathrm{HO}^{-}+\mathrm{A}-\mathrm{B}(\mathrm{aq}) \longrightarrow \mathrm{A}^{-}(\mathrm{aq})+\mathrm{B}-\mathrm{OH}(\mathrm{aq})$ or $\longrightarrow \mathrm{B}^{-}+\mathrm{A}-\mathrm{OH}$ (A-B reperesents the hydrolysable analyte molecule)

Fig. 8. The mechanism of TMAH thermochemolysis, adapted from Ref. [14,281,282]. 
However, the degradation mechanism of TMAH has been studied at low temperatures (about $200^{\circ} \mathrm{C}$ ) and TMAH has been used extensively at high temperatures such as $600^{\circ} \mathrm{C}$. At this high temperature the degradation of TMAH could be different and the radical mechanisms that commonly occur at high pyrolysis temperatures should be studied. Moreover, TMAH biodegradation and the degradation under ultraviolet (UV) light have been investigated. For example, Wang [292] studied the oxidative degradation of a TMAH solution with UV light activated persulfate $\left(\mathrm{S}_{2} \mathrm{O}_{8}{ }^{2-}\right)$. The effect of conditions such as the $\mathrm{pH}$, dosages of persulfate, UV intensities and system temperatures has been studied. Results showed that the TMAH decay increased with the increasing persulfate dosage; when the persulfate concentration was $50 \mathrm{mM}$, the highest degradation was observed. Higher reaction temperatures and strong UV irradiation increased the degradation of TMAH. Nitrate and ammonium are the degradation products of TMAH, which means that the demethylation mechanism is the main degradation pathway. The biodegradation of TMAH has a similar mechanism. The most proposed metabolic pathway for TMAH is that TMAH is first degraded into trimethylamine and methanol. In biological and chemical oxidative decompositions, it is proposed that TMAH will be decomposed into formaldehyde and ammonium. Finally, the TMAH will be decomposed to $\mathrm{N}_{2}, \mathrm{H}_{2} \mathrm{O}$, and $\mathrm{CO}_{2}$ by microorganism strains or thermal decomposition and oxidation catalysts [293], processes which could help to understand the TMAH degradation process during pyrolysis. However, the mechanism of TMAH degradation at high temperature as well as the byproducts of TMAH degradation still needs to be studied.

\section{Conclusions and future trends}

TMAH thermochemolysis has been widely used in various fields in recent years, especially for the analysis of organic compounds present in soils, lacquers, lignin and other related samples. TMAH thermochemolysis has become more and more popular for the study of artwork during the last ten years. The organic substances that could be analyzed by TMAH thermochemolysis include saturated and unsaturated long-chain fatty acids, humic acids, phenolic structures, alcohols, polymers containing aldehyde, carboxyl, ether, and ester functional groups, such as lignin, lignocelluse, and resins, and unnatural polymers such as polyethylene terephthalate (PET), polycarbonate (PC), poly(methyl methacrylate) (PMMA), poly(alkyl methacrylate), polyamide 6(PA6), and nylon, etc. These are the potential compounds that could be detected if related compounds exist on Mars.

This review gives an overview of the studies about TMAH thermochemolysis; however, most of the studies focus on the qualitative analysis of organic compounds, while the quantitative analysis of organic compounds and the use of internal or external standards require more study. For example, the quantitative analysis of lacquers in ancient artwork is useful for the repair and inheritance of these relics. On the other hand, the quantitative method needs to be developed, especially new internal standards. TMAH thermochemolysis has been used for the characterization of organics in soil samples. There is also ongoing development of the TMAH thermochemolysis technique for the analysis of organic compounds by space experiments. Therefore, more studies need to be done under space conditions. It is useful to combine chemical and biological data on organic compounds in order to understand the properties of life on Earth or potentially on other planets; for example, TMAH studies can investigate if pretreatment of the TMAH chemical reagent will have an effect on microorganisms in a soil sample or the genetic information fundamental to life. An understanding of the relationship between organic matter, the parentage of that organic matter, and the environment across geological timescales can be constructed in order to improve our understanding of the origin of life. To achieve this goal, analytical methods and instrumentation must be developed which combine chemical and biological characterization methods. For example, most of the mass spectrometry used in previous studies targets compounds in a mass range below $500 \mathrm{u}$. An effective separation and detection device could be developed in the future which surpasses this range. Finally, the mechanism of TMAH thermochemolysis-as a methylation process-is well known; however, the degradation products of TMAH reagents at high temperatures and the effect of minerals on TMAH degradation or TMAH thermochemolysis should be studied, in order to optimize the experimental conditions of SAM and MOMA. In parallel, in situ technologies based on TMAH thermochemolysis and analysis are under development, and the application of TMAH thermochemolysis on the detection of organic compounds for space exploration is a new trend.

\section{Acknowledgements}

The authors are grateful for the support of the French Space Agency (Centre National d'Etudes Spatiales) and SAM/MOMA funding. Thanks for the CSC scholarship (201701810036).

\section{References}

[1] P.G. Simmonds, Organic analysis by pyrolys is-gas chromatography-mass spectrometry a candidate experiment for the biological exploration of mars, J. Chromatogr. Sci. 7 (1969) 36-41.

[2] O. Botta, J.L. Bada, Extraterrestrial organic compounds in meteorites, Surv. Geophys. 23 (2002) 411-467.

[3] F. Goesmann, W.B. Brinckerhoff, F. Raulin, W. Goetz, R.M. Danell, S.A. Getty, et al., The mars organic molecule analyzer (MOMA) instrument: characterization of organic material in martian sediments, Astrobiology 17 (2017) 655-685.

[4] P.R. Solomon, M.A. Serio, E.M. Suuberg, Coal pyrolysis: experiments, kinetic rates and mechanisms, Prog. Energy Combust. Sci. 18 (1992) 133-220.

[5] X. Li, J. ichiro Hayashi, C.Z. Li, FT-Raman spectroscopic study of the evolution of char structure during the pyrolysis of a Victorian brown coal, Fuel 85 (2006) 1700-1707.

[6] H. Yang, R. Yan, H. Chen, D.H. Lee, C. Zheng, Characteristics of hemicellulose, cellulose and lignin pyrolysis, Fuel 86 (2007) 1781-1788.

[7] H.Y. Cai, A.J. Güell, I.N. Chatzakis, J.Y. Lim, D.R. Dugwell, R. Kandiyoti, Combustion reactivity and morphological change in coal chars: effect of pyrolysis temperature, heating rate and pressure, Fuel 75 (1996) 15-24.

[8] K.R. Doolan, J.C. Mackie, R.J. Tyler, Coal flash pyrolysis: secondary cracking of tar vapours in the range 870-2000 K, Fuel 66 (1987) 572-578.

[9] C. Schummer, O. Delhomme, B.M.R. Appenzeller, R. Wennig, M. Millet, Comparison of MTBSTFA and BSTFA in derivatization reactions of polar compounds prior to GC/MS analysis, Talanta 77 (2009) 1473-1482.

[10] L. Degani, C. Riedo, O. Chiantore, Identification of natural indigo in historica textiles by GC-MS, Anal. Bioanal. Chem. 407 (2015) 1695-1704.

[11] K. Hiroyuki, Derivatization reactions for the determination of amines by gas chromatography and their applications in environmental analysis, J. Chromatogr., A 733 (1996) 19-34.

[12] C. Freissinet, M. Millan, D.P. Glavin, X. Li, A. Grubisic, J.E. Eigenbrode, et al., Investigating the effects of gamma radiation on selected chemicals for use in biosignature detection instruments on the surface of Jupiter's moon Europa, Planet, Space Sci 175 (2019) 1-12.

[13] J.M. Challinor, A pyrolysis-derivatisation-gas chromatography technique for the structural elucidation of some synthetic polymers, J. Anal. Appl. Pyrolysis 16 (1989) 323-333.

[14] F. Shadkami, R. Helleur, Recent applications in analytical thermochemolysis, J. Anal. Appl. Pyrolysis 89 (2010) 2-16.

[15] E.W. Robb, J.J. Westbrook, Preparation of methyl esters for gas liquid chromatography of acids by pyrolysis of tetramethylammonium salts, Anal. Chem. 35 (1963) 1644-1647.

[16] Y. Sun, C. Tang, X. Wu, Z. Pan, L. Wang, Characterization of alkylphenol components in ginkgo biloba sarcotesta by thermochemolysis-gas chromatography/mass spectrometry in the presence of trimethylsulfonium hydroxide, Chromatographia 75 (2012) 387-395.

[17] V. Becerra, J. Odermatt, Interferences in the direct quantification of bisphenol S in paper by means of thermochemolysis, J. Chromatogr., A 1275 (2013) $70-77$.

[18] K. Takeuchi, H. Aoi, H. Ohtani, Precise compositional analysis of styrene/butyl acrylate/methacrylic acid terpolymer by two-step reactive pyrolysis-gas 
chromatography with tetramethylammonium acetate, J. Anal. Appl. Pyrolysis 113 (2015) 22-26.

[19] Y. Ishida, T. Hirota, S. Sato, M. Kamegai, S.K. Kim, S.Y. Park, et al., Discriminative analysis of free and esterified gallic acids in acorn shells by thermochemolysis-gas chromatography/mass spectrometry in the presence of organic alkalis, J. Anal. Appl. Pyrolysis 116 (2015) 114-119.

[20] Y. Sun, X. Wang, Y. Huang, Z. Pan, L. Wang, Derivatization following hollowfiber microextraction with tetramethylammonium acetate as a dual-function reagent for the determination of benzoic acid and sorbic acid by GC, J. Separ. Sci. 36 (2013) 2268-2276.

[21] E. Manzano, L.R. Rodriguez-Simón, N. Navas, R. Checa-Moreno, M. RomeroGámez, L.F. Capitan-Vallvey, Study of the GC-MS determination of the palmitic-stearic acid ratio for the characterisation of drying oil in painting: La Encarnación by Alonso Cano as a case study, Talanta 84 (2011) 1148-1154.

[22] E. Jakab, Á. Bora, Z. Sebestyén, J. Borsa, Thermal decomposition of chemically treated cellulosic fibers, J. Therm. Anal. Calorim. 132 (2018) 433-443.

[23] J. Poerschmann, L. Schultze-Nobre, Rapid screening of phytoremediation effluents by off-line tetramethylammonium hydroxide assisted thermochemolysis, Sci. Total Environ. 518-519 (2015) 371-377.

[24] A.M. Tadini, G. Pantano, A.L. de Toffoli, B. Fontaine, R. Spaccini, A. Piccolo, et al., Off-line TMAH-GC/MS and NMR characterization of humic substances extracted from river sediments of northwestern São Paulo under different soil uses, Sci. Total Environ. 506-507 (2015) 234-240.

[25] X. Zang, J.C. Brown, J.D.H. Van Heemst, A. Palumbo, P.G. Hatcher, Characterization of amino acids and proteinaceous materials using online tetramethylammonium hydroxide (TMAH) thermochemolysis and gas chromatography-mass spectrometry technique, J. Anal. Appl. Pyrolysis 61 (2001) 181-193.

[26] J.P. Liu, S.A. Kuehl, A.C. Pierce, J. Williams, N.E. Blair, C. Harris, et al., Fate of ayeyarwady and thanlwin rivers sediments in the andaman sea and bay of bengal, Mar. Geol. 423 (2020) 106137.

[27] Y. Pan, Y. Liao, Y. Zheng, Effect of biodegradation on the molecular composition and structure of asphaltenes: clues from quantitative Py-GC and THMGC, Org. Geochem. 86 (2015) 32-44.

[28] Veenhoven J., Saverwyns S., Van Bommel M., Lynen F., Evaluation of on-line derivatization techniques using TMAH and HMDS for the comprehensive analysis of anacardiaceae thermosetting lacquer polymers using pyrolysisGC/MS and deconvolution.

[29] T. Ohra-Aho, J. Ropponen, T. Tamminen, Thermochemolysis using TMAAC and TMAH reagents as means to differentiate between free acids and esters, J. Anal. Appl. Pyrolysis (2013) 31-35.

[30] S.L. Mason, T.R. Filley, G.D. Abbott, A comparative study of the molecular composition of a grassland soil with adjacent unforested and afforested moorland ecosystems, Org. Geochem. 42 (2012) 1519-1528.

[31] Y. He, A. Buch, M. Morisson, C. Szopa, C. Freissinet, A. Williams, et al, Application of TMAH thermochemolysis to the detection of nucleobases: application to the MOMA and SAM space experiment, Talanta 204 (2019) $802-811$.

[32] S. Baidurah, Y. Kubo, M.K. Kuno, K.K. Kodera, Y.I. Ishida, T. Yamane, et al., Rapid and direct compositional analysis of poly ( 3-hydroxybutyrate- co -3hydroxyvalerate ) in whole bacterial cells by thermally assisted hydrolysis and methylation - gas chromatography, Anal. Sci. 31 (2015) 79-83.

[33] Y.S. Khok, M. Suwa, H. Ito, M. Hazwan Hussin, Y. Ishida, K. Sudesh, et al., Comparison of quantification methods and subsequent characterization of polyhydroxybutyrate film sample utilizing pretreated cane molasses as carbon source Comparison of quantification methods and subsequent characterization of polyhydroxybutyrate film sa, IOP Conf. Ser. Mater. Sci. Eng 716 (2020), 012013.

[34] A. Andrade-Eiroa, M. Canle, V. Leroy-Cancellieri, V. Cerdà, Solid-phase extraction of organic compounds: a critical review (Part I), TrAC Trends Anal. Chem. (Reference Ed.) 80 (2016) 641-654.

[35] L. Baij, A. Astefanei, J. Hermans, F. Brinkhuis, H. Groenewegen, L. Chassouant, et al., Solvent-mediated extraction of fatty acids in bilayer oil paint models: a comparative analysis of solvent application methods, Herit. Sci. 7 (2019) $1-8$.

[36] K. Younes, L. Grasset, Comparison of thermochemolysis and classical chemical degradation and extraction methods for the analysis of carbohydrates, lignin and lipids in a peat bog, J. Anal. Appl. Pyrolysis 134 (2018) $61-72$.

[37] O. Bertrand, L. Mansuy-Huault, E. Montargès-Pelletier, P. Faure, B. Losson, J. Argant, et al., Recent vegetation history from a swampy environment to a pond based on macromolecular organic matter (lignin and fatty acids) and pollen sedimentary records, Org. Geochem. 64 (2013) 47-57.

[38] P.R. Mahaffy, C.R. Webster, M. Cabane, P.G. Conrad, P. Coll, S.K. Atreya, et al., The sample analysis at mars investigation and instrument suite, Space Sci. Rev. 170 (2012) 401-478.

[39] T. Klotzbücher, T.R. Filley, K. Kaiser, K. Kalbitz, A study of lignin degradation in leaf and needle litter using 13 C-labelled tetramethylammonium hydroxide ( TMAH ) thermochemolysis : comparison with CuO oxidation and van Soest methods, Org. Geochem. 42 (2011) 1271-1278.

[40] N.A. Dang, M. Mourão, S. Kuijper, E. Walters, H.G. Janssen, A.H.J. Kolk, Direct detection of Mycobacterium tuberculosis in sputum using combined solid phase extraction-gas chromatography-mass spectrometry, J. Chromatogr. B Anal. Technol. Biomed. Life Sci. 986-987 (2015) 115-122.
[41] D.M. O'Sullivan, S.C. Nicoara, R. Mutetwa, S. Mungofa, O.Y. Lee, D.E. Minnikin, et al., Detection of mycobacterium tuberculosis in sputum by gas chromatography-mass spectrometry of methyl mycocerosates released by thermochemolysis, PloS One 7 (2012), e32836.

[42] Z. Yun, B. He, Z. Wang, T. Wang, G. Jiang, Evaluation of different extraction procedures for determination of organic Mercury species in petroleum by high performance liquid chromatography coupled with cold vapor atomic fluorescence spectrometry, Talanta 106 (2013) 60-65.

[43] A. Buch, D.P. Glavin, R. Sternberg, C. Szopa, C. Rodier, R. Navarro-González, et al., A new extraction technique for in situ analyses of amino and carboxylic acids on Mars by gas chromatography mass spectrometry, Planet. Space Sci. 54 (2006) 1592-1599.

[44] A. Mojarro, G. Ruvkun, M.T. Zuber, C.E. Carr, Nucleic acid extraction and sequencing from low-biomass synthetic Mars analog soils for in situ life detection, Astrobiology 17 (2017) 747-760.

[45] A. Mojarro, J. Hachey, R. Bailey, M. Brown, R. Doebler, G. Ruvkun, et al., Nucleic acid extraction and sequencing from low-biomass synthetic Mars analog soils for in situ life detection, Astrobiology 19 (2019) 1139-1152.

[46] G. Yang, H. Tazoe, M. Yamada, Improved approach for routine monitoring of 129I activity and 129I/127I atom ratio in environmental samples using TMAH extraction and ICP-MS/MS, Anal. Chim. Acta 1008 (2018) 66-73.

[47] O.S. Humphrey, S.D. Young, E.H. Bailey, N.M.J. Crout, E.L. Ander, M.J. Watts, Iodine soil dynamics and methods of measurement: a review, Environ. Sci. Process. Impacts. 20 (2018) 288-310.

[48] S. Öztan, R.A. Düring, Microwave assisted EDTA extraction - determination of pseudo total contents of distinct trace elements in solid environmental matrices, Talanta 99 (2012) 594-602.

[49] Y. He, R. Zhao, L. Yan, Y. Bai, F. Li, The effect of low molecular weight compounds in coal on the formation of light aromatics during coal pyrolysis, J. Anal. Appl. Pyrolysis 123 (2017) 49-55.

[50] L. Doskočil, V. Enev, L. Grasset, J. Wasserbauer, The characterization of South Moravian lignite in its natural and treated forms using thermal degradation methods, J. Anal. Appl. Pyrolysis 128 (2017) 83-91.

[51] L. Doskočil, L. Grasset, V. Enev, L. Kalina, M. Pekař, Study of water-extractable fractions from South Moravian lignite, Environ. Earth Sci. 73 (2015) $3873-3885$.

[52] F.Z. El Ouaqoudi, A. Meddich, L. Lemée, A. Amblès, M. Hafidi, Assessment of compost-derived humic acids structure from ligno-cellulose waste by TMAH-thermochemolysis, Waste and Biomass Valorization 10 (2019) $2661-2672$.

[53] A. Andrade-Eiroa, V. Leroy, P. Dagaut, Y. Bedjanian, Determination of polycyclic aromatic hydrocarbons in kerosene and bio-kerosene soot, Chemosphere 78 (2010) 1342-1349.

[54] N.V. Heuett, C.E. Ramirez, A. Fernandez, P.R. Gardinali, Analysis of drugs of abuse by online SPE-LC high resolution mass spectrometry: communal assessment of consumption, Sci. Total Environ. 511 (2015) 319-330.

[55] X. Zhang, D. Zhu, C. Huang, Y. Sun, Y.I. Lee, Sensitive detection of bisphenol A in complex samples by in-column molecularly imprinted solid-phase extraction coupled with capillary electrophoresis, Microchem. J. 121 (2015) $1-5$.

[56] L. Mariño-Repizo, F. Kero, V. Vandell, A. Senior, M. Isabel Sanz-Ferramola, S. Cerutti, et al., A novel solid phase extraction - ultra high performance liquid chromatography-tandem mass spectrometry method for the quantification of ochratoxin A in red wines, Food Chem. 172 (2015) 663-668.

[57] M. Havelcová, I. Sýkorová, K. Mach, Z. Dvořák, Organic geochemistry of fossil resins from the Czech Republic, Procedia Earth Planet. Sci. 10 (2014) 303-312.

[58] B. Allard, S. Derenne, Characterization of soil organic matter using microwave assisted acid and base hydrolysis, Org. Geochem. 65 (2013) 103-117.

[59] L. Han, K. Sun, J. Jin, B. Xing, Some concepts of soil organic carbon characteristics and mineral interaction from a review of literature, Soil Biol. Biochem. 94 (2016) 107-121.

[60] L.H. Lin, M.J. Simpson, Enhanced extractability of cutin- and suberin-derived organic matter with demineralization implies physical protection over chemical recalcitrance in soil, Org. Geochem. 97 (2016) 111-121.

[61] M. Gao, Z. Yang, Y. Wang, Y. Bai, F. Li, K. Xie, Impact of calcium on the synergistic effect for the reactivity of coal char gasification in $\mathrm{H} 2 \mathrm{O} / \mathrm{CO} 2$ mixtures, Fuel 189 (2017) 312-321.

[62] R. Spaccini, X.Y. Song V. Cozzolino, A. Piccolo, Molecular evaluation of soil organic matter characteristics in three agricultural soils by improved off-line thermochemolysis: the effect of hydrofluoric acid demineralisation treatment, Anal. Chim. Acta 802 (2013) 46-55.

[63] L. Decq, F. Lynen, M. Schilling, W. Fremout, V. Cattersel, D. Steyaert, et al., The analysis of European lacquer: optimization of thermochemolysis temperature of natural resins, Appl. Phys. Mater. Sci. Process 122 (2016) 1-8.

[64] S.S. Choi, J.E. Ko, Dimerization reactions of amino acids by pyrolysis, J. Anal. Appl. Pyrolysis 89 (2010) 74-86.

[65] A. Venema, R.C.A. Boom-Van Geest, In-situ hydrolysis/methylation pyrolysis CGC for the characterization of polyaramides, J. Microcolumn Sep. 7 (1995) 337-343.

[66] W. Montgomery, E.A. Jaramillo, S.H. Royle, S.P. Kounaves, Di SchulzeMakuch, M.A. Sephton, Effects of oxygen-containing salts on the detection of organic biomarkers on Mars and in terrestrial analog soils, Astrobiology 19 (2019) 711-721. 
[67] K. Oba, H. Ohtani, S. Tsuge, Confirmation of the xanthone structure in thermally treated polycarbonates by reactive pyrolysis-gas chromatography/ mass spectrometry, Polym. Degrad. Stabil. 74 (2001) 171-176.

[68] D. Fabbri, V. Baravelli, G. Chiavari, S. Prati, Profiling fatty acids in vegetable oils by reactive pyrolysis - gas chromatography with dimethyl carbonate and titanium silicate, J. Chromatogr., A 1100 (2005) 218-222.

[69] L. Wang, Y. Ishida, H. Ohtani, S. Tsuge, Characterization of natural resin shellac by reactive pyrolysis - gas chromatography in the presence of organic alkali, Anal. Chem. 71 (1999) 1316-1322.

[70] J.M. van Mourik, K.G.J. Nierop, D.A.G. Vandenberghe, Radiocarbon and optically stimulated luminescence dating based chronology of a polycyclic driftsand sequence at Weerterbergen (SE Netherlands), Catena 80 (2010) $170-181$.

[71] C.E. Stewart, Evaluation of angiosperm and fern contributions to soil organic matter using two methods of pyrolysis-gas chromatography-mass spectrometry, Plant Soil 351 (2012) 31-46.

[72] J. Templier, F. Miserque, N. Barré, F. Mercier, J.P. Croué, S. Derenne, Is nitrogen functionality responsible for contrasted responses of riverine dissolved organic matter in pyrolysis? J. Anal. Appl. Pyrolysis 97 (2012) 62-72.

[73] A. Vidal, K. Quenea, M. Alexis, S. Derenne, Molecular fate of root and shoot litter on incorporation and decomposition in earthworm casts, Org. Geochem. 101 (2016) 1-10.

[74] P. Barré, K. Quénéa, A. Vidal, L. Cécillon, B.T. Christensen, T. Kätterer, et al. Microbial and plant-derived compounds both contribute to persistent soil organic carbon in temperate soils, Biogeochemistry 140 (2018) 81-92.

[75] J. Campo, R.J. Stijsiger, E. Nadal-Romero, E.L.H. Cammeraat, The effects of land abandonment and long-term afforestation practices on the organic carbon stock and lignin content of Mediterranean humid mountain soils, Eur. J. Soil Sci. 70 (2019) 947-959.

[76] M. Fischer, B.M. Scholz-Böttcher, Simultaneous trace identification and quantification of common types of microplastics in environmental samples by pyrolysis-gas chromatography-mass spectrometry, Environ. Sci. Technol. 51 (2017) 5052-5060.

[77] F. Ohira, M. Yamamoto, K. Takemura, A. Hayashida, Response of vegetation in central Japan to precession during the last 147,000 years: a lignin record from Lake Biwa core BIW08-B, Quat. Int. 349 (2014) 59-67.

[78] S.K. Dodla, J.J. Wang, R.L. Cook, Molecular composition of humic acids from coastal wetland soils along a salinity gradient, Soil Sci. Soc. Am. J. 76 (2012) 1592-1605.

[79] C. Ferro-Vázquez, J. Kaal, F.J. Santos Arévalo, F. Criado Boado, Molecular fingerprinting of $14 \mathrm{C}$ dated soil organic matter fractions from archaeological settings in NW Spain, Radiocarbon 61 (2019) 101-130.

[80] R.N.T.M. Kabuyah, B.E. van Dongen, A.D. Bewsher, C.H. Robinson, Decomposition of lignin in wheat straw in a sand-dune grassland, Soil Biol. Biochem. 45 (2012) 128-131.

[81] G.D. Abbott, E.Y. Swain, A.B. Muhammad, K. Allton, L.R. Belyea, C.G. Laing, et al., Effect of water-table fluctuations on the degradation of Sphagnum phenols in surficial peats, Geochem. Cosmochim. Acta 106 (2013) 177-191.

[82] L. Jeanneau, A. Jaffrezic, A.-C. Pierson-Wickmann, G. Gruau, T. Lambert, P. Petitjean, Constraints on the sources and production mechanisms of dissolved organic matter in soils from molecular biomarkers, Vadose Zone J. 13 (2014).

[83] H. Guénet, E. Demangeat, M. Davranche, D. Vantelon, A.C. Pierson-Wickmann, E. Jardé, et al., Experimental evidence of REE size fraction redistribution during redox variation in wetland soil, Sci. Total Environ. 631-632 (2018) 580-588.

[84] N. Fujisawa, M. Fukushima, M. Yamamoto, H. Iwai, T. Komai, Y. Kawabe, et al., Structural alterations of humic acid fractions in a steel slag-compost fertilizer during fertilization. Analysis by pyrolysis/methylation-gas chromatography/ mass spectrometry, J. Anal. Appl. Pyrolysis 95 (2012) 126-133.

[85] R. Okabe, A. Miura, M. Fukushima, M. Terashima, M. Sasaki, S. Fukuchi, et al., Characterization of an adsorbed humin-like substance on an allophanic soil formed via catalytic polycondensation between catechol and glycine, and its adsorption capability to pentachlorophenol, Chemosphere 83 (2011) $1502-1506$.

[86] K. Nagasawa, B. Wang, K. Nishiya, K. Ushijima, Q. Zhu, M. Fukushima, et al., Effects of humic acids derived from lignite and cattle manure on antioxidant enzymatic activities of barley root, J. Environ. Sci. Health Part B Pestic. Food Contam. Agric. Wastes 51 (2016) 81-89.

[87] M. Fukushima, M. Yamamoto, T. Komai, K. Yamamoto, Studies of structural alterations of humic acids from conifer bark residue during composting by pyrolysis-gas chromatography/mass spectrometry using tetramethylammonium hydroxide (TMAH-py-GC/MS), J. Anal. Appl. Pyrolysis 86 (2009) 200-206

[88] L. Grasset, P. Rovira, A. Amblès, TMAH-preparative thermochemolysis for the characterization of organic matter in densimetric fractions of a Mediterranean forest soil, J. Anal. Appl. Pyrolysis 85 (2009) 435-441.

[89] R. Spaccini, P. Mazzei, A. Squartini, M. Giannattasio, A. Piccolo, Molecular properties of a fermented manure preparation used as field spray in biodynamic agriculture, Environ. Sci. Pollut. Res. 19 (2012) 4214-4225.

[90] D. Martinez-Balmori, R. Spaccini, N.O. Aguiar, E.H. Novotny, F.L. Olivares, L.P. Canellas, Molecular characteristics of humic acids isolated from vermicomposts and their relationship to bioactivity, J. Agric. Food Chem. 62 (2014) 11412-11419.
[91] D. Martinez-Balmori, F.L. Olivares, R. Spaccini, K.P. Aguiar, M.F. Araújo, N.O. Aguiar, et al., Molecular characteristics of vermicompost and their relationship to preservation of inoculated nitrogen-fixing bacteria, J. Anal. Appl. Pyrolysis 104 (2013) 540-550.

[92] A. Spaldonová, J. Frouz, The role of Armadillidium vulgare (Isopoda: oniscidea) in litter decomposition and soil organic matter stabilization, Appl. Soil Ecol. 83 (2014) 186-192.

[93] J. Frouz, T. Cajthaml, O. Mudrák, The effect of lignin photodegradation on decomposability of Calamagrostis epigeios grass litter, Biodegradation 22 (2011) 1247-1254.

[94] J.A. Siles, T. Cajthaml, A. Filipová, S. Minerbi, R. Margesin, Altitudinal, seasonal and interannual shifts in microbial communities and chemical composition of soil organic matter in Alpine forest soils, Soil Biol. Biochem. 112 (2017) 1-13.

[95] Š. Angst, T. Cajthaml, G. Angst, H. Šimáčková, J. Brus, J. Frouz, Retention of dead standing plant biomass (marcescence) increases subsequent litter decomposition in the soil organic layer, Plant Soil 418 (2017) $571-579$.

[96] E.Y. Swain, G.D. Abbott, The effect of redox conditions on sphagnum acid thermochemolysis product distributions in a northern peatland, J. Anal. Appl, Pyrolysis 103 (2013) 2-7.

[97] P. Zhou, G.X. Pan, R. Spaccini, A. Piccolob, Molecular changes in particulate organic matter ( POM ) in a typical Chinese paddy soil under different longterm fertilizer treatments, Eur. J. Soil Sci. 61 (2010) 231-242.

[98] A. Nebbioso, A. Piccolo, Advances in humeomics: enhanced structural identification of humic molecules after size fractionation of a soil humic acid, Anal. Chim. Acta 720 (2012) 77-90.

[99] G. Pascaud, M. Soubrand, L. Lemee, J. Laduranty, A. El-Mufleh, M. Rabiet, et al., Molecular fingerprint of soil organic matter as an indicator of pedogenesis processes in Technosols, J. Soils Sediments 17 (2017) 340-351.

[100] A. Sawicka, A. Burnstock, F.C. Izzo, K. Keune, J.J. Boon, K. Kirsch, et al., An investigation into the viability of removal of lead soap efflorescence from contemporary oil paintings, in: Issues Contemp. Oil Paint, 2014 pp. 311-332.

[101] H.E. Barden, U. Bergmann, N.P. Edwards, V.M. Egerton, P.L. Manning, S. Perry et al., Bacteria or melanosomes? A geochemical analysis of micro-bodies on a tadpole from the Oligocene Enspel Formation of Germany, Palaeobiodivers. Palaeoenviron. 95 (2015) 33-45.

[102] M. Fukushima, X. Tu, A. Aneksampant, A. Tanaka, Analysis of branched-chain fatty acids in humic substances as indices for compost maturity by pyrolysis-gas chromatography/mass spectrometry with tetramethylammonium hydroxide (TMAH-py-GC/MS), J. Mater. Cycles Waste Manag. 20 (2018) 176-184.

[103] D. Rocker, V. Kisand, B. Scholz-Böttcher, T. Kneib, A. Lemke, J. Rullkötter, et al., Differential decomposition of humic acids by marine and estuarine bacterial communities at varying salinities, Biogeochemistry 111 (2012) $331-346$.

[104] X. Fan, J. Song, Comparative study for separation of atmospheric humic-like substance ( HULIS ) by ENVI-18, HLB , XAD-8 and DEAE sorbents : elemental composition, FT-IR , $1 \mathrm{H}$ NMR and off-line thermochemolysis with tetramethylammonium hydroxide ( TMAH ), Chemosphere 93 (2013) $1710-1719$.

[105] A.M. Tadini, I.C. Constantino, A. Nuzzo, R. Spaccini, A. Piccolo, A.B. Moreira, et al., Characterization of typical aquatic humic substances in areas of sugarcane cultivation in Brazil using tetramethylammonium hydroxide thermochemolysis, Sci. Total Environ. 518-519 (2015) 201-208.

[106] X. Fan, S. Wei, M. Zhu, J. Song, P. Peng, Molecular characterization of primary humic-like substances in fine smoke particles by thermochemolysis-gas chromatography-mass spectrometry, Atmos. Environ. 180 (2018) 1-10.

[107] S. Farzadnia, R.D. Nimmagadda, C. McRae, A comparative structural study of nitrogen-rich fulvic acids from various Antarctic lakes, Environ. Chem. 14 (2017) 502-514.

[108] M. Gomes, M. Martins, S. Leath, K. Stelwagen, Direct analysis of fatty acid profile from milk by thermochemolysis - gas chromatography - mass spectrometry, J. Chromatogr., A 1218 (2011) 316-323.

[109] Z. Steinmetz, M.P. Kurtz, J.P. Zubrod, A.H. Meyer, M. Elsner, G.E. Schaumann, Biodegradation and photooxidation of phenolic compounds in soil-a compound-specific stable isotope approach, Chemosphere 230 (2019) $210-218$.

[110] S.-S. Choi, J. Ko, Analysis of cyclic pyrolysis products formed from amino acid monomer, J. Chromatogr., A 1218 (2011) 8443-8455.

[111] F. Benlboukht, L. Lemee, S. Amir, A. Ambles, M. Hafidi, Biotransformation of organic matter during composting of solid wastes from traditional tanneries by thermochemolysis coupled with gas chromatography and mass spectrometry, Ecol. Eng. 90 (2016) 87-95.

[112] P. kaur, C. Balomajumder, Simultaneous biodegradation of mixture of carbamates by newly isolated Ascochyta sp. CBS 237.37, Ecotoxicol, Environ. Saf. 169 (2019) 590-599.

[113] J. Waissman, M. Honig, S. Pecker, A. Benyamini, A. Hamo, S. Ilani, Realization of pristine and locally tunable one-dimensional electron systems in carbon nanotubes, Nat. Nanotechnol. 8 (2013) 569-574.

[114] R.S. Patkar, M.G. Seelan, V. Ramgopal Rao, A highly sensitive piezoresistive cantilever based sensor platform for detection of macronutrients in soil, IEEE-NANO 2015 - 15th Int. Conf. Nanotechnol. (2015) 751-754. 
[115] M. Xu, T. Bearda, H.S. Radhakrishnan, M. Filipič, I. Gordon, M. Debucquoy, et al., Laser assisted patterning of a-Si:H: detailed investigation of laser damage, Phys. Status Solidi Rapid Res. Lett. 11 (2017) 1-5.

[116] J. Patočka, A. Krejčová, K. Stojarová, K. Hrdá, M. Pouzar, The ICP-OES method for determination of zinc in Enchytraeus crypticus and agarose gel from ecotoxicological tests, Chem. Pap. 73 (2019) 159-164.

[117] G. Karavalakis, G. Anastopoulos, D. Karonis, S. Stournas, Biodiesel production using tetramethyl- and benzyltrimethyl ammonium hydroxides as strong base catalysts, Fuel Process, Technol. 91 (2010) 1585-1590.

[118] E. Kaschak, B. Knopf, J.H. Petersen, N.H. Bings, H. König, Biotic methylation of mercury by intestinal and sulfate-reducing bacteria and their potential role in mercury accumulation in the tissue of the soil-living Eisenia foetida, Soil Biol. Biochem. 69 (2014) 202-211.

[119] Z. Huang, X.D. Pan, J.L. Han, P.G. Wu, J. Tang, Y. Tan, Determination of methylmercury in marine fish from coastal areas of Zhejiang, China, Food Addit. Contam. Part B Surveill. 5 (2012) 182-187.

[120] D. Grotto, J. Vicentini, J.P. Friedmann Angeli, E. Francisco Latorraca, P.A. Pontes Monteiro, G.R. Mazzaron Barcelos, et al., Evaluation of protective effects of fish oil against oxidative damage in rats exposed to methylmercury, Ecotoxicol. Environ. Saf. 74 (2011) 487-493.

[121] C. Feng, Z. Pedrero, P. Li, B. Du, X. Feng, M. Monperrus, et al., Investigation of $\mathrm{Hg}$ uptake and transport between paddy soil and rice seeds combining $\mathrm{Hg}$ isotopic composition and speciation, Elem. Sci. Anthr. 4 (2016), 000087.

[122] H.D.C. Viégas, J.M.S. Almeida, C.A. Lacerda, J.B. Silva, A.L.B. Marques, E.P. Marques, A rapid and sensitive voltammetric determination of sulphur in biodiesel in samples no treated and treated with TMAH, Fuel 202 (2017) 464-469.

[123] A. Iveković, G. Dražić, S. Novak, Densification of a SiC-matrix by electrophoretic deposition and polymer infiltration and pyrolysis process, J. Eur Ceram. Soc. 31 (2011) 833-840.

[124] R. Mayén-Mondragõn, G. Falk, R. Clasen, Electrophoretic impregnation/ deposition complemented with polymeric templating for the fabrication of functionalized-porosity layered-ceramics: a Solid-oxide-fuel-cells approach, J. Am. Ceram. Soc. 95 (2012) 593-599.

[125] Z. Li, B. Wang, S. Ge, L. Yan, Y. Liu, Z. Li, et al., A simultaneous analysis method of polycyclic aromatic hydrocarbons, nicotine, cotinine and metals in human hair, Environ. Pollut. 219 (2016) 66-71.

[126] A.M. Nunes, T.S. Acunha, E.Q. Oreste, F.G. Lepri, M.A. Vieira, A.J. Curtius, et al., Determination of $\mathrm{Ca}, \mathrm{Cu}, \mathrm{Fe}$ and $\mathrm{Mg}$ in fresh and processed meat treated with tetramethylammonium hydroxide by atomic absorption spectrometry, J. Braz. Chem. Soc. 22 (2011) 1850-1857.

[127] H.E. Bowley, S.D. Young, E.L. Ander, N.M.J. Crout, M.J. Watts, E.H. Bailey, Iodine bioavailability in acidic soils of Northern Ireland, Geoderma 348 (2019) 97-106.

[128] H. Fujiwara, Observation of radioactive iodine (131I,129I) in cropland soil after the Fukushima nuclear accident, Sci. Total Environ. 566-567 (2016) 1432-1439.

[129] V.C. Costa, R.M. Pereira, J.E. Mello, J.R. Brum, R.S. Picoloto, M.F. Mesko, Indirect determination of chlorine and fluorine in eye shadow by ion chromatography after an eco-friendly sample preparation method based on combustion reaction, Microchem. J. 150 (2019) 104125.

[130] A. Osswald, A. Poszwa, M. Bueno, C. Arnaudguilhem, D. Billet, Y. Thiry, et al., Contribution of microbial activity to formation of organically bound chlorine during batch incubation of forest soil using $37 \mathrm{Cl}$ as a tracer, Soil Biol. Biochem. 100 (2016) 210-217.

[131] S.C. Sheppard, J.M. Long, B. Sanipelli, Plant/soil concentration ratios for paired field and garden crops, with emphasis on iodine and the role of soil adhesion, J. Environ. Radioact. 101 (2010) 1032-1037.

[132] I. Shtangeeva, P. Perämäki, M. Niemelä, E. Kurashov, Y. Krylova, Potential of wheat (Triticum aestivum L.) and pea (Pisum sativum) for remediation of soils contaminated with bromides and PAHs, Int. J. Phytoremediation 20 (2018) 560-566.

[133] I. Shtangeeva, M. Niemelä, P. Perämäki, A. Ryumin, S. Timofeev, S. Chukov, et al., Phytoextration of bromine from contaminated soil, J. Geochem. Explor 174 (2017) 21-28.

[134] N. Yamaguchi, M. Nakano, R. Takamatsu, H. Tanida, Inorganic iodine incorporation into soil organic matter: evidence from iodine K-edge X-ray absorption near-edge structure, J. Environ. Radioact. 101 (2010) 451-457.

[135] E. Duborská, M. Urík, M. Bujdoš, J. Kubová, Aging and substrate type effects on iodide and iodate accumulation by barley (hordeum vulgare L.), water. Air, Soil Pollut 227 (2016) 407

[136] E. Duborská, M. Urík, J. Kubová, Interaction with soil enhances the toxic effect of iodide and iodate on barley (Hordeum vulgare L.) compared to artificial culture media during initial growth stage, Arch. Agron Soil Sci. 64 (2018) 46-57.

[137] E. Duborská, M. Urík, M. Bujdoš, M. Matulová, Influence of physicochemica properties of various soil types on iodide and iodate sorption, Chemosphere 214 (2019) 168-175.

[138] K. Tagami, S. Uchida, A. Takeda, S. Yamasaki, Estimation of plant-unavailable iodine concentrations in agricultural fields, Soil Sci. Soc. Am. J. 74 (2010) 1562-1567.

[139] S. Smoleń, W. Sady, Influence of iodine fertilization and soil application of sucrose on the effectiveness of iodine biofortification, yield, nitrogen metabolism and biological quality of spinach, Acta Sci. Pol. Hortorum Cultus. 10 (2011) 51-63.
[140] D. Mani, S.S. Kumar, M.A. Rasheed, D.J. Patil, A.M. Dayal, G.G. Rao, et al., Soil iodine determination in deccan syneclise, India: implications for near surface geochemical hydrocarbon prospecting, Nat. Resour. Res. 20 (2011) 75-88.

[141] D.B. Kumssa, E.J.M. Joy, S.D. Young, D.W. Odee, E.L. Ander, M.R. Broadley, Variation in the mineral element concentration of Moringa oleifera Lam. and M. stenopetala (Bak. f.) Cuf.: role in human nutrition, PloS One 12 (2017) $1-26$.

[142] M. Roulier, M. Bueno, Y. Thiry, F. Coppin, P.O. Redon, I. Le Hécho, et al., Iodine distribution and cycling in a beech (Fagus sylvatica) temperate forest, Sci. Total Environ. 645 (2018) 431-440.

[143] S. Smoleń, I. Ledwożyw-Smoleń, W. Sady, Iodine biofortification of spinach by soil fertigation with additional application of humic and fulvic acids, N. Z. J. Crop Hortic. Sci. 45 (2017) 233-250.

[144] M. Roulier, F. Coppin, M. Bueno, M. Nicolas, Y. Thiry, C. Della Vedova, et al., Iodine budget in forest soils: influence of environmental conditions and soil physicochemical properties, Chemosphere 224 (2019) 20-28.

[145] S. Uchida, K. Tagami, Iodine transfer from agricultural soils to edible part of crops, Proc. Radiochem. 1 (2011) 279-283.

[146] S. Smolen, L. Skoczylas, I. Ledwozyw-Smolen, R. Rakoczy, A. Kopec, E. Piktkowska, et al., Iodine and selienium biofortification of lectuce (Lactuca sativa L.) by soil fertilization with various compounds of these elements, Acta Sci. Pol. Cultus. 15 (2016) 69-91.

[147] S. Chung, A. Chan, Y. Xiao, V. Lin, Y.Y. Ho, Iodine content in commonly consumed food in Hong Kong and its changes due to cooking, Food Addit. Contam. Part B Surveill. 6 (2013) 24-29.

[148] I. Cakmak, C. Prom-u-thai, L.R.G. Guilherme, A. Rashid, K.H. Hora, A. Yazici, et al., Iodine biofortification of wheat, rice and maize through fertilizer strategy, Plant Soil 418 (2017) 319-335.

[149] A. Daraoui, R. Michel, M. Gorny, D. Jakob, R. Sachse, H.A. Synal, et al., Iodine129, iodine-127 and caesium-137 in the environment: soils from Germany and Chile, J. Environ. Radioact. 112 (2012) 8-22.

[150] J.E. Olson, M.L. Adamic, D.C. Snyder, J.L. Brookhart, P.A. Hahn, M.G. Watrous, Independent measurements of 129I content in environmental reference materials using accelerator and thermal ionization mass spectrometry, Nucl. Instrum. Methods Phys. Res. Sect. B Beam Interact. Mater. Atoms 438 (2019) 84-88.

[151] M.J. Watts, J. O'Reilly, A. Maricelli, A. Coleman, E.L. Ander, N.I. Ward, A snapshot of environmental iodine and selenium in La Pampa and San Juan provinces of Argentina, J. Geochem. Explor. 107 (2010) 87-93.

[152] G. Yang. J. Hu, H. Tsukada, H. Tazoe, Y. Shao, M. Yamada, Vertical distribution of 129 I and radiocesium in forest soil collected near the Fukushima Daiichi Nuclear Power Plant boundary, Environ. Pollut. 250 (2019) 578-585.

[153] T.H. Hu, L.M. Whang, P.W.G. Liu, Y.C. Hung, H.W. Chen, L. Bin Lin, et al. Biological treatment of TMAH (tetra-methyl ammonium hydroxide) in a fullscale TFT-LCD wastewater treatment plant, Bioresour. Technol. 113 (2012) 303-310.

[154] T. Danshita, Y. Miyaoka, N. Matsuura, H. Sumino, T. Yamaguchi, K. Syutsubo, Influence of tetramethylammonium hydroxide (TMAH) on the microbial properties of anaerobic granular sludge acclimated to isoplophyl alcohol (IPA) wastewater under psychrophilic conditions, J. Environ. Sci. Heal. - Part A Toxic/Hazardous Subst. Environ. Eng. 53 (2018) 1015-1021.

[155] L.M. Whang, T.H. Hu, P.W.G. Liu, Y.C. Hung, T. Fukushima, Y.J. Wu, et al., Molecular analysis of methanogens involved in methanogenic degradation of tetramethylammonium hydroxide in full-scale bioreactors, Appl. Microbiol. Biotechnol. 99 (2015) 1485-1497.

[156] A. Duval, M. Lawoko, A review on lignin-based polymeric, micro- and nanostructured materials, React. Funct. Polym. 85 (2014) 78-96.

[157] P. Azadi, O.R. Inderwildi, R. Farnood, D.A. King, Liquid fuels, hydrogen and chemicals from lignin: a critical review, Renew. Sustain. Energy Rev. 21 (2013) 506-523.

[158] J.C. Del Río, P. Prinsen, J. Rencoret, L. Nieto, J. Jiménez-Barbero, J. Ralph, et al. Structural characterization of the lignin in the cortex and pith of elephant grass (Pennisetum purpureum) stems, J. Agric. Food Chem. 60 (2012) 3619-3634.

[159] D.C. Waggoner, Lignin contribution to the global carbon pool : Investigating the abiotic modification of lignin by reactive oxygen species, Old Dominion University, 2017.

[160] A. Brandt, L. Chen, B.E. Van Dongen, T. Welton, J.P. Hallett, Structural changes in lignins isolated using an acidic ionic liquid water mixture, Green Chem. 17 (2015) 5019-5034.

[161] J.S. Schilling, J. Ai, R.A. Blanchette, S.M. Duncan, T.R. Filley, U.W. Tschirner, Lignocellulose modifications by brown rot fungi and their effects, as pretreatments, on cellulolysis, Bioresour. Technol. 116 (2012) 147-154.

[162] J.A. Ceja-Navarro, U. Karaoz, M. Bill, Z. Hao, R.A. White, A. Arellano, et al., Gut anatomical properties and microbial functional assembly promote lignocellulose deconstruction and colony subsistence of a wood-feeding beetle, Nat. Microbiol. 4 (2019) 864-875.

[163] J. Ke, D.D. Laskar, D. Singh, S. Chen, In situ lignocellulosic unlocking mechanism for carbohydrate hydrolysis in termites : crucial lignin modification, Biotechnol. Biofuels 4 (2011) 17.

[164] J. Kaal, O. Serrano, K.G.J. Nierop, J. Schellekens, A. Martínez Cortizas, M.A. Mateo, Molecular composition of plant parts and sediment organic matter in a Mediterranean seagrass (Posidonia oceanica) mat, Aquat. Bot. 133 (2016) 50-61. 
[165] J. Kaal, O. Serrano, A. Martínez Cortizas, J.A. Baldock, P.S. Lavery, Millennialscale changes in the molecular composition of Posidonia australis seagrass deposits: implications for Blue Carbon sequestration, Org. Geochem. 137 (2019) 103898.

[166] A.V. Marques, J. Rencoret, A. Gutiérrez, J.C. Del Río, H. Pereira, Ferulates and lignin structural composition in cork, Holzforschung 70 (2016) 275-289.

[167] L. Lemée, D. Kpogbemabou, L. Pinard, R. Beauchet, J. Laduranty, Biological pretreatment for production of lignocellulosic biofuel, Bioresour. Technol. 117 (2012) 234-241.

[168] J. Kaal, O. Serrano, C. José, J. Rencoret, Radically different lignin composition in Posidonia species may link to differences in organic carbon sequestration capacity, Org. Geochem. 124 (2018) 247-256.

[169] T. Klotzbücher, K. Kaiser, T.R. Filley, K. Kalbitz, Processes controlling the production of aromatic water-soluble organic matter during litter decomposition, Soil Biol. Biochem. 67 (2013) 133-139.

[170] P.J. Hatton, S. Chatterjee, T.R. Filley, K. Dastmalchi, A.F. Plante, S. Abiven, et al., Tree taxa and pyrolysis temperature interact to control the efficacy of pyrogenic organic matter formation, Biogeochemistry 130 (2016) 103-116.

[171] J.S. Watson, W.T. Fraser, M.A. Sephton, Formation of a polyalkyl macromolecule from the hydrolysable component within sporopollenin during heating/pyrolysis experiments with Lycopodium spores, J. Anal. Appl. Pyrolysis 95 (2012) 138-144.

[172] H. Lu, W. Wu, Y. Chen, H. Wang, M. Devare, J.E. Thies, Soil microbial community responses to Bt transgenic rice residue decomposition in a paddy field, J. Soils Sediments 10 (2010) 1598-1605.

[173] G.J.M. Versteegh, P. Blokker, K.A. Bogus, I.C. Harding, J. Lewis, S. Oltmanns, et al., Infra red spectroscopy , flash pyrolysis, thermally assisted hydrolysis and methylation ( THM ) in the presence of tetramethylammonium hydroxide ( TMAH ) of cultured and sediment-derived Lingulodinium polyedrum ( Dinoflagellata ) cys, Org. Geochem. 43 (2012) 92-102.

[174] A.J. Blyth, J.S. Watson, J. Woodhead, J. Hellstrom, Organic compounds preserved in a 2.9 million year old stalagmite from the Nullarbor Plain, Australia, Chem. Geol. 279 (2010) 101-105.

[175] K.G.J. Nierop, E.N. Speelman, J.W. de Leeuw, G.J. Reichart, The omnipresent water fern Azolla caroliniana does not contain lignin, Org. Geochem. 42 (2011) 846-850.

[176] U. Wongsiriwan, Y. Noda, C. Song, P. Prasassarakich, Y. Yeboah, Lignocellulosic biomass conversion by sequential combination of organic acid and base treatments, Energy Fuels 24 (2010) 3232-3238.

[177] R.A. Smith, E. Gonzales-Vigil, S.D. Karlen, J.-Y. Park, F. Lu, C. Wilkerson, et al., Engineering monolignol p-coumarate conjugates into Poplar and Arabidopsis lignins, Plant Physiol. 169 (2015) 2992-3001.

[178] G.D. Abbott, A. Muhammad, L. Belyea, C. Laing, G.L. Cowie, The biogeochemistry of Sphagnum mosses - the effects of substrate source on their phenolic composition, in: 19th World Congr. Soil Sci. Soil Solut. A Chang. World, Brisbane, Australia, 2010, pp. 195-197.

[179] A.M. Baetsen-Young, J.E. Kaminski, M. Tien, Lignocellulose degrading capabilities of in creeping bentgrass, Int. Turfgrass Soc. Res. J. 13 (2017) 145-152.

[180] J. Ke, D.D. Laskar, S. Chen, Tetramethylammonium hydroxide (TMAH) thermochemolysis for probing in situ softwood lignin modification in each gut segment of the termite, J. Agric. Food Chem. 61 (2013) 1299-1308.

[181] T. Ohra-Aho, P. Niemi, A.M. Aura, M. Orlandi, K. Poutanen, J. Buchert, et al., Structure of brewer's spent grain lignin and its interactions with gut microbiota in vitro, J. Agric. Food Chem. 64 (2016) 812-820.

[182] Q. Chen, M.N. Marshall, S.M. Geib, M. Tien, T.L. Richard, Effects of laccase on lignin depolymerization and enzymatic hydrolysis of ensiled corn stover, Bioresour. Technol. 117 (2012) 186-192.

[183] M. Olivella, C. Bazzicalupi, A. Bianchi, J.C. del Río, N. Fiol, I. Villaescusa, Binding interactions between suberin monomer components and pesticides, Sci. Total Environ. 527-528 (2015) 159-164.

[184] J.W. Turner, B.E. Hartman, P.G. Hatcher, Structural characterization of suberan isolated from river birch (Betula nigra) bark, Org. Geochem. 57 (2013) 41-53.

[185] M. Angels Olivella, J.C. del Rio, Suberin composition from different bark layers of Quercus suber L. by Py-GC/MS in the presence of tetramethylammonium Hydroxide (TMAH), Bioresources 6 (2011) 4936-4941.

[186] M.W. Haenel, Recent progress in coal structure research, Fuel 71 (1992) $1211-1223$.

[187] Y. He, L. Yan, Y. Liu, Y. Liu, Y. Bai, J. Wang, et al., Effect of SiO2/Al2O3 ratios of HZSM-5 zeolites on the formation of light aromatics during lignite pyrolysis, Fuel Process. Technol. 188 (2019) 70-78.

[188] L. Yan, Y. Bai, Y. Liu, Y. He, F. Li, Effects of low molecular compounds in coal on the catalytic upgrading of gaseous tar, Fuel 226 (2018) 316-321.

[189] M. Radke, R.G. Schaefer, D. Leythaeuser, M. Teichmüller, Composition of soluble organic matter in coals: relation to rank and liptinite fluorescence, Geochem. Cosmochim. Acta 44 (1980) 1787-1800.

[190] J. Kong, X.Y. Wei, M.X. Zhao, Z.K. Li, H.L. Yan, Q.X. Zheng, et al., Effects of sequential extraction and thermal dissolution on the structure and composition of Buliangou subbituminous coal, Fuel Process. Technol. 148 (2016) $324-331$.

[191] C. Xia, T. Wiltowski, S. Harpalani, Y. Liang, Coal depolymerization using permanganate under optimal conditions, Int. J. Coal Geol. 168 (2016) 214-221.

[192] L. Grasset, Z. Vlčková, J. Kučerík, A. Amblès, A. Grasset, Z. Vlčková, J. Kučerík, L. Amblès, Characterization of lignin monomers in low rank coal humic acids using the derivatization/reductive cleavage method, Org. Geochem. 41 (2010) 905-909.

[193] S. Nasir, T.B. Sarfaraz, T.V. Verheyen, A.L. Chaffee, Structural elucidation of humic acids extracted from Pakistani lignite using spectroscopic and thermal degradative techniques, Fuel Process. Technol. 92 (2011) 983-991.

[194] J.H. Shinn, From coal to single-stage and two-stage products: a reactive model of coal structure, Fuel 63 (1984) 1187-1196.

[195] M. Stefanova, Molecular indicators of the Oligocene Bobov Dol coal organic matter composition from bitumen analysis and preparative off-line thermochemolysis, Int. J. Coal Geol. 118 (2013) 1-7.

[196] J. Kaal, W.H. Abdullah, Y. Makeen, K.A. Mustapha, L. Asiwaju, S.G. Sia, et al., Effects of maturity on the pyrolytic fingerprint of coals from North Borneo, Int. J. Coal Geol. 182 (2017) 1-13.

[197] E.E. Igbinigie, C.C.Z. Mutambanengwe, P.D. Rose, Phyto-bioconversion of hard coal in the Cynodon dactylon/coal rhizosphere, Biotechnol. J. 5 (2010) 292-303.

[198] X.M. Ma, R. Lu, T. Miyakoshi, Application of pyrolysis gas chromatography/ mass spectrometry in lacquer research: a review, Polymers 6 (2014) $132-144$.

[199] H. van Keulen, M. Schilling, AMDIS, EXCEL, A powerful combination for evaluating THM-Py-GC/MS results from European lacquers, Stud. Conserv. 64 (2019) S74-S80.

[200] A. Heginbotham, J. Chang, H. Khanjian, M.R. Schilling, Some observations on the composition of Chinese lacquer, Stud. Conserv. 61 (2016) 28-37.

[201] R. Takei, R. Lu, T. Miyakoshi, Dimer structures and laccase-catalyzed polymerization mechanism of laccol in fresh rhus succedanea lacquer sap, Int. J. Polym. Anal. Char. 18 (2013) 199-210.

[202] R. Oshima, Y. Yamauchi, C. Watanabe, J. Kumanotani, Enzymic oxidative coupling of urushiol in sap of the lac tree, Rhus vernicifera, J. Org. Chem. 50 (1985) 2613-2621.

[203] F. Modugno, F. Di Gianvincenzo, I. Degano, I.D. van der Werf, I. Bonaduce K.J. van den Berg, On the influence of relative humidity on the oxidation and hydrolysis of fresh and aged oil paints, Sci. Rep. 9 (2019) 5533.

[204] N. Niimura, T. Miyakoshi, Structural study of oriental lacquer films during the hardening process, Talanta 70 (2006) 146-152.

[205] M.J. Petisca, C.R. Matsen, Lisbon as seen from China: conundrums posed by a set of lacquered nesting tables, Stud. Conserv. 64 (2019) S91. -S100.

[206] O. Katsibiri, R.F. Howe, Characterisation of the transparent surface coatings on post-Byzantine icons using microscopic, mass spectrometric and spectroscopic techniques, Microchem. J. 94 (2010) 14-23.

[207] S.Q. Fang, H. Zhang, B.J. Zhang, Y. Zheng, The identification of organic additives in traditional lime mortar, J. Cult. Herit. 15 (2014) 144-150.

[208] J. Kumanotani, Urushi (oriental lacquer) - a natural aesthetic durable and future-promising coating, Prog. Org. Coating 26 (1995) 163-195.

[209] Jessica Burkhart Chasen, The Treatment and Technical Study of Chinese Export Lacquer at the Winterthur Museum,garden \& library, Winterthur/ University of Delaware program in art conservation, 2016.

[210] X. Hao, M.R. Schilling, X. Wang, H. Khanjian, A. Heginbotham, J. Han, et al, Use of THM-PY-GC/MS technique to characterize complex, multilayered Chinese lacquer, J. Anal. Appl. Pyrolysis 140 (2019) 339-348.

[211] S. Wei, V. Pintus, V. Pitthard, M. Schreiner, G. Song, Analytical characterization of lacquer objects excavated from a Chu tomb in China, J. Archaeol. Sci. 38 (2011) 2667-2674.

[212] A.S. Le Hô, M. Regert, O. Marescot, C. Duhamel, J. Langlois, T. Miyakoshi, et al., Molecular criteria for discriminating museum Asian lacquerware from different vegetal origins by pyrolysis gas chromatography/mass spectrometry, Anal. Chim. Acta 710 (2012) 9-16.

[213] A.M. Committee, A. No, Analytical pyrolysis in cultural heritage, Anal. Methods. 10 (2018) 5463-5467.

[214] M. Schilling, M. Bouchard, H. Khanjian, T. Learner, A. Phenix, R. Rivenc, Application of chemical and thermal analysis methods for studying cellulose ester plastics, Acc. Chem. Res. 43 (2010) 888-896.

[215] D. Pinna, M. Galeotti, A. Rizzo, E. Cantisani, G. Sciutto, M. Zangheri, et al., A follow-up on the analytical study of discolouration of the marble statues of Orsanmichele in Florence, Environ. Sci. Pollut. Res. 24 (2017) $334-352$.

[216] J. Dorscheid, J. Köhler, M. de Vlam, I. Joosten, H. van Keulen, P. van Duin, Dutch inlaid aventurine decoration: study, analysis, and conservation, Stud. Conserv. 3630 (2019) 1-10.

[217] S. Dallongeville, N. Garnier, C. Rolando, C. Tokarski, Proteins in art, archaeology, and paleontology: from detection to identification, Chem. Rev. 116 (2016) 2-79.

[218] L. Decq, Y. Jones, D. Steyaert, V. Cattersel, C. Indekeu, E. Van Binnebeke, et al. Black lacquered papier-mâché and turned wooden furniture: unravelling the art history, technology and chemistry of the 19th-century Japanning industry, Stud. Conserv. 64 (2019) S31-S44.

[219] R. Nakagawa, S. Nakai, T. Miyakoshi, T. Honda, Materials and provenance determination of lacquerware from the Ryukyu Kingdom period by pyrolysis-gas chromatography/mass spectrometry and $87 \mathrm{Sr} / 86 \mathrm{Sr}$ isotope ratio, J. Archaeol. Sci. Reports. 25 (2019) 72-76.

[220] C.E. Rogge, K. Lough, Fluorescence fails: the color of UVA-induced visible fluorescence of tintype varnishes does not discriminate between varnish materials, Top. Photogr. Preserv. 15 (2013) 239-248.

[221] K. Sutherland, Bleached shellac picture varnishes: characterization and case studies, J. Inst. Conserv. 33 (2010) 129-145. 
[222] L. Decq, E. Abatih, H. Van Keulen, V. Leyman, V. Cattersel, D. Steyaert, et al., Nontargeted pattern recognition in the search for pyrolysis gas chromatography/mass spectrometry resin markers in historic lacquered objects, Anal. Chem. 91 (2019) 7131-7138.

[223] D. Teetaert, M. Boudin, S. Saverwyns, P. Crombé, Food and soot: organic residues on outer pottery surfaces, Radiocarbon 59 (2017) 1609-1621.

[224] J. Kaal, O. Lantes-Suárez, A. Martínez Cortizas, B. Prieto, M.P. Prieto Martínez, How useful is pyrolysis-GC/MS for the assessment of molecular properties of organic matter in archaeological pottery matrix? An exploratory case study from north-west Spain, Archaeometry 56 (2014) 187-207.

[225] D. Cauzzi, G. Chiavari, S. Montalbani, D. Melucci, D. Cam, H. Ling, Spectroscopic and chromatographic studies of sculptural polychromy in the Zhongshan Grottoes (R.P.C.), J. Cult. Herit. 14 (2013) 70-75.

[226] C.E. Rogge, The varnished truth: the recipes and reality of tintype coatings, J. Cult. Herit. 15 (2014) 57-63.

[227] X. Ma, Y. Shi, H. Khanjian, M. Schilling, M. Li, H. Fang, et al., Characterization of early imperial lacquerware from the luozhuang han tomb, China, Archaeometry 59 (2017) 121-132.

[228] M. Vermeulen, J. Sanyova, K. Janssens, Identification of artificial orpiment in the interior decorations of the Japanese tower in Laeken, Brussels, Belgium, Herit. Sci. 3 (2015) 1-9.

[229] O. Katsibiri, R.F. Howe, Microscopic, mass spectrometric and spectroscopic characterisation of the mordants used for gilding on wall paintings from three post-Byzantine monasteries in Thessalia, Greece, Microchem. J. 94 (2010) 83-89.

[230] S. Wei, V. Pintus, M. Schreiner, A comparison study of alkyd resin used in art works by Py-GC/MS and GC/MS: the influence of aging, J. Anal. Appl. Pyrolysis 104 (2013) 441-447.

[231] E.Z.F.C. Izzo, E. Balliana, F. Pinton, A preliminary study of the composition of commercial oil, acrylic and vinyl paints and their behaviour after accelerated ageing conditions, Conserv. Sci. Cult. Herit. 14 (2014) 353-369.

[232] R. Ploeger, O. Chiantore, Characterization and stability issues of artists' alkyd paints, Smithsonian Contrib. Mus. Conserv. 3 (2012) 89-95.

[233] R.L. Cook, T.S. Bianchi, R.D. DeLaune, K.R. Reddy, C.J. Richardson, J.P. Megonigal, Characterization of wetland soil organic matter, 2014, pp. 289-316.

[234] B.W. Murphy, Impact of soil organic matter on soil properties - a review with emphasis on Australian soils, Soil Res. 53 (2015) 605-635.

[235] J. Routh, T.S. Bianchi, J.A. Hutchings, P. Kuhry, R.K. Ranjan, Organic carbon characteristics in Swedish forest soil trace post-depositional carbon dynamics, Eur. J. Soil Sci. 67 (2016) 492-503.

[236] D. Elhottová, A. Koubová, M. Šimek, T. Cajthaml, J. Jirout, J. Esperschuetz, et al., Changes in soil microbial communities as affected by intensive cattle husbandry, Appl. Soil Ecol. 58 (2012) 56-65.

[237] N. Weiss, J. Kaal, Characterization of labile organic matter in Pleistocene permafrost (NE Siberia), using Thermally assisted Hydrolysis and Methylation (THM-GC-MS), Soil Biol. Biochem. 117 (2018) 203-213.

[238] Y. Yustiawati, K. Kihara, H. Sazawa, M. Kuramitz, T. Kurasaki, Saito, et al. Effects of peat fires on the characteristics of humic acid extracted from peat soil in Central Kalimantan, Indonesia, Environ. Sci. Pollut. Res. 22 (2015) 2384-2395.

[239] C.S. Lee, T.M. Sung, H.S. Kim, C.H. Jeon, Classification of forensic soil evidences by application of THM-PyGC/MS and multivariate analysis, J. Anal. Appl. Pyrolysis 96 (2012) 33-42.

[240] M. Nakakuni, C. Dairiki, G. Kaur, S. Yamamoto, Stanol to sterol ratios in late Quaternary sediments from southern California: an indicator for continuous variability of the oxygen minimum zone, Org, Geochem. (Tokyo. 1967) 111 (2017) 126-135.

[241] S. Drouin, M. Boussafir, J.L. Robert, P. Alberic, A. Durand, Carboxylic acid sorption on synthetic clays in sea water: in vitro experiments and implications for organo-clay behaviour under marine conditions, Org. Geochem. 41 (2010) 192-199.

[242] F. Baudin, J.R. Disnar, P. Martinez, B. Dennielou, Distribution of the organic matter in the channel-levees systems of the Congo mud-rich deep-sea fan (West Africa). Implication for deep offshore petroleum source rocks and global carbon cycle, Mar. Petrol. Geol. 27 (2010) 995-1010.

[243] M. Nakakuni, J. Kitano, H. Uemura, S. Yamamoto, Modern sediment records of stanol to sterol ratios in Lake Suigetsu, Japan: an indicator of variable lacustrine redox conditions, Org. Geochem. 119 (2018) 59-71.

[244] J.A. Baldock, J. Sanderman, L.M. MacDonald, A. Puccini, B. Hawke, S. Szarvas, et al., Quantifying the allocation of soil organic carbon to biologically significant fractions, Soil Res. 51 (2013) 561-576.

[245] M. Thevenot, M.F. Dignac, C. Rumpel, Fate of lignins in soils: a review, Soil Biol. Biochem. 42 (2010) 1200-1211.

[246] D.V. Guimarães, M.I.S. Gonzaga, T.O. da Silva, T.L. da Silva, N. da Silva Dias, M.I.S. Matias, Soil organic matter pools and carbon fractions in soil unde different land uses, Soil Tillage Res. 126 (2013) 177-182.

[247] E.Y. Swain, Molecular characterization of terrestrial organic carbon in some organic-rich soils in the Northern Latitudes, Newcastle University, 2013.

[248] H. Ohtani, K. Takeuchi, Y. Iiguni, A. Kaneko, M. Kiura, H. Momose, End group analysis of styrene-butyl acrylate copolymers initiated with benzoyl peroxide by stepwise chemolysis-pyrolysis gas chromatography, J. Anal. Appl. Pyrolysis 124 (2017) 677-681.

[249] M. Blazsó, J. Bozi, Ammonium Y zeolite applied as a thermochemolysis reagent for identification of polyethers and polyesters, J. Chromatogr., A 1271 (2013) 217-220.
[250] R. Spaccini, D. Todisco, M. Drosos, A. Nebbioso, A. Piccolo, Decomposition of bio-degradable plastic polymer in a real on-farm composting process, Chem. Biol. Technol. Agric. 3 (2016) 1-12.

[251] A. Hosaka, C. Watanabe, N. Teramae, H. Ohtani, Development of a new micro reaction sampler for pyrolysis-GC/MS system facilitating on-line analytical chemolysis of intractable condensation polymers, J. Anal. Appl. Pyrolysis 106 (2014) 160-163.

[252] C. Schwarzinger, I. Hintersteiner, B. Schwarzinger, W. Buchberger, B. Moser, Analytical pyrolysis in the determination of the aging of polyethylene, J. Anal. Appl. Pyrolysis 113 (2015) 315-322.

[253] S. Baidurah, S. Takada, K. Shimizu, K. Yasue, S. Arimoto, Y. Ishida, et al., Evaluation of biodegradation behavior of poly(butylene succinate-cobutylene adipate) with lowered crystallinity by thermally assisted hydrolysis and methylation-gas chromatography, Int. J. Polym. Anal. Char. 17 (2012) 29-37.

[254] S. Baidurah, S. Takada, K. Shimizu, Y. Ishida, T. Yamane, H. Ohtani, Evaluation of biodegradation behavior of poly(butylene succinate-co- butylene adipate) with lowered crystallinity by thermally assisted hydrolysis and methylationgas chromatography, J. Anal. Appl. Pyrolysis 103 (2013) 73-77.

[255] S. Baidurah, P. Murugan, L. Joyyi, J. Fukuda, M. Yamada, K. Sudesh, et al., Validation of thermally assisted hydrolysis and methylation-gas chromatography for rapid and direct compositional analysis of poly(3hydroxybutyrate-co-3-hydroxyhexanoate) in whole bacterial cells, J. Chromatogr., A 1471 (2016) 186-191.

[256] S. Baidurah, P. Murugan, K.Y. Sen, Y. Furuyama, M. Nonome, K. Sudesh, et al., Evaluation of soil burial biodegradation behavior of poly(3-hydroxybutyrateco-3-hydroxyhexanoate) on the basis of change in copolymer composition monitored by thermally assisted hydrolysis and methylation-gas chromatography, J. Anal. Appl. Pyrolysis 137 (2019) 146-150.

[257] M. David, N.Y. Musadji, J. Labanowski, R. Sternberg, C. Geffroy-Rodier, Pilot for validation of online pretreatments for analyses of organics by gas chromatography-mass spectrometry: application to space research, Anal. Chem. 88 (2016) 5137-5144.

[258] J.P. Grotzinger, J. Crisp, A.R. Vasavada, R.C. Anderson, C.J. Baker, R. Barry, et al., Mars Science Laboratory Mission and Science Investigation, 2012.

[259] A. Buch, R. Sternberg, C. Szopa, C. Freissinet, C. Garnier, E.J. Bekri, et al., Development of a gas chromatography compatible Sample Processing System (SPS) for the in-situ analysis of refractory organic matter in martian soil: preliminary results, Adv. Space Res. 43 (2009) 143-151.

[260] C. Freissinet, D.P. Glavin, A. Buch, C. Szopa, S. Kashyap, H.B. Franz, et al., First in situ wet chemistry experiment on Mars using the SAM instrument: MTBSTFA derivatization on a Martian Mudstone, in: 46th LPSC Lunar Planet. Sci. Conf., 2015.

[261] M. Millan, C. Szopa, A. Buch, P. Coll, D.P. Glavin, C. Freissinet, et al., In situ analysis of martian regolith with the SAM experiment during the first mars year of the MSL mission: identification of organic molecules by gas chromatography from laboratory measurements, Planet, Space Sci 129 (2016) $88-102$.

[262] L.A. Leshin, P.R. Mahaffy, C.R. Webster, M. Cabane, P. Coll, P.G. Conrad, et al., Volatile, isotope, and organic analysis of martian fines with the Mars curiosity rover, Science 341 (80) (2013) 1238937.

[263] D.W. Ming, P.D. Archer, D.P. Glavin, J.L. Eigenbrode, H.B. Franz, B. Sutter, et al., Volatile and organic compositions of sedimentary rocks in yellowknife Bays, Gale crater, mars, Science 343 (2014) 1-10.

[264] C. Szopa, C. Freissinet, D.P. Glavin, M. Millan, A. Buch, H.B. Franz, et al., First detections of dichlorobenzene isomers and trichloromethylpropane from organic matter indigenous to mars mudstone in gale crater, mars: results from the sample analysis at mars instrument onboard the curiosity rover, Astrobiology 20 (2019) 1-15.

[265] C. Freissinet, A. Buch, R. Sternberg, C. Szopa, C. Geffroy-Rodier, C. Jelinek, et al., Search for evidence of life in space: analysis of enantiomeric organic molecules by $\mathrm{N}, \mathrm{N}$-dimethylformamide dimethylacetal derivative dependant Gas Chromatography-Mass Spectrometry, J. Chromatogr., A 1217 (2010) $731-740$.

[266] A. Buch, M. Morisson, C. Szopa, F. Raulin, M. Stambouli, TMAH thermochemolysis of a Martian regolith simulant: optimization of an analytical method for the detection of trace organic matter by the MOMA-Pyr-GC-MS experiment onboard the ExoMars-2020 Rover, Lunar Planet. Sci. XLVIII (2017).

[267] C. Geffroy-Rodier, L. Grasset, R. Sternberg, A. Buch, A. Amblès, Thermochemolysis in search for organics in extraterrestrial environments, J. Anal. Appl. Pyrolysis 85 (2009) 454-459.

[268] A.J. Williams, J. Eigenbrode, M. Floyd, M.B. Wilhelm, S. O'Reilly, S.S. Johnson, et al., Recovery of fatty acids from mineralogic mars analogs by TMAH thermochemolysis for the sample analysis at mars wet chemistry experiment on the curiosity rover, Astrobiology 19 (2019) 522-546.

[269] J.L. Vago, F. Westall, L.S. Pasteur Instrument Teams, A.J. Coates, R. Jaumann, O. Korablev, et al., Habitability on early mars and the search for biosignatures with the ExoMars rover, Astrobiology 17 (2017) 471-510.

[270] A. Buch, I. Belmahdi, C. Szopa, C. Freissinet, D.P. Glavin, M. Millan, et al., Role of the Tenax $(\mathbb{R}$ adsorbent in the interpretation of the EGA and GC-MS analyses performed with the sample analysis at Mars in Gale Crater, J. Geophys. Res. Planets. 124 (2019) 2819-2851.

[271] B.M. Scholz-Böttcher, A. Nissenbaum, J. Rullkötter, An 18th century medication "Mumia vera aegyptica" - fake or authentic? Org. Geochem. 65 (2013) $1-18$. 
[272] A. Sun, Z. Lai, M. Zhao, L. Mu, X. Hu, Native nanodiscs from blood inhibit pulmonary fibrosis, Biomaterials 192 (2019) 51-61.

[273] R.N. Qureshi, E. Kaal, H.G. Janssen, P.J. Schoenmakers, W.T. Kok, Determination of cholesterol and triglycerides in serum lipoproteins using flow fieldflow fractionation coupled to gas chromatography-mass spectrometry, Anal. Chim. Acta 706 (2011) 361-366.

[274] J. Lodowska, D. Wolny, S. Kurkiewicz, L. Węglarz, The pyrolytic profile of lyophilized and deep-frozen compact part of the human bone, Sci. World J. 2012 (2012) 1-7. https://doi.org/10.1100/2012/162406.

[275] Y. Lu, P.B. Harrington, Classification of bacteria by simultaneous methylation-solid phase microextraction and gas chromatography/mass spectrometry analysis of fatty acid methyl esters, Anal. Bioanal. Chem. 397 (2010) 2959-2966.

[276] N.A. Dang, A.H.J. Kolk, S. Kuijper, H.G. Janssen, G. Vivo-Truyols, The identification of biomarkers differentiating Mycobacterium tuberculosis and nontuberculous mycobacteria via thermally assisted hydrolysis and methylation gas chromatography-mass spectrometry and chemometrics, Metabolomics 9 (2013) 1274-1285.

[277] S.C. Nicoara, D.E. Minnikin, O.C.Y. Lee, D.M. O'Sullivan, R. McNerney, C.T. Pillinger, et al., Development and optimization of a gas chromatography/ mass spectrometry method for the analysis of thermochemolytic degradation products of phthiocerol dimycocerosate waxes found in Mycobacterium tuberculosis, Rapid Commun. Mass Spectrom. 27 (2013) 2374-2382.

[278] E. Fid, Determinative chromatographic separations, in: Method $8000 \mathrm{C}$ Determ. Chromatogr, 2003.

[279] A.W.R. Seddon, M. Jokerud, T. Barth, H.J.B. Birks, L.C. Krüger, V. Vandvik, et al., Improved quantification of UV-B absorbing compounds in Pinus sylvestris L. pollen grains using an internal standard methodology, Rev. Palaeobot. Palynol. 247 (2017) 97-104.

[280] C. Estournel-Pelardy, F. Delarue, L. Grasset, F. Laggoun-Défarge, A. Amblès, Tetramethylammonium hydroxide thermochemolysis for the analysis of cellulose and free carbohydrates in a peat bog, J. Anal. Appl. Pyrolysis 92 (2011) 401-406.

[281] W.C. Kossa, J. MacGee, S. Ramachandran, A.J. Webber, Pyrolytic methylation/ gas chromatography: a short review, J. Chromatogr. Sci. 17 (1979) 177-187.

[282] J.M. Challinor, Review: the development and applications of thermally assisted hydrolysis and methylation reactions, J. Anal. Appl. Pyrolysis 61 (2001) 3-34.

[283] J. Templier, N. Gallois, S. Derenne, Analytical TMAH pyrolysis of dipeptides: formation of new complex cyclic compounds related to the presence of the peptide bond, J. Anal. Appl. Pyrolysis 104 (2013) 684-694.

[284] W.K. Musker, Nitrogen yields. III. Explosive decomposition of tetramethylammonium amide, J. Org. Chem. 32 (2005) 3189-3191.

[285] C.S. Macomber, J.M. Boncella, B.S. Pivovar, J.A. Rau, Decomposition pathways of an alkaline fuel cell membrane material component via evolved gas analysis, J. Therm. Anal. Calorim. 93 (2008) 225-229.

[286] H. Finkbeiner, Chelation as a driving force in organic reactions.1 A generics synthesis of amino acids by the carboxylation and alkylation of 3phenylhydantoin, J. Am. Chem. Soc. 86 (1964) 961-962.

[287] S. Chempath, B.R. Einsla, L.R. Pratt, C.S. Macomber, J.M. Boncella, J.A. Rau, et al., Mechanism of tetraalkylammonium headgroup degradation in alkaline fuel cell membranes, J. Phys. Chem. C 112 (2008) 3179-3182.

[288] G. Surpateanu, J.P. Catteau, P. Karafiloglou, A. Lablache-Combier, Structure and reactivity of cycloimmonium ylides, Tetrahedron 32 (1976) 2647-2663.

[289] S. Chempath, J.M. Boncella, L.R. Pratt, N. Henson, B.S. Pivovar, Density functional theory study of degradation of tetraalkylammonium hydroxides, J. Phys. Chem. C 114 (2010) 11977-11983.

[290] H. Long, B.S. Pivovar, Hydroxide degradation pathways for substituted benzyltrimethyl ammonium: a DFT Study, J. Phys. Chem. C 116 (2012) 9419-9426.

[291] J.B. Edson, C.S. Macomber, B.S. Pivovar, J.M. Boncella, Hydroxide based decomposition pathways of alkyltrimethylammonium cations, J. Membr. Sci. 399-400 (2012) 49-59.

[292] C.W. Wang, C. Liang, Oxidative degradation of TMAH solution with UV persulfate activation, Chem. Eng. J. 254 (2014) 472-478.

[293] Y. Wang, Z. Zhang, C. Jiang, T. Xu, Electrodialysis process for the recycling and concentrating of tetramethylammonium hydroxide (TMAH) from photoresist developer wastewater, Ind. Eng. Chem. Res. 52 (2013) 18356-18361.

[294] M. Mizumoto, E. Shimokita, T. Ona, T. Seino, Y. Ishida, H. Ohtani, Rapid and direct characterization of total fatty acids in wood by thermochemolysis-gas chromatography-flame ionization detector/mass spectrometry with tetrabutylammonium hydroxide, J. Anal. Appl. Pyrolysis 87 (2010) 163-167.

[295] M. Gómez-Brandón, M. Lores, J. Domínguez, A new combination of extraction and derivatization methods that reduces the complexity and preparation time in determining phospholipid fatty acids in solid environmental samples, Bioresour. Technol. 101 (2010) 1348-1354.

[296] C. Biache, A.E. Navarro Frómeta, F. Czechowski, Y. Lu, R.P. Philp, Thiosteranes in samples impacted by fecal materials and their potential use as marker of sewage input, Environ. Pollut. 196 (2015) 268-275.

[297] D. Válková, L. Grasset, A. Amblès, Molecular compounds generated by ruthenium tetroxide oxidation and preparative off line thermochemolysis of lignite humic acids from South Moravia: implications for molecular structure, Fuel 88 (2009) 2113-2121.

[298] G. Qi, D. Yue, M. Fukushima, S. Fukuchi, Y. Nie, Enhanced humification by carbonated basic oxygen furnace steel slag - I. Characterization of humic-like acids produced from humic precursors, Bioresour. Technol. 104 (2012) 497-502.

[299] R. Ploeger, A. Shugar, G.D. Smith, V.J. Chen, Late 19th century accounts of Indian yellow: the analysis of samples from the royal botanic gardens, kew, dye, Pigment 160 (2019) 418-431.

[300] B. Chefetz, J. Tarchitzky, A.P. Deshmukh, P.G. Hatcher, Y. Chen, Structural characterization of soil organic matter and humic acids in particlesize fractions of an agricultural soil, Soil Sci. Soc. Am. J. 66 (2002) $129-141$.

[301] S. Saverwyns, M. Vermeulen, E. Van Binnebeke, Preliminary investigation of the chemical composition of European lacquers using pyrolysis gas chromatography-mass spectrometry, e-Preservation Sci. 11 (2014) 64-75.

[302] K.I. Kuroda, A. Nakagawa-Izumi, Tetramethylammonium hydroxide (TMAH) thermochemolysis of lignin: behavior of 4-O-etherified cinnamyl alcohols and aldehydes, J. Agric. Food Chem. 53 (2005) 8859-8865.

[303] C. Riedo, D. Scalarone, O. Chiantore, Pyrolysis-GC/MS for the identification of macromolecular components in historical recipes, Anal. Bioanal. Chem. 401 (2011) 1761-1769.

[304] C.J. Tsai, C.C. Liu, L.B. Hung, B.S. Pan, TMAH-catalyzed transesterification of EPA and DHA in encapsulated fish oil products, J. Am. Oil Chem. Soc. 89 (2012) 9-16.

[305] D.T. Mannion, A. Furey, K.N. Kilcawley, Comparison and validation of 2 analytical methods for the determination of free fatty acids in dairy products by gas chromatography with flame ionization detection, J. Dairy Sci. 99 (2016) 5047-5063.

[306] H. Kano, T. Okamoto, S. Kitagawa, Y. Iiguni, H. Ohtani, H. Ito, et al., A novel analytical pyrolysis device applicable for measurements of less volatile pyrolyzates, J. Anal. Appl. Pyrolysis 113 (2015) 165-173.

[307] I.C.A. Sandu, A. Candeias, K.J. van den Berg, E.G. Sandbakken, E.S. Tveit, H. van Keulen, Multi technique and multiscale approaches to the study of ancient and modern art objects on wooden and canvas support, Phys. Sci. Rev. 4 (2019) $1-31$.

[308] I. Pastorova, K.J. Van Der Berg, J.J. Boon, J.W. Verhoeven, Analysis of oxidised diterpenoid acids using thermally assisted methylation with TMAH, J. Anal. Appl. Pyrolysis 43 (1997) 41-57.

[309] C. Granzotto, K. Sutherland, J. Arslanoglu, G.A. Ferguson, Discrimination of Acacia gums by MALDI-TOF MS: applications to micro-samples from works of art, Microchem. J. 144 (2019) 229-241.

[310] I.D. Van Der Werf, C.D. Calvano, R. Laviano, A. Simonetti, L. Sabbatini, Multitechnique chemical characterisation of a 12-13th-century painted Crucifix, Microchem, J 106 (2013) 87-94.

[311] C.D. Calvano, I.D. van der Werf, F. Palmisano, L. Sabbatini, Revealing the composition of organic materials in polychrome works of art: the role of mass spectrometry-based techniques, Anal. Bioanal. Chem. 408 (2016) 6957-6981.

[312] J.V. Hogancamp, B. Sutter, R.V. Morris, P.D. Archer, D.W. Ming, E.B. Rampe, et al., Chlorate/Fe-bearing phase mixtures as a possible source of oxygen and chlorine detected by the sample analysis at mars (SAM) instrument in gale crater, mars, J. Geophys. Res. Planets. 123 (2018) 2920-2938.

[313] E. Pagliano, B. Campanella, A. D'Ulivo, Z. Mester, Derivatization chemistries for the determination of inorganic anions and structurally related compounds by gas chromatography - a review, Anal. Chim. Acta 1025 (2018) $12-40$.

[314] M. Miyamoto, K. Mabuchi, J. Kamada, Y. Hirota, Y. Oumi, N. Nishiyama, et al., para-Selectivity of silicalite-1 coated MFI type galloaluminosilicate in aromatization of light alkanes, J. Porous Mater. 22 (2015) 769-778.

[315] A. Khosravanipour Mostafazadeh, O. Solomatnikova, P. Drogui, R. Dayal Tyagi, A review of recent research and developments in fast pyrolysis and bio-oil upgrading, Biomass Conv. Bioref. 8 (2018) 739-773.

[316] X. Yu, C. Liu, Y. Guo, T. Deng, Speciation analysis of trace arsenic, mercury, selenium and antimony in environmental and biological samples based on hyphenated techniques, Molecules 24 (2019) 926.

[317] H. Matsuzaki, Y.S. Tsuchiya, Y. Muramatsu, Y. Maejima, Y. Miyairi, K. Kato Comparison of Depth Profiles of 129 I and 14 C Concentration in the surface layer of soil collected from northeasterm Japan, Radiocarbon 52 (2010) 1487-1497.

[318] S.S.F. Al-Khattaf, A.A. Al-Absi, Conversion of Arabian light crude oil to light olefins via catalytic and thermal cracking, Energy Fuels 32 (2018) $8705-8714$.

[319] T.S. Peretyazhko, B. Sutter, R.V. Morris, D.G. Agresti, L. Le, D.W. Ming, Fe/Mg smectite formation under acidic conditions on early Mars, Geochem. Cosmochim. Acta 173 (2016) 37-49.

[320] K. Gołąbek, K.A. Tarach, K. Góra-Marek, Xylenes transformation over zeolites ZSM-5 ruled by acidic properties, Spectrochim. Acta Part A Mol. Biomol. Spectrosc. 192 (2018) 361-367.

[321] A. Quéro, R. Molinié, D. Mathiron, B. Thiombiano, J.X. Fontaine, D. Brancourt et al., Metabolite profiling of developing Camelina sativa seeds, Metabolomics 12 (2016) 1-14.

[322] E.V. Abakumov, T. Cajthaml, J. Brus, J. Frouz, Humus accumulation, humification, and humic acid composition in soils of two post-mining chronosequences after coal mining, J. Soils Sediments 13 (2013) 491-500.

[323] L. Nieto, J. Jiménez-Barbero, A.T. Martínez, J. Rencoret, A. Gutiérrez, J.C. del Río, White and brown rot decay as two models for biotechnological processing of wood: structural analysis by 2D NMR and analytical pyrolysis, Oxidative Enzym. as Sustain. Ind. Biocatal. (2010) 1-6. 
[324] L. Xiao, Y. Li, Y. Liao, H. Ma, J. Wu, Y. Zhang, et al., Bioconversion of lignite humic acid by white-rot fungi and characterization of products, 3 Biotech 8 (2018) 258

[325] K.I. Kuroda, T. Ashitani, K. Fujita, Tetramethylammonium hydroxide (TMAH) thermochemolysis of lignin: formation of (E)-5-formyl-2,3,3',4'-tetramethoxystilbene and its origins, J. Anal. Appl. Pyrolysis 89 (2010) 233-238.

[326] A. Gomiero, K.B. Øysæd, T. Agustsson, N. van Hoytema, T. van Thiel, F. Grati, First record of characterization, concentration and distribution of microplastics in coastal sediments of an urban fjord in south west Norway using a thermal degradation method, Chemosphere 227 (2019) 705-714.

[327] F.C. Izzo, A. Carrieri, G. Bartolozzi, H. van Keulen, I. Lorenzon, E. Balliana, et al., Elucidating the composition and the state of conservation of nitrocellulose-based animation cells by means of non-invasive and microdestructive techniques, J. Cult. Herit. 35 (2019) 254-262.

[328] S. Chang, K.Y.A. Lin, C. Lu, Efficient adsorptive removal of Tetramethylammonium hydroxide (TMAH) from water using graphene oxide, Separ Purif. Technol. 133 (2014) 99-107.

[329] M. Collard, B. Teychené, L. Lemée, Comparison of three different wastewater sludge and their respective drying processes: solar, thermal and reed beds impact on organic matter characteristics, J. Environ. Manag. 203 (2017) $760-767$.

[330] S. Aveni, M.B. Failla, A. Gatti, L. Mannina, T. Poli, A japanned telescope from cavour castle in santena: study and conservation treatment of an eighteenthcentury scientific instrument, Stud. Conserv. 64 (2019) S147-S153.

[331] H. Szczepanowska, R. Ploeger, The chemical analysis of Southeast Asian lacquers collected from forests and workshops, J. Cult. Herit. 40 (2019) 215-225.

[332] J. Kotulová, D. Starek, M. Havelcová, H. Pálková, Amber and organic matter from the late Oligocene deep-water deposits of the central western carpathians (Orava-Podhale basin), Int. J. Coal Geol. 207 (2019) 96-109.

[333] K. Helwig, É. Forest, A. Turcotte, W. Baker, N.E. Binnie, E. Moffatt, et al., The formation of calcium fatty acid salts in oil paint: two case studies, 2019, pp. 297-311.

[334] M. Kirpluks, E. Vanags, A. Abolins, A. Fridrihsone, U. Cabulis, Chemo-enzymatic oxidation of tall oil fatty acids as a precursor for further polyol production, J. Clean. Prod. 215 (2019) 390-398.

[335] S. El-Guendouz, B. Lyoussi, J.P. Lourenç, A.M. Rosa da Costa, M.G. Miguel, C. Barrocas Dias, et al., Magnetite nanoparticles functionalized with propolis against methicillin resistant strains of Staphylococcus aureus, J. Taiwan Inst. Chem. Eng. 102 (2019) 25-33.

[336] P.G. Hammer, D.R. Locke, A.S. Burton, M.P. Callahan, Thermal Studies of Smmonium Cyanide Reactions: A Model for Thermal Alteration of Prebiotic Compounds in Meteorite Parent Bodies, 2017.

[337] R.A. Parildar, A.A.B. Ibik, Characterization of tertiary amine and epoxy functional all-acrylic coating system, Prog. Org. Coating 76 (2013) 955-958.

[338] J. Zhang, C. Yip, C. Xia, Y. Liang, Evaluation of methane release from coals from the San Juan basin and Powder River basin, Fuel 244 (2019) 388-394.

[339] S.I. Yamasaki, A. Takeda, T. Watanabe, K. Tagami, S. Uchida, H. Takata, et al. Bromine and iodine in Japanese soils determined with polarizing energy dispersive X-ray fluorescence spectrometry, Soil Sci. Plant Nutr. 61 (2015 $751-760$.

[340] J. Zhang, K. Anderson, D. Britt, Y. Liang, Sustaining biogenic methane release from Illinois coal in a fermentor for one year, Fuel 227 (2018) 27-34.

[341] F. Beckett, A. Holden, G.D. Smith, Seeing the light: research, conservation and exhibition of a 1980s daylight fluorescent painted leather jacket designed by Sprouse and painted by Castronovo, J. Am. Inst. Conserv. 58 (2019) 233-247.

[342] C. Canevali, P. Gentile, M. Orlandi, F. Modugno, J.J. Lucejko, M.P. Colombini, et al., A multi-analytical approach for the characterization of powders from the Pompeii archaeological site, Anal. Bioanal. Chem. 401 (2011) 1801-1814.

[343] A. Rizzo, N. Shibayama, D.P. Kirby, A multi-analytical approach for the identification of aloe as a colorant in oil-resin varnishes, Anal. Bioanal. Chem. 399 (2011) 3093-3107.
[344] A. Le Gac, R. Estrompa, J.C. Frade, S. Pessanha, T.I. Madeira, A. Cardoso, et al., Multianalytical approach for the authenticity of an eighteenth-century Pascal Taskin harpsichord, J. Anal. At. Spectrom. 27 (2012) 626-643.

[345] C. Riedo, D. Scalarone, O. Chiantore, Multivariate analysis of pyrolysis-GC/MS data for identification of polysaccharide binding media, Anal. Methods. 5 (2013) 4060-4067.

[346] V. Pitthard, S. Stanek, M. Griesser, C. Jordan, S. Miklin-Kniefacz, R. Miklin, The technical investigation of an eighteenth-century Chinese imperial carved lacquer screen and its role in developing an appropriate conservation treatment, Stud. Conserv. 61 (2016) 97-108.

[347] U. Körber, M.R. Schilling, C.B. Dias, L. Dias, Simplified Chinese lacquer techniques and Nanban style decoration on Luso-Asian objects from the late sixteenth or early seventeenth centuries, Stud. Conserv. 61 (2016) 68-84.

[348] M. Kokkori, M.O. Hubert, N. Balcar, G. Barabant, K. Sutherland, F. Casadio, Gloss paints in late paintings by Francis Picabia: a multi-analytical study, Appl. Phys. Mater. Sci. Process 122 (2016) 1-11.

[349] M.A. Yandrisevits, P. Londero, F. Carò, A. Rizzo, C. Cappuccini, Wavelengthdependent absorption and scattering effects on laser cleaning of a corroded iron alloy European scale armor, Lasers Conserv. Artworks XI (2017) 27-45.

[350] B. Klempan, K. Helwig, F. Colivicchi, Examination and analysis of Etruscan wall paintings at Caere, Italy, Archaeometry. 59 (2017) 1082-1094.

[351] Y. Song, F. Gao, A. Nevin, J. Guo, X. Zhou, S. Wei, et al, A technical study of the materials and manufacturing process used in the Gallery wall paintings from the Jokhang temple, Tibet, Herit. Sci. 6 (2018) 1-13.

[352] L. Wei, W. Chen, G. Jin, Z. Guo, Y. Wang, B. Kang, et al., Scientific analysis of tie Luo, a qing dynasty calligraphy artifact in the palace museum, beijing, China, Herit. Sci. 6 (2018) 1-14.

[353] A.K. Hansen, M.B. Christiansen, J. Sanyova, K.P. Simonsen, Analysis of poul gernes' painted folding doors at herlev hospital, Herit. Sci. 6 (2018) 1-8.

[354] J. Park, M.R. Schilling, H. Khanjian, J. Lee, Stratigraphic examination of a Korean lacquered wooden coffin sample by Pyrolysis/GC/MS, Chromatographia 81 (2018) 1685-1694.

[355] H. Han, S. Wei, J. Yang, L. Guan, W. Li, Characterization of the residues in Han Dynasty bronze lamps by pyrolysis-gas chromatography-mass spectrometry, Herit. Sci. 7 (2019) 1-9.

[356] O.O. Sonibare, R.J. Huang, D.E. Jacob, Y. Nie, E. Kleine-Benne, T. Hoffmann, et al., Terpenoid composition and chemotaxonomic aspects of Miocene amber from the Koroglu Mountains, Turkey, J. Anal. Appl. Pyrolysis 105 (2014) $100-107$.

[357] C.J. Saunders, M. Gao, R. Jaffé, Environmental assessment of vegetation and hydrological conditions in Everglades freshwater marshes using multiple geochemical proxies, Aquat. Sci. 77 (2015) 271-291.

[358] S. Nishimura, N. Maie, M. Baba, T. Sudo, T. Sugiura, E. Shima, Changes in the quality of chromophoric dissolved organic matter leached from senescent leaf litter during the early decomposition, J. Environ. Qual. 41 (2012) 823-833.

[359] K.P. Mosse, T. Vincent Verheyen, A.J. Cruickshank, A.F. Patti, T.R. Cavagnaro, Thermochemolysis of winery wastewater particulates - molecular structural implications for water reuse, J. Anal. Appl. Pyrolysis 97 (2012) 164-170.

[360] F. Orange, J.R. Disnar, P. Gautret, F. Westall, N. Bienvenu, N. Lottier, et al. Preservation and evolution of organic matter during experimental fossilisation of the hyperthermophilic Archaea methanocaldococcus jannaschii, Orig. Life Evol. Biosph. 42 (2012) 587-609.

[361] I. Deniau, J.R. Disnar, F. Baudin, J.P. Houzay, Characterization of organic matter in the Oligocene (Chattian) turbiditic fine grained deposits, offshore Angola, Org. Geochem. 41 (2010) 135-145.

[362] C. Crestini, M. Crucianelli, M. Orlandi, R. Saladino, Oxidative strategies in lignin chemistry: a new environmental friendly approach for the functionalisation of lignin and lignocellulosic fibers, Catal. Today 156 (2010) 8-22.

[363] R. Vanholme, B. Demedts, K. Morreel, J. Ralph, W. Boerjan, Lignin biosynthesis and structure, Plant Physiol. 153 (2010) 895-905. 